\title{
MAN, SOCIETY, POLITICS: TOPICAL CHALLENGES OF THE MODERNITY
}

\author{
Collective monograph
}

$$
\underbrace{1256}_{\text {LIHA-PRES }} \begin{aligned}
& \text { Lviv-Toruń } \\
& \text { Liha-Pres } \\
& 2019
\end{aligned}
$$




\section{Reviewers:}

Prof. nadzw., dr hab. Stanislaw Kunikowski, Rektor of Cuiavian University in Wloclawek (Republic of Poland);

Prof. dr hab. Joanna Marszalek-Kawa, Uniwersytet Mikołaja Kopernika w Toruniu / Nicolaus Copernicus University (Republic of Poland).

Man, society, politics: topical challenges of the modernity : collective monograph / N. M. Baklanova, O. V. Diachenko, L. M. Dunayeva, N. P. Hedikova, etc. - Lviv-Toruń : Liha-Pres, 2019. - 164 p.

ISBN 978-966-397-183-4

\footnotetext{
Liha-Pres is an international publishing house which belongs to the category „C” according to the classification of Research School for

\section{SENSE} Socio-Economic and Natural Sciences of the Environment (SENSE) [isn: 3943, 1705, 1704, 1703, 1702, 1701; prefixMetCode: 978966397]. Official website - www.sense.nl.
} 


\section{CONTENTS}

DEMOCRATIC MODERNIZATION

AND POLITICAL CULTURE

Baklanova N. M.

POLITICAL LANGUAGE TRANSFORMATION

IN DIFFERENT TYPES OF POLITICAL REGIME

Diachenko O. V. .15

COMMUNICATIVE MECHANISMS

IN THE SYSTEM OF POLITICAL RESPONSIBILITY

OF MODERN SOCIETY

Dunayeva L. M.

ENSURING NATIONAL SECURITY

OF UKRAINE UNDER THE CHANGE

OF INTERNATIONAL SECURITY ENVIRONMENT

Hedikova N. P

POST-COMMUNIST TRANSFORMATION AFTER 2004:

CASES OF POLAND AND HUNGARY

Koval I., Brusylovska O.

NECESSITY AND LIMITS OF STATE INTERVENTION

TO THE ECONOMY OF MODERN COUNTRIES

Muzychenko G. V.

.72

STATIST IDENTIFICATION

OF CITIZENS AS A STABILIZATION FACTOR

FOR UKRAINIAN SOCIETY

Pashyna N. P.

METHODOLOGICAL FOUNDATIONS

FOR MODELING CONTEMPORARY

POLITICAL ACTIVISM IN THE DIGITAL AGE

Polovyi M. A. 


\section{MULTIVARIATE MEASUREMENT CONCEPT}

"INFORMATION WAR"

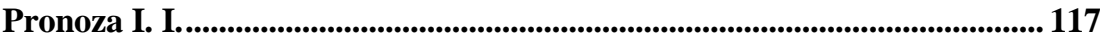

\section{THE IDEOLOGICAL PARADIGM OF PARLIAMENTARY}

PARTIES IN MODERN UKRAINE

Shchedrova H. P.

DIGITALIZATION IN THE FIGHT AGAINST

CORRUPTION IN UKRAINE

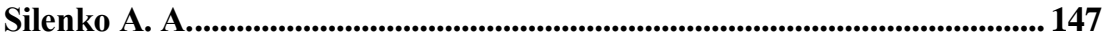




\section{DEMOCRATIC MODERNIZATION AND POLITICAL CULTURE}

\section{Baklanova N. M.}

\section{INTRODUCTION}

The problem of determining the role of the state in social life and the value orientations of the demos as a participant of political transformations are attracting increasing interest of political scientists. Despite different points of view regarding the essence of the state prevailing in various historical periods, the recognition of the role of the main political institution has remained unchanged. Ukrainian society like other states of Central and Eastern Europe, is at the epicenter of a global transformational dynamics. The democratic transformations in these countries marked the beginning of a new stage in the processes of democratization, the third one in the world political history (according to S. Huntington).

In states, the process of democratization is specific, but political science, based on comparative analysis, has elucidated a number of foreign policy factors on which its stability depends.

One of these factors that can directly contribute to or impede democratic political development is political culture. Using the specific historical method, the essence of understanding political culture as organically connected stereotypes of political consciousness and behavior in the society, as well as models of the functioning of political institutions and political regime as an important characteristic of the political system, were revealed. It was proved that there is some difference in the political culture of social subjects, which are driving forces at different stages of social development: at the stage of transition to democracy, it is the level of political culture of elites which is crucial and on which the form and effectiveness of political institutions' functioning depends directly; at the stage of establishing democracy, when new political institutions and procedures are introduced into the practice of everyday life, the level and significance of the political culture of masses increases.

Democratic political culture is a culture of civil society where the pluralism of interests of a wide variety of social and political forces dominates. The formation of a democratic political culture of masses is always the result of the effective functioning of democratic political institutions, and this takes time.

It is only a developed civil society where culture that corresponds to a democratic regime can be formed. Pluralism of political ideas implies the right of citizens to unite in political parties, public organizations, means their free 
and equal activity within the framework of a multi-party political system, the opportunity to take part in the political life of the country, and, thus, influence the activities of government and administration using the existing legal mechanism. And this, in fact, is a transition from a party-state system to a multi-party system and separation of powers. The political culture of Ukraine is largely determined by the history of its development. For many years at the crossroads of Western and Eastern political cultures, the political culture of the Ukrainian people and their mentality have been formed as a combination of various cultural components with a predominance of Western components.

The level of the mass consciousness of the Ukrainian society is characterized by inconsistency, segmentation, ideological and political diversity.

Ideas, orientations, moods, stereotypes of thinking and behavior cultivated by the Soviet regime have still existed in the society. And disappointment in the realities of the state authorities of nowadays, the social standard of living give rise to passivity, inertia, irresponsibility, moral primitivism. Along with the destruction of traditional structures and mechanisms of social integration, ambivalence becomes the dominant type of social orientation. At the present stage, the Ukrainian society is in urgent need not only to develop, but also to introduce a clear concept of integrating ideology which will contribute to national consolidation, the development of civil society, and hence a democratic political culture. It is well-known that the mechanisms of the formation and development of civil society in modern Ukraine are the national mentality and national-political activity, thereby affecting the level of political culture.

\section{Theoretical concept of political culture}

Since Antiquity, almost all scholars have addressed this issue to some extent in their works. Focusing on various aspects of the essence of the state, the authors understood in a different way the role and influence of this political institution on the life of society, it was Aristotle who perceived the state as a large patriarchal family ${ }^{1}$; the state within the framework of a religious worldview was considered as an earthly institution of power established by $\mathrm{God}^{2}$; or the state was seen as the result of a "social contract" to ensure the rights and freedoms of citizens ${ }^{3}$. At the same time, despite different points of view regarding the essence of the state prevailing in various historical periods, the recognition of the state's role as the main political institution has remained unchanged. Today, the state has still played a leading

${ }^{1}$ Аристотель. Сочинения: В 4 т. Т. 4 / [пер. с древнегреч.; общ. ред. А. И. Доватура]. М.: Мысль, 1983. С. 376-644.

${ }^{2}$ Аквинский Ф. Сочинения / [пер. А. Апполонова]. М.: Ленанд, 2015. 242 с. 1990. $524 \mathrm{c}$.

${ }^{3}$ Гегель Г. Философия права: Пер. с нем. / [ред. и сост. Д. А. Керимов]. М.: Мысль, 
role in the society. According to the just statement of T. Lowy, the "state" has not disappeared and does not show any signs of extinction in the modern world, this institution has been preserved with many traditional functions inherent in it. In addition, according to T. Lowy, the lack of protection by the state endangers personal freedom ${ }^{4}$.

The first of the currently known scientific studies on the embodiment of individual orientations in the mass social trends that determine politics was made by Aristotle, who believed that the nature and method of government's management reflect the "virtues" inherent in the members of a given society. Herodotus and Thucydides, comparing the cultures of Greeks and Persians, as well as Athenians and Spartans, emphasized the specific features of the political systems of these peoples and associated them with the influence of the prevailing in these societies values.

In the XVIII century, the idea that governing forms reflect population's values was supported by Charles Louis Montesquieu, and almost a century later, by Alexis de Tocqueville, who investigated "the civil spirit of the American nation manifested in the activities of political institutions in the United States ${ }^{5}$.

Seymour Lipset was one of the first to address the political and cultural issues of democratization in the late 1950s. This American political sociologist emphasized the impossibility of isolating any key factor from the close interconnection of various aspects of economic development (industrialization, urbanization, wealth and education) ${ }^{6}$. He believed that genuine democratic modernization is manifested in the transformation of social conditions and the development of political culture. For example, "educating an employee provides the establishment of wide contacts with various social groups ... in connection with which employees are more susceptible to democratic values"7.

In the modern pioneering work, "Civil Culture: Political Attitudes and Democracy in Five Countries," Gabriel Almond and Sydney Verba concluded that the stability and vitality of the political regime depend on its perception by citizens as an "appropriate form of governing", as well as on the actual

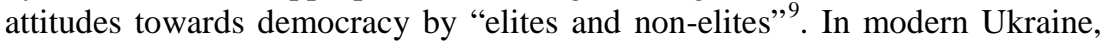
they stated that the slow formation of a democratic political culture at the institutional level is connected with the invariability of the political elite.

${ }^{4}$ Лоуи Т. Глобализация, государство, демократия: образ новой политической науки // Политические исследования. 1995. № 5. С. 108-119.

${ }^{5}$ Токвиль А. Демократия в Америке / Пер. с фр. - М.: Прогресс, 1992. 554 с.

${ }^{6}$ Lipset S.M. Political Man. The Social Bases of Politics. - NY.: Doubleday, 1960. 432 p.

${ }^{7}$ Lipset S.M. Some Social Requisites of Democracy: Economic Development and Political Legitimacy // American Political Science Review. 1959. № 53 (March). Pp. 69-195.

${ }^{8}$ Almond, Gabriel, Verba, Sidney. The Civic Culture: Political Attitudes and Democracy in Five Nations. - Princeton, 1963. 869 p.

${ }^{9}$ Barnes, S.H., Kaase, M. et al. Political Action: Mass Participation in Five Western Democracies. - Beverly Hills, CA: Sage,1979. 338 p. 
The unwillingness and inability of representatives of this elite to join the mechanism of interaction, the mood for conflicting forms of upholding their own political interests rather than reaching a political compromise, make the process of strengthening a democratic political regime and, accordingly, a democratic political culture, contradictory and inconsistent.

$\mathrm{R}$. Inglehart and $\mathrm{C}$. Weltzel demonstrate in detail the correlation between social and economic position (development) and commitment to the values of liberal democracy in the study, which, apparently, is the most authoritative and ambitious work of the last decade in the field of political culture. Scientists proceed from the provision that "the essential impact of modernization is not in the fact that democracy becomes acceptable to elites, but in the fact that the ability and desires of ordinary people to fight for democratic institutions increase" ${ }^{10}$.

The authors suggest that at the post-industrial stage of development, as a result of the growth of social and economic development, increased education, differentiation of the labor market and professions, the structure of the society is becoming more complex, where more and more creative, freethinking individuals are independent from the authorities: "Raising the level of education, expanding the need for obtaining information and the dissemination of knowledge by means of media helps people think more independently, reducing the restrictions on free choice" ${ }^{\prime 1}$. Naturally, with an increase in the total number of such individuals, the demand for civil rights and freedoms' realization increases. Thus, according to Welzel, "a person cannot be free without civil and political rights" 12 .

The emergence of an increasing number of informed and independentminded citizens, the formation of their associations, calls into question the legitimacy of authoritarian regimes that restrict citizens' political rights and freedoms. In such circumstances, the existence of authoritarianism becomes unacceptable for at least two reasons: firstly, "effective management becomes more expensive and restricting the institutional choices of elites"13, and secondly, "as a rule, authoritarian elites have enough power to suppress civil requirements, as long as they control the troops and are ready to use force. However, the resources that become a civil capital, and the determination with which citizens direct them to fight for freedom, can eliminate the power of

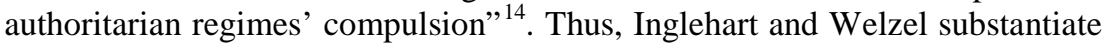

\footnotetext{
Pp. 126-140.

${ }^{10}$ Welzel, Christian and Inglehart, Ronald. Journal of Democracy, no. 19 (2008).

${ }^{11}$ Inglehart, Ronald and Welzel, Christian. Modernization, Cultural Change and Democracy: The Human Development Sequence. - Cambridge, 2005. 344 p.

${ }^{12}$ Welzel, Christisn. European Journal of Political Research, no. 45 (2006). Pp. 871-896.

${ }^{13}$ Ibid. Pp. 871-896.

${ }^{14}$ Inglehart, Ronald and Welzel, Christian. Modernization, Cultural Change and Democracy: The Human Development Sequence. - Cambridge, 2005. 344 p.
} 
the crucial role of ordinary citizens in the process of democratization and draw the mechanism of democratic attitudes' emergence at the micro level under the influence of modernization, which by means of implementing the request for political rights and freedom, are transformed into democratic institutions at the macro level.

So the key thesis underlying the study of political culture is the existence of a stable relationship between the value orientations of individuals and the nature of the political regime and stable functioning of institutions and the system as a whole.

With regard to the people power, this means that dominance of the democratic values of freedom, independent choice, etc. in the mass consciousness (that is, the opinion that the majority of the members of a given society share) determines the establishment, preservation and development of effective democratic institutions.

In the paradigm of the political culture study, effective democracy appears to be a mechanism for the institutionalization of civil rights and political freedoms which guarantees the possibility of independent choice in the private, public and state spheres. Obviously, a democratic order is not supported and maintained by any choice of citizens. The story contains quite a few illustrations of the crushing blows inflicted by the demos in the course of democratic procedures concerning people power. One of the most striking cases of the history of the XX century is the legal transfer of power to the Nazis in Germany and the ensuing rollback to fascist totalitarianism. Therefore, civil choice, which is motivated by the desire for freedom and independence, is crucial for democracy. So, the stability of the system and the regime depends on the mutual conformity of values and institutions. It follows from this that democracy successfully develops in societies whose members possess civil qualities and strive for freedom and independence. Even if authoritarian or totalitarian groups come to power in such societies, then, as the political history of the countries of Central and Eastern Europe shows, the pressure of social forces will not allow them to rule as long as they would like to. As Pamela Paxton maintains, the costs of tyrannical regimes to pacify the dissatisfied people increase under the influence of citizens seeking freedom and with the strengthening of antigovernment movements which decreases the effectiveness of autocratic systems, creates conflicts within the ruling class (between conservatives and reformers) and ultimately leads to a collapse of autocracies ${ }^{15}$.

It is important to emphasize here that we are talking about the processes taking place precisely in post-industrial countries. The transition to postindustrialism, which began around 1970, led to changes in the values of mass consciousness, which also influenced the nature of the democratic process and

\footnotetext{
${ }^{15}$ Paxton, Pamela. American Sociological Review, no. 67 (2002): 254-277.
} 
the perception of the very concept of democracy in developed countries. In this regard, a number of researchers have announced a "crisis" of liberal democracy in the West. The analysis of the theme of the "crisis" of liberal democracy reveals new patterns of realizing the values of democracy in modern postindustrial societies and compares them with those inherent in transitional societies. Therefore, it is worth considering this issue more closely.

Crozier was one of the first to write about the "crisis" in 1975. Putnam, together with Christine Goss, supported this statement in the early 2000s: "It's paradoxical, but during the grand triumph of liberal democracy, there are also some concerns about the effectiveness of the most important social institutions, including the institutions of representative power, in developed democracies" 16 .

Although Putnam and other equally authoritative authors substantiate political passivity observed in post-industrial societies as being a result of reduced "social capital", however, Inglehart and Welzel offer a different solution. These authors change their perspectives and it becomes clear that, in fact, there is not one, but two trends. "On the one hand, bureaucratic and elite-driven forms of people's participation in the political process, such as voting and party membership, are indeed declining. On the other hand, the volume of anti-elite forms of such participation, driven by expressive intrinsic motivation, has expanded dramatically" ${ }^{17}$.

Ulrich Beck explains the ongoing changes as a consequence of the diversification of relations between people conditioned by socio-economic development, abandoning the traditional ties and gaining the freedom to choose new social roles and creating social ties based not on coercion or necessity. According to him, in post-industrial democratic societies there is a transition from "forced kinship" to "sympathy according to one's choice"18.

Thus, social capital does not disappear, it updates its character and forms of manifestation, taking into account the changes in the social formation (from industrial to postindustrial). Today, members of postindustrial societies are less likely to join hierarchical-type political organizations and are more critical of state policy and bureaucracy, which is reflected, for example, in a decrease in voters' turnout for elections. On the contrary, people are increasingly participating in new forms of expressing interests: in single pickets, boycotts, signing petitions on the Internet, demonstrations organized through social networks, etc.

${ }^{16}$ Putnam, Robert and Goss, Kristine. Introduction. Democracies in Flux: The Evolution of Social Capital in Contemporary Society. - Oxford, 2002. 528 p.

${ }^{17}$ Инглхарт Р., Вельцель К. Модернизация, культурные изменения и демократия / Пер. с англ. - М.: Новое издательство, 2011. 464 с.

${ }^{18}$ Beck, Ulrich. Losing the Traditional: Individualization and «Precarious Freedoms». Individualization. London, 2002. Pp. 1-21. 
New forms of political participation were called "unorthodox", in contrast to the "traditional" ones (voting, voters' appeals to deputies, etc.). Back in the late 1970s, Barnes, Kaase, and their co-authors, exploring the protest potential, developed methods for measuring "traditional" and "unorthodox forms of participating in political activity", calling the latter "a stable characteristic of the general public in democratic countries"19.

The most significant contribution to understanding the process of the democratic values formation among citizens of a given society was made by the authors which can conditionally be divided into two main groups: institutionalists and communitarians.

Robert Jackman, Dunkwart Rastow, Ross Miller, Edward Muller, Mitchell Seligsen, Guillermo O'Donnell and Phillipp Schmitter believe that democratic values are formed in the population during the long-term and effective functioning of democratic institutions in the course of habituation or "institutional learning" ${ }^{20}$, thanks to the adoption of norms and the realization of the value of democracy. At the same time, economic development plays a supporting role, also contributing to the spread and strengthening of the values of democracy in the mass consciousness. An additional factor in strengthening democracy (in the context of existing democratic institutions) is economic growth. Such logic leads to the conclusion that it is impossible to create a culture that supports democracy under authoritarianism or totalitarianism. However, political history provides a lot of examples of the opposite. In modern times, the most striking illustration is the democratization of the USSR and the countries of the Soviet Union. In addition, the practice of the CIS and other countries shows that to establish democratic values in a society, it is not enough to adopt a democratic constitution and build institutions of representation and public control. Something else is needed.

Supporters of elitist conceptions write about the decisive role of the political elite in building and maintaining the stability of the institutional foundation of democracy. For example, Valerie Buns: "If political leaders are considered to be the founders of democracy ... then in the future, after the initial breakthrough, it is also them whom will determine whether it will be preserved or undermined" ${ }^{21}$. In this discussion, the following situation can be observed: the ruling class is in no way dependent on society, and citizens are just passive observers who are not able to influence politics. But here we are no longer talking about a democratic regime, because the interests of the demos are not taken into account in any way, which destroys the very essence of democracy.

${ }^{19}$ Barnes, S.H., Kaase, M. et al. Political Action: Mass Participation in Five Western Democracies. - Beverly Hills, CA: Sage,1979. 338 p.

${ }^{20}$ Rastow, Dankwart. Polis [Political studies], no. 5 (1996): Pp. 5-15.

${ }^{21}$ Bunce, Valerie. Comparative Political Studies, no. 33 (2000): Pp. 703-734. 
Therefore, we should not forget about the important role of social movements and the values shared by them, or, generally speaking, social forces that resist the pressure of the central government and want independence. In turn, these social forces were able to become influential actors due to an increase in their economic capital (as well as cognitive and social). Guillermo O'Donnell and Phillipp Schmitter argue that the main impetus for democratization is provided by the change-oriented and reform-minded elites who direct social forces and manage their collective actions to overcome the resistance of the conservative-minded part of the ruling class and renew the political system $^{22}$. The role of the social movement here is much more modest - only the execution of the political modernization program developed by a narrow group of elites. Further stability of democracy, according to Juan Linz and Alfred Stepan, depends on the degree of elite's agreement that democracy is the "only possible option" of political life ${ }^{23}$.

It is difficult to overestimate the role of the elite in democratization, especially in terms of building democratic institutions and supporting their working condition. In addition, it is difficult to imagine that even the most skillful actions of a small group of elite will help establish a stable democratic regime if there is no widespread support of the population.

Ferdinand Tönnis to analyze the collectivism (as the basis for theoretical models of democracy), distinguished between community and society. In his opinion, the community is firmly held together by uniform ties, providing a high level of cohesion, giving the group closeness and generating a collective identity.

Society, according to F. Tennis, is an open-ended group uniting individuals from different layers on the basis of similarity of interests and is a source of individualistic identification. Daphne Oiserman, Heather Kuhn, and Marcus Kemmelmeyer consider intra-group relationships and mutual obligations as the most essential characteristics of collectivism, which they call "interdependent" self-awareness.

In addition, the personal freedom of a team, collective member is limited not only by external obligations, it is also constrained by the internal suppression of individual needs that run counter to social ones, as well as by the need to constantly adapt to the interests of the group, because there is no other choice.

So, collectivism is not a specific integral feature of any culture. The explanation of collectivism as a way of protecting a group in the face of danger suggests that in any society in a critical situation, the collectivist values

${ }^{22}$ O’Donnell, Guillermo, Schmitter, Philipp. C. Tentative Conclusions about Uncertain Democracies. Transitions from Authoritarian Rule. Baltimore, 1986. Vol. 4. Pp. 1-78.

${ }^{23}$ Linz, Juan, Stepan, Alfred. Problems of Democratic Transition and Consolidation: Southern Europe, South America and Post-Communist Europe. - Baltimore, 1996. 504 p. 
of group discipline, a unified norm, powerful state power, with the help of which overall vitality is most effectively achieved, prevail in the mass consciousness.

\section{National and political activity as an important mechanism for developing a democratic political culture}

Ukrainian nation is now in a situation where both the process of civil society development and the process of transformation of national consciousness take place, which determines the specifics of moral and ethical values' formation. Although these two processes are equal in importance, the system of moral and ethical values of civil society originates from national foundations and traditions, yet the general foundations for the development of civil society are much broader than the national foundations for functioning and transformation of national borders and statuses. National traits in one way or another influence the processes that promote or impede the development of civil society.

The process of building a nation takes on the character of political certainty with the proclamation of Ukraine as a democratic state, thus, such a society is formally formed on an appropriate national basis. This process is characterized by the will of citizens and the level of freedom of choice in determining national and civil priorities when choosing a language of communication, the values of state symbols, and it is also necessary to take into account the specific features of social institutions' functioning.

Civil society in the world has become an objective condition for the existence of a nation in democratic states, and yet, this does not mean that the features of its formation and functioning are the same for all countries and world communities. All these communities are united by the fact that the foundations of the civil society development are formed by the global conditions for the functioning of social relations that correspond to a particular historical era.

The twentieth century is also the bearer of the corresponding traits that became the basis for the formation of the nation and the mechanisms of the civil society development. Thus, considering civil society as a social phenomenon that accumulates certain mechanisms leading to changes in the society, and to a greater extent to changes in consciousness, it is necessary to take into account the national characteristics of the social system development. It is also important to take into consideration the specifics of the historical features of the nation formation in order to determine the directions of the civil society development in any state, that is why we focus on the study of the mechanisms of formation and further civil society development based on the national mentality of the Ukrainian people. And the success of this process will depend on the level of political culture in the society. 
As the experience of Ukraine's development in recent decades has shown, it can be concluded that gradual and spontaneous changes in the consciousness and morals of citizens are an invariable condition for progressive transformations, and, of course, not without the state's influence through education and upbringing. Such influence should not be carried out as a party propaganda or ideology, but as an independent and important direction in public policy.

The formation of civil society is influenced by individual conditions that determine the national specifics of its development. Thus, civil society is a form of social activity organization which is formed on a certain basis including the joint territorial location of the national community, the language of communication, the specifics of economic development and political governance.

The mechanisms of formation and development of democratization (civil society) in modern Ukraine are the national mentality, national and political activity, which contribute to the development and raising of the level of democratic political culture.

In scientific studies on the process of the civil society development, various factors are distinguished: social responsibility, elections, independence of self-government, media responsibility, civil control, and others. However, the role of the national mentality of Ukrainian nation in this process has not been fully studied yet.

The national mentality enshrines social and national symbols that preserve and convey the history of the will of the Ukrainian people. It is very important to take into account the fact that people defended their own national interests in unfavorable conditions, and many of them were not realized. And this fact it is vital to take into account this fact because unrealized dreams of freedom and national images form an obstacle in the subconscious in the form of fear that subsequent attempts will also result in defeat or punishment. In addition, state dictatorship and monopoly control over the activities of various social institutions became a prerequisite for the cessation of their activities and absence of any initiative on the part of an individual.

Thus, objective conditions have formed in the national mentality of the Ukrainian nation the idea that public organizations can maintain independence and the right to autonomy from the invasion of state institutions only when there is the state's permission for that, or if they are economically protected, which allows them to exercise legal regulation of relationships with state institutions limiting their intervention.

A nation is also formed on the basis of the joint interaction of different ethnic groups that historically live on a particular territory. It is the basis of agreement of all representatives of ethnic groups, the joint experience of managing and a single will to unite around a priority ethnic group where a 
nation can be formed, and the role of the state in this case is to provide legal support for such coexistence. "No one will build a state for us unless we build it ourselves, and none of us will make a nation if we do not want to be a nation ourselves" 24 .

The national mentality is formed based on the joint experience of coexistence and cultural traditions in different areas of public life: economic, political and cultural.

National and political activity as a mechanism of social maturity of a society is structured in a certain way, it is realized through behavior, motives, desires, interests of different social groups which are united in a nation. Thus, political culture acts as a consolidating factor in the formation of a democratic state.

Thus, there is a close relationship between political culture, economic development and stable democracy. "Values and social relationships are interconnected and mutually developing." The effective work of institutions is associated with "civil virtue": "a republic grows a virtuous individual, and a virtuous individual creates a republic. Views and practice constitute a mutually developing balance. The effectiveness of institutions and their attention to the needs of the population depends on "republican virtues" and practice. Social environment and history deeply affect the performance of institutions. If the regional foundation is favorable, the regions have support from regional traditions, but when this foundation is scarce, new institutions are ineffective $" 25$.

Thus, the formation of the political culture of the new - democratic type - will depend on many factors and, above all, on the pace of development of national political elite's and each individual's self-awareness, on their social protection and real, not declared, rights and freedoms, as it should be in any civil society.

\section{CONCLUSIONS}

Democratic transformations in European states, including Ukraine, marked the beginning of a new stage in the processes of democratization, the third one in the world political history. One of the factors that can directly contribute to or impede democratic political development is political culture. In the paradigm of the study of political culture, effective democracy appears to be a mechanism for the institutionalization of civil rights and political freedoms, and guarantees the possibility of independent choice in the private, public and state spheres. The stability of the system and the regime depends

${ }^{24}$ Липинський В. Листи до братів-хліборобів. Про ідею і організацію українського монархізму. - Відень, 1926. - С. 15.

${ }^{25}$ Патнам Р. Д. Творення демократії: Традиції громадянської активності в сучасній Італії / Р. Д. Патнам, Р. Леонарді, Р. Й. Нанетті ; пер. $з$ англ. В. Ющенко. - К. : Вид-во Соломії Павличко «Основи», 2001. - 302 с. 
also on the mutual conformity of values and state institutions. The mechanisms of formation and development of democratization (civil society) in modern Ukraine are the national mentality, national and political activity which contribute to the development, raising of the level of democratic political culture.

National and political activity as a mechanism of society's social maturity is realized through behavior, motives, desires, interests of different social groups which are united in a nation. The formation of political culture of a democratic type depends on many factors and, above all, on the pace of development of the political elite's and each individual's national selfawareness, their social security and the realization of rights and freedoms. State policy in this direction should be focused, stable, based on the principles of high morality, justice and law.

\section{SUMMARY}

Ukrainian society, like other post-communist states of Central and Eastern Europe, is at the epicenter of global transformational dynamics. The democratic transformations in these countries marked the beginning of a new stage in the processes of democratization, the third one in the world political history. One of the factors that can directly contribute to or impede democratic political development is political culture.

Despite the existence of different points of view regarding the essence of the state prevailing in various historical periods, the recognition of the role of the main political institution has remained unchanged. In the scientific studies of various authors, we see the embodiment of individual orientations in mass social trends that determine politics, specific features of political systems, linking them with the influence of the values prevailing in these societies. Thus, the key thesis underlying the study of political culture is the presence of a stable relationship between individuals' value orientations and the nature of the political regime, the stable functioning of institutions and the system as a whole. With regard to democracy, this means that dominance of the democratic values of freedom, independent choice, etc. in the mass consciousness (which is shared by the majority of the members of a given society) determines the establishment, preservation and development of effective democratic institutions.

The Ukrainian nation is now in a situation where both the process of civil society development and the process of transformation of national consciousness take place, which determines the specifics of moral and ethical values' formation. The system of moral and ethical values of civil society, first of all, originates from national foundations and traditions. The mechanisms of forming and developing civil society in modern Ukraine are the national mentality, national and political activity which contribute to the development, raising of the level of democratic political culture. 
In scientific studies on the process of the civil society development, various factors are distinguished: social responsibility, elections, independence of self-government, media responsibility, civil control, and others. However, the role of the national mentality of Ukrainian nation in this process has not been fully studied yet.

The national mentality enshrines social and national symbols that preserve and convey the history of the will of the Ukrainian people. National mentality is formed based on the joint experience of coexistence and cultural traditions in different areas of public life: economic, political and cultural. National and political activity as a mechanism of society's social maturity is structured in a certain way, it is realized through behavior, motives, desires, interests of different social groups which are united in a nation. An indicator of the social maturity in modern Ukraine is its own model of democratic political culture. Thus, political culture acts as a consolidating factor in the formation of a democratic state, civil society and a factor of political progress. Thus, the state policy in this direction should be focused, stable, based on the principles of high morality, justice and law.

\section{REFERENCES}

1. Аристотель. Сочинения: В 4 т. Т. 4 / [пер. с древнегреч.; общ. ред. А. И. Доватура]. М.: Мысль, 1983. С. 376-644.

2. Аквинский Ф. Сочинения / [пер. А. Апполонова]. М.: Ленанд, 2015. $242 \mathrm{c}$.

3. Гегель Г. Философия права: Пер. с нем. / [ред. и сост. Д. А. Керимов]. М.: Мысль, 1990. 524 с.

4. Лоуи Т. Глобализация, государство, демократия: образ новой политической науки // Политические исследования. 1995. № 5. С. 108-119.

5. Токвиль А. Демократия в Америке / пер.с фр. - М.: Прогресс, 1992. $-554 \mathrm{c}$.

6. Lipset S.M. Political Man. The Social Bases of Politics. - NY.: Doubleday, 1960. 432 p.

7. Lipset S.M. Some Social Requisites of Democracy: Economic Development and Political Legitimacy // American Political Science Review. 1959. № 53 (March). Pp. 69-195.

8. Almond, Gabriel, Verba, Sidney. The Civic Culture: Political Attitudes and Democracy in Five Nations. - Princeton, 1963. 869p.

9. Barnes, S.H., Kaase, M. et al. Political Action: Mass Participation in Five Western Democracies. - Beverly Hills, CA: Sage, 1979. 338 p.

10. Welzel, Christian and Inglehart, Ronald. Journal of Democracy, no. 19 (2008). Pp. 126-140.

11. Inglehart, Ronald and Welzel, Christian. Modernization, Cultural Change and Democracy: The Human Development Sequence. - Cambridge, 2005. 344 p. 
12. Welzel, Christisn. European Journal of Political Research, no. 45 (2006). Pp. 871-896.

13. Welzel, Christisn. European Journal of Political Research, no. 45 (2006): 871-896.

14. Inglehart, Ronald and Welzel, Christian. Modernization, Cultural Change and Democracy: The Human Development Sequence. - Cambridge, 2005. 344 p.

15. Paxton, Pamela. American Sociological Review, no. 67 (2002): 254-277.

16. Putnam, Robert and Goss, Kristine. Introduction. Democracies in Flux: The Evolution of Social Capital in Contemporary Society. - Oxford, 2002. 528 p.

17. Инглхарт Р., Вельцель К. Модернизация, культурные изменения и демократия / Пер. с англ. - М.: Новое издательство, 2011. 464 с.

18. Beck, Ulrich. Losing the Traditional: Individualization and «Precarious Freedoms». Individualization. London, 2002. Pp. 1-21.

19. Barnes, S.H., Kaase, M. et al. Political Action: Mass Participation in Five Western Democracies. - Beverly Hills, CA: Sage,1979. 338 p.

20. Rastow, Dankwart. Polis [Political studies], no. 5 (1996): Pp. 5-15.

21. Bunce, Valerie. Comparative Political Studies, no. 33 (2000): Pp. 703-734.

22. O’Donnell, Guillermo, Schmitter, Philipp. C. Tentative Conclusions about Uncertain Democracies. Transitions from Authoritarian Rule. Baltimore, 1986. Vol. 4. Pp. 1-78.

23. Linz, Juan, Stepan, Alfred. Problems of Democratic Transition and Consolidation: Southern Europe, South America and Post-Communist Europe. - Baltimore, 1996. 504 p.

24. Липинський В. Листи до братів-хліборобів. Про ідею i організацію українського монархізму. - Відень, 1926. - С.15.

25. Патнам Р. Д. Творення демократії: Традиції громадянської активності в сучасній Італії / Р. Д. Патнам, Р. Леонарді, Р. Й. Нанетті ; пер. 3 англ. В. Ющенко. - К. : Вид-во Соломії Павличко «Основи», 2001. $-302 \mathrm{c}$.

\section{Information about the author:} Baklanova N. M.,

Candidate of Political Sciences, Associate Professor at the Department of World History and Methodology of Science, South Ukrainian National Pedagogical University named after K. D. Ushynsky 26, Starofrankivska str., Odessa, 65020, Ukraine 


\section{POLITICAL LANGUAGE TRANSFORMATION IN DIFFERENT TYPES OF POLITICAL REGIME}

\section{Diachenko O. V.}

\section{INTRODUCTION}

In the modern political process and political activity, such political situations appear when manipulative techniques are used by the subjects of political life. Communication technologies in the modern practice of political management are intensively used to form perception models of sociopolitical reality by the society, as well as the mass behavior models designed to maintain the stability of the existing political regimes and achieve political management subject purposes. Appropriate techniques and means of linguistic-manipulative influence differ in their composition and forms of manifestation in different political processes. At different levels of the political process, a various set of linguistic-manipulative influence is used to achieve goals and introduce their political will into the public consciousness. There are many different factors that affect this. An important factor is one or another type of political regime according to which the strategy and influence tactics of this type are defined.

The effectiveness of the state political system is largely determined by the successful formation of relevant public perceptions of the national political system, national leaders or the political elite, state government institutions, etc. In addition, the manifestations of the population's behavioral reactions to various political events, both within the country and abroad, largely affect the stability of a particular type of political regime.

Political language possesses specific properties when applied within the framework of communication. According to N. Fairclough "the communication purpose in this case is sense, development or change of imperious relations, and the factors - actors of external character (political leaders, influence groups, etc.). Under these conditions, the speech effect is quite expressed. This effect is usually the result of a certain ideology. The latter is not only a modern alternative application of material impact or violence" ${ }^{1}$. Regarding the author's position of this paper, it is different. On the contrary, "ideology can support the use of violence in any form: from intellectual, spiritual or moral to physical” 2 .

1 Щербинин А. (1999) «С картинки в твоем букваре» или Аз, Веди, Глагол, Мыслете и Живете тоталитарной индоктринации. Полис, 1, 116-136.

${ }^{2}$ Ibid. 
Scientists M. Hrachov, H. Pocheptsov, P. Serio and others consider the political language as a relevant subsystem of the common national language, which performs the communicative function of the political direction. Namely, it carries out propaganda or introduces any ideas, exercises an emotional influence on the society and provokes a person to commit any political actions, etc. $^{3,4,5}$. In particular, P. Serio draws attention to the functions of the political language and notes that the main thing is "verbal support of the struggle for power" ${ }^{\circ}$.

In our view "political language is a reflection of political reality and, at the same time, a means of its formation, since it sometimes decides the fate of laws, politicians and parties. The political phenomenon is transformed into something sensible and accessible for discussion, expressed in words, so the basic concepts of political language, political formulas and clichés largely determine the way of perceiving political reality. The political process develops together with the language, relies on the language, and uses the language itself" ${ }^{\text {? }}$.

\section{Features of the political language of a totalitarian model of political communication}

Analyzing the interrelationship between the political process and political language, $\mathrm{H}$. Pocheptsov notes "solid scientific literature describing the relationship between political realities and their reflection in the language makes it possible to speak of the existing correlation of these two phenomena: the political process and the political language”. According to the scientist "the practice shows that the dissemination control of information of political nature is an important element in determining the type of political regime: under authoritarianism and totalitarianism, information processes are under strict control, while a democratic regime implies that political information is widely and freely distributed between various members of the society" ${ }^{8}$.

In the case of a democratic communication model, it should be based on political or social dialogue between those who govern and the governed. It is this element of communication interaction that enables the exchange of accurate and complete information that is uniform and reliable in relation to real political events and situations. It is this approach that corresponds to the generally accepted cultural and civilizational values of modern society and reflects the rights and freedoms of fundamental nature in the personality

\footnotetext{
${ }^{3}$ Грачев М. (1996) Актуальные проблемы политической науки. М.,188.

${ }^{4}$ Почепцов О. (1987) Коммуникативные аспекты семантики. Киев, 129.

${ }_{5}^{5}$ Серио П. (1999) Как читают тексты во Франции. Квадратура смысла. М., 12-53.

${ }^{6}$ Ibid.

${ }^{7}$ Дяченко О. (2016) Особливості мовно-маніпулятивного впливу за різних типів політичного режиму. Актуальні проблеми політики. Одеса, 58, 29-40.

${ }^{8}$ Серио П. (1999) Как читают тексты во Франции. Квадратура смысла. М., 12-53.
} 
development. The mutual exchange of information, which is important in political life, is based on these principles. With regard to the Soviet era, there were clear traditional rules of political communication - "all the communicants knew who, what, when, and in what form they should talk" .

In continuing this problem, it is worth paying attention to the so-called public ritual communication, which was a characteristic feature of the Soviet era. O. Baranov's statement that "the main task of public ritual communication is to fix its adherence to the rules for confirming its social role" ${ }^{\# 10}$ is correct in this regard. And here the question arises: is there such a form of communication in the modern political process”? According to Ye. Zemska's belief "modern political communication is sometimes not less ritual than in Soviet times, but now the ritual rules and roles of communicants have changed. A modern ritual is the fulfillment of the public defender roles, a human rights advocate, a patriot, a centrist, etc. by the politician”11. M. Hrachov, the researcher who has repeatedly cited, has the same viewpoint pointing out that "it is also peculiar to the democratic model of communication, especially for political discourse, where the primacy of values appears to be taken over facts, the predominance of influence and evaluation over information, emotional over rational" ${ }^{12}$. Such conditions are favorable ground for the application of various language manipulations.

For the modern stage, political language is characterized by "semantic uncertainty (politicians often prefer to express their opinions in the most general way possible, using words of extended or vague semantics); phantom (many signs of a political language do not have a real subject); irrationality (attention to the subconscious); esotericism (the real meaning of many political expressions are understood only by the elected); theatricality"13. At first glance, the above features "contradict the main purpose of communication of conveying certain information to the addressee"14. However, according to the article's author: "almost each of these properties is capable of serving the manipulative strategies of the speaker: uncertainty and phantomity allow veiling the true meaning of the expression, to get away from a specific answer; irrationality and theatricality increase the impact on the listener; esotericism focuses the audience, divides everyone into the initiates and the uninitiated" ${ }^{15}$. But it should be noted that

9 Дяченко О. (2016) Особливості мовно-маніпулятивного впливу за різних типів політичного режиму. Актуальні проблеми політики. Одеса, 58, 29-40.

${ }_{10}^{10}$ Баранов А. (2001) Введение в прикладную лингвистику. М., 360.

11 Земская Е. (1996) Клише новояза и цитация в языке постсоветского общества. Вопросы языкознания, 3, 23-31.

${ }^{12}$ Грачев М. (1996) Актуальные проблемы политической науки. М.,188.

13 Дяченко О. (2016) Особливості мовно-маніпулятивного впливу за різних типів політичного режиму. Актуальні проблеми політики. Одеса, 58, 29-40.

${ }^{14}$ Ibid, 29-40.

${ }^{15}$ Ibid. 
in the Soviet era, the mass media were not free and therefore, political speech obtained propaganda and agitation nature.

In this way, the totalitarian model of political communication is characterized by the relevant take over the public consciousness and instills a comprehensive political ideology, the task of which is the establishment of "absolute truth" and the impossibility of any other options and interpretations of socially significant events. It should be noted that it leads "to an attempt to destroy the freedom of personality and society, political, cultural, religious and linguistic freedom. The main features of totalitarian ideology include: teleological (purposeful) orientation in views on social development, which forms an attractive happy image of the future, eliminates everyday difficulties from the public consciousness; paternalistic character (protection, paternal attitude of the leaders to the people, gives a favorable ground for the manipulation of mass social consciousness" 16 .

With regard to the characteristics of the political language of the totalitarian model of political communication, it is possible to distinguish "a high degree of cliché, euphemism, violation of the fundamental communication postulates used for the purpose of linguistic manipulation, ritualized use of language, desemantization of not only of individual words but also of large discourse segments" ${ }^{17}$. This type of communication is also characterized by the polarization of "friend-or-foe" political rhetoric, which has an influence on the thinking formation at the social level, which confirms the thesis about the interrelation of political language and world view. G. Orwell made a reference to it believing that "control over language, through the use of words in a society, will determine the limits of the permissible mental process" ${ }^{18}$.

It should be noted that the educational, pedagogical component, which directly affects the corresponding model formation of political communication, in particular, in the framework of totalitarianism. Here, the point is about the distinction between education and propaganda, since language is a means and tool of education. C. Becker drawn attention to this believing that "the preaching of what we believe in is education and preaching of what we do not believe in is propaganda" ${ }^{19}$. Political discourse in a totalitarian communication model involves two essential language characteristics: it, in this case, acts as a means of propaganda and, at the same time, an education tool. This makes it possible to work in promoting education component

${ }^{16}$ Дяченко О. (2016) Особливості мовно-маніпулятивного впливу за різних типів політичного режиму. Актуальні проблеми політики. Одеса, 58, 29-40.

17 Земская Е. (1996) Клише новояза и цитация в языке постсоветского общества. Вопросы языкознания, 3, 23-31.

${ }^{18}$ Оруэлл Д. (2013) Роман. Скотный Двор. Сказка-аллегория. М., 412.

${ }^{19}$ Беккер К. (2004) Словарь технической реальности: Культурная интеллигенция и социальный контроль. М., 65. 
propaganda. A. Shcherbinin notes in this regard that "primer for adults (literacy elimination) and primer for children (literacy education) form the students' class position. Such primer can be rightly called the shortest course of the AUCP (All-Union Communist Party (of the Bolsheviks)) ${ }^{20}$.

The main problem in this model is that, in such a society, the people understand that the dominant ideology does not reflect reality, but no one is able to change this situation. The cultural-political manipulation can create such a situation using the verbal component. In such models, there can be no full-fledged official opposition force that could create appropriate protest political discourse. In order not to become the cause of conflicts, the authority changes the political language perspective and, for example, begins to use a large number of euphemisms.

The analysis of current political processes in the world makes it possible to say that a totalitarian political regime is not an impossible thing in the future, and it poses a real threat to the fundamental foundations of the development of a civilized society. Increasingly, we see totalitarian political rhetoric and manifestations of certain features of totalitarian political language in the media.

According to the author "a political language in a totalitarian regime is characterized by: monologue of communication (unilateral influence on the addressee - society); lack of alternative sources of linguistic influence and feedback; clichéd and ritualized communicative behavior; absolutization of the political language written form (spontaneous speech disappears, oral public speeches must first be spelt out and verified); anonymity of individual discourses, the pattern of expression of ideas and opinions" ${ }^{21}$.

\section{Features of the democratic model of political communication language}

It is considered that "unlike the totalitarian regime, a dialogue between those who govern and the governed, based on a democratic and tolerant model of political communication, which provides for an equal exchange of accurate, complete and verified information about political phenomena and processes that are combined with basic civilized and cultural values of a given society, fundamental rights and freedoms of the individual”. In addition, it should be noted that "in a democratic society, the essence of political communication changes: every citizen has the right to participate in government, as well as the right to choose positions, to publicly evaluate the actions of the authorities"22.

${ }^{20}$ Щербинин А. (1999) «С картинки в твоем букваре» или Аз, Веди, Глагол, Мыслете и Живете тоталитарной индоктринации. Полис, 1, 116-136.

${ }^{21}$ Дяченко О. (2016) Особливості мовно-маніпулятивного впливу за різних типів політичного режиму. Актуальні проблеми політики. Одеса, 58, 29-40.

${ }^{22}$ Ibid. 
A variety of ideas, views and opinions inform the society and allow people to understand something in the analysis of political situations. Such freedom, which is possible for a person in a democratic society, in a democratic political regime, the society is provided with the opportunity to develop, and the ability to freely express one's thoughts and assessments regarding the current political process. This, in turn, shapes different views, political ideas and trends, and new socio-political movements and parties emerge, is a manifestation of political pluralism. All this diversity is a prerequisite for a widely recognized political discourse to be divided into state, party and group. The subjects of state political discourse are the representatives of the state authority at all government levels, and they represent the "official political communication".

The next type of discourse - party, includes members of political parties regarding their party activities and the language of party documents. The purpose of a particular discourse is the formation of public opinion, its mobilization and direction in support of the political movement.

It should be emphasized that "the emergence of a multi-segmental political discourse is possible due to democratic transformations in the society. At the modern stage, the political and media segment is changing most dynamically. The mass media is an influential subject of politics that shapes public opinion, public consciousness, organizes and exerts influence on public behavior" ${ }^{23}$. And here it should be emphasized that the media, which do not have such official powers, which are in other branches of government, but the ability to influence society, public opinion, political events - is even greater. And this is possible in a democratic model of political communication.

Now society has opportunities to provide up-to-date information that directly affects mass, group and individual consciousness and political behavior. The level of activity, independence and self-dependence of the media is an indicator of the type of political regime, the direction of the authorities' activity, and therefore political communication in the media has its own functions. They act as agents for the formation of political culture, identify political opinions and benchmarks, provide platforms for real societal participation in the political process, perform integration activities, and encourage society to acquire the new priority of political values and ideas and so on. There is an interesting fact that the media in the democratic regime also perform a controlling function which "integrates interests around some doctrines and formulates the party credos; it is through the press that parties engage in dialogue with each other without meeting; agree without contacting. When, however, it happens that a large number of print editions begin to act in one direction, their influence for a long time

${ }^{23}$ Дяченко О. (2016) Особливості мовно-маніпулятивного впливу за різних типів політичного режиму. Актуальні проблеми політики. Одеса, 58, 29-40. 
becomes prevailing, and public opinion, which is processed all the time on the one hand, as a result, is influenced" ${ }^{24}$.

According to $\mathrm{H}$. Khazarehova, today "the use of political language during election campaigns applying the techniques and methods of advertising business as a communicative influence is of great importance. The most striking example of the merging of political and advertising technologies in shaping political language is the election postcard" 25 . As the scientist notes "losing the informative nature in exchange for influence, the postcard, instead of information about the candidate, gives a simplified idea of the person to be selected. The political postcard demonstrates the presence of all trade advertising components: trademark, a slogan, difficult situation, product representation, a facilitated situation and motivational component" ${ }^{26}$.

The name and image of the politician is a trademark, the slogan is the appropriate political motto. "The difficult situation looks like the existing unsatisfactory state of affairs, the facilitated situation is a promise that the situation will improve for the better with this candidate's accession to power, and the motivational component is an explanation of why this will happen ${ }^{27}$.

According to the political discourse principles, the political name includes the names of the most popular politicians, parties or movements, for example, the names of the political party "Freedom", "People's Front", "Opposition Bloc" -is already a suitable political brand. The democratic model of political communication has a wide variety of language tools. This gives broad opportunities for the influence text area. This freedom of choice of tools ensures that voters have political texts accessible and understandable. For example, during the 2010 election campaign, politicians used such political slogans that were simple enough and understandable for the voters of the time; "We will raise the economy - we will raise the country", "Professionals should lead the country" (S. Tihipko), "They are destroying, she works", "she will win, she is Ukraine" (Yu. Tymoshenko), "Ukraine for the people", "I will hear everyone" and others.

The educational and pedagogical direction of the democratic model of political communication must also be developed. Attention should be paid to the methodological part, the creation of various new textbooks, various author's programs, special courses, which provides freedom of choice.

In other word, such a democratic model of political communication is characterized by the following features: "communication dialogue"; pluralization of people's communicative behavior (language strategies vary depending on the position of the communicants, the communication type, the

\footnotetext{
${ }^{24}$ Токвиль А. де (1992) Демократия в Америке. М., 560.

${ }^{25}$ Фуко М. (1997) История безумия в классическую епоху. СПб., 576.

${ }^{26}$ Ibid.

${ }^{27}$ Ibid.
} 
communication participants' personal characteristics); development of public speeches (especially its oral varieties: spontaneous speeches, public real-time communication - interviews, conversations, talk shows, public discussions, political debates); communication personification (uniqueness of expression and expression of similar ideas and thoughts by different people)"28. To this, one could also add: the composition expansion of the political communication recipients significantly increases the role of interactive communication and so on. This applies to the self-structuralization of relevant discourse practices that use the media.

When it comes to post-communist countries, one must take into account the corresponding hermetic privacy that reflects the specific "opacity" zones that have emerged in society. In such societies, the language used in newspapers, clichés and stereotypes that were present there became popular in the transitional phases and most strongly expressed the articulation of an unstructured underdeveloped society with non-standard components. This is covert aggression, a large number of metaphors in political rhetoric. The presence of aggression characterizes this model from the perspectives of intimidation, violence, coercion peculiar to the totalitarian model. The metaphors show lack of responsibility and "non-discursiveness" of public dialogue. It is the presence of a large number of metaphors that reflects the subconscious in the extra linguistic field. The result is the emergence of affects that substitute for an adequate discursive practice. There is a situation when the media create some kind of infrastructure of the public sphere and therefore, discursive practices disappear. As a result, instead of shaping people's foresight through reasoning and public opinion, there is a multiplication of fuzzy paleo-symbolic language with different stereotypes and specific party (political) jargon. Although it is precisely in this that the manipulative nature of the public word, which is present in the totalitarian model of political communication, is manifested. In Soviet times, these types of rationality were formed, which, together with the value priorities that had been formed earlier under the old regime, changed political discourse to a state of "clinical" monologism. Important socio-economic developments and political decisions have become propaganda tools.

Later, in the post-communist period, the phenomenon of democratic governance simulation formed. It reflected in the fact that a person who does not possess any means of exercising power is responsible for the efficiency of the state. The practice of "double morality", which is characteristic of the social consciousness of the Soviet model and the "internal censorship" system, which is one of the elements of such consciousness, is spreading.

${ }^{28}$ Дяченко О. (2016) Особливості мовно-маніпулятивного впливу за різних типів політичного режиму. Актуальні проблеми політики. Одеса, 58, 29-40. 
Therefore, it is quite difficult to talk about political discourse in the socalled "transition period". The social dialogue in question in post-communist countries has been largely distorted by totalitarian values and traditions of totalitarian political language. This significantly complicates the process of transition to democratic political discourse, which is one of the sources of legitimacy of the institutions of a developed civil society.

In post-communist countries, a form of linguistic behavior, which replaces public dialogue with relevant semantic articulations, is widespread. They act as some aggregates of violence, coercion, some specific conventions. The function of discourse as a vehicle, which combines the rational traits of the individual and the collective in society, does not work here. In such circumstances, the former needs, values and dreams are no longer amenable to understanding and defining in political discursive practice, and therefore, their meaningful content is in the field of non-political reality.

The approach initiated by M. Foucault in his work "The History of Madness in the Classical Era" may be quite productive for analyzing the practice of political discourse in post-communist countries. The main concept in the work was the term "deviation", and the term "language" acts as an element of madness. Foucault states that "if we introduce democratic discourse as a dialogical ethic, then rejection will always indicate a violation of such ethics rules, a potential opportunity to fall into an affective state, which can be expressed on a linguistic level by irony, silence, stereotyping, metaphorical chatter, hidden or open threat" ${ }^{29}$. As noted above, public dialogue in post-communist countries is being replaced by any form of tyranny's affects. Accordingly, it is very difficult to speak of a democratic model of political communication, because the formation of political discourse in such circumstances will be an unstable and moving process. Following the events of 1917, when sociocide was allowed, the final destruction of civil society institutions occurred and the basis of "dialogic" linguistic ethics, which was replaced by loyalty ritual, disappeared.

Political discourse restoration was made possible by the "education restructuring" and not by the development of civil society institutions. This was a consequence of the repressive system of human entry into social life. This process was characterized by manipulative traits and ensured that a person was constantly in the propaganda field, which was filled with compulsive impulse. When this field began to crack, many contradictions arose within the framework of public political dialogue. Today, there is mass involvement in the introduction of political rhetoric of people possessing different experience, occupation, education and, above all, they lack economic freedom. And this, in turn, makes them incapable of understanding special

\footnotetext{
${ }^{29}$ Фуко М. (1997) История безумия в классическую епоху. СПб., 576.
} 
terminology in the fields of economics, politics, philosophy, etc. That is, such a speech activity spurt is the result of the ideology of equality and was characteristic of societies with the class illusion, and then substantial proletariat advantages.

Some paradoxical situation in which the lack of the institutional traditions of civil society does not form democratic political discourse and hampers such society democratic institutions creation arises.

The key element in the politics of the post-communist period is the political language factor, discourse, political rhetoric. This is the rhetoric of a good future that has to be legitimized in political discourse and real social forms. That is, through political language, a reciprocal feeling is formed that the whole society influences progressive processes (market, democracy, freedom, reforms). However, society did not understand that this feeling does not guarantee this development. That is, from the experience of other countries that have already gone this route, it can be stated that progressive development depends on how much it is possible to master the current situation at the level of political discourse, because practically, everyone involved in global changes in society and its basic principles of life, should perform transition from the tacit support of the authorities to active political discourse. And this is one of the main elements from which politics is created.

Moreover, the priorities change in the political values perspective happens not only with political scientists, but this change must take place in the minds of the whole society. It is a broad involvement of the public in active political discourse, which ensures, for example, a high level of activity in elections or in the activities of power structures. Today, already quite broad masses, both at the conscious and the unconscious levels, have acquired the "Zoon politcon" qualities. These are the qualities that make it possible to understand the importance of political events and how these events affect everyday social life. And most importantly, these qualities make it possible to understand the relationship between the perspectives of one's life and the state development directions. In this process of entering into the political process communicative competence is formed and the person already at a conscious level makes any political choice and carry out, accordingly, socially important actions. That is, in the post-communist periods, it is imperative to learn political language.

And the situation is the same today. The political processes that are taking place in Ukraine also require development in this direction, the importance of the political word is growing. And this significantly changes the attitude towards the politics, the political system, the society, and so on. A politician must be able to speak political rhetoric, political language, express own opinions in such a way that the society understands politics. Democratic political discourse requires the openness of previously hidden aspects which happens through the word. 
It is openness and publicity that lead to the politicization of social life. The word itself is an instrument of the enlightening role of democratic political discourse, which determines not only the limits of political thinking but also the reality of political action. The essential content of democratic political discourse becomes understandable only when the word is not merely a quantity of facts or evidence. Linguistic political discourse also contains desires, dreams, some different facts and different forms of human life. Language (speech), especially political, always contains our interpretations of the outside world and evaluative semantic forms regarding real or possible political events. Political ideas and power relations are also captured with the help of language, so democratic political discourse defines various possible forms of political practice.

The degradation of a political regime and the decline of political ideology occur by the degradation of language. Old speech cannot disappear at the same time in any mechanical way. This happens discursively. The key elements of the political language of the Soviet era today are inappropriate in modern society that is open and progressive. It is the language that determines the claims of politicians and at the same time defines one's participation horizons in political discourse.

So, in the opinion of the author, the following features are characteristic of the political language of the modern period: "process intensification of borrowing foreign words and the rather strong slang influence and everyday speech, as well as general stylistic decline in modern political language”. It can be said about "increased aggressiveness of modern political language, active use of confrontational strategies and tactics of linguistic behavior (threats, neglect, discredit, falsehood, labeling, insults, etc.)" ${ }^{30}$. For example, we see some politicians and statesmen express offensive expressions in the political rhetoric today: "populists”, “speculators”, "bastards”.

\section{CONCLUSIONS}

Political language reflects not only the real state of affairs in Ukraine but also its perception in the national consciousness. Reality and its awareness in the social mentality do not always coincide.

It should be agreed with N. Efteni's position who believes that "political manipulation acts as one of the conditions for stable existence of political regimes and allows controlling the personality and his consciousness. Political manipulation tools need to be continually developed and refined as they help the political regimes function steadily. Political manipulation must be planned and organized, as it may entail potential risks to the development of society as a whole. Furthermore, in the author's opinion "it is necessary to

${ }^{30}$ Дяченко О. (2016) Особливості мовно-маніпулятивного впливу за різних типів політичного режиму. Актуальні проблеми політики. Одеса, 58, 29-40. 
actively involve the mass media that effectively disseminates the necessary information and renders the greatest impact on public consciousness" ${ }^{31}$. It can be defined that "cultural and manipulative technologies are inherent in any political regime”,32, although they have their differences and characteristic features.

Thus, in our opinion, the following are inherent for a political language in a democratic mode: dialogue (instead of a monologue under a totalitarian regime) the presence of feedback from the addresser and the addressee of the information; pluralization of communicants' communicative behavior; extensive use of public speeches; increment in the proportion of spontaneous performances; individualization and promotion of subjectivity of the design of thoughts and ideas.

\section{SUMMARY}

This monograph section focuses on the transformation of political language in different types of political regime.

A comprehensive analysis of the political language of the totalitarian model of political communication in Soviet times, in the "transition period" and the democratic model of political communication is performed.

The paper shows what the political communications of various political regimes, in Ukraine, have in common and the exact differences. The influence of political language on public consciousness is investigated.

Attention is focused on the fact that political language reflects not only the real state of affairs in Ukraine but also its perception in the national consciousness.

Thus, the key elements of the political language of the Soviet era today are unsuitable for modern society that is open and progressive. It is the language, that determines the claims of the politicians and at the same time defines own participation horizons in political discourse.

${ }^{31}$ Єфтєні Н. (2015) Політичне маніпулювання: особливості застосування. Актуальні проблеми політики, 56, 234-241.

32 Дяченко О. (2016) Особливості мовно-маніпулятивного впливу за різних типів політичного режиму. Актуальні проблеми політики. Одеса, 58, 29-40. 


\section{REFERENCES}

1. Баранов А. (2001) Введение в прикладную лингвистику. М., 360.

2. Беккер К. (2004) Словарь технической реальности: Культурная интеллигенция и социальный контроль. М., 65.

3. Грачев М. (1996) Актуальные проблемы политической науки. M., 188.

4. Дяченко О. (2016) Особливості мовно-маніпулятивного впливу за різних типів політичного режиму. Актуальні проблеми політики. Одеса, 58, 29-40.

5. Єфтєні Н. (2015) Політичне маніпулювання: особливості застосування. Актуальні проблеми політики, 56, 234-241.

6. Земская Е. (1996) Клише новояза и цитация в языке постсоветского общества. Вопросы языкознания, 3, 23-31.

7. Оруэлл Д. (2013) Роман. Скотный Двор. Сказка-аллегория. M., 412.

8. Почепцов О. (1987) Коммуникативные аспекты семантики. Киев, 129.

9. Серио П. (1999) Как читают тексты во Франции. Квадратура смысла. М., 12-53.

10. Токвиль А. де (1992) Демократия в Америке. М., 560.

11. Фуко М. (1997) История безумия в классическую епоху. СПб., 576.

12. Щербинин А. (1999) «С картинки в твоем букваре» или Аз, Веди, Глагол, Мыслете и Живете тоталитарной индоктринации. Полис, 1, 116-136.

13. Fairclough N. (1989) Language and Power. N.Y., 259.

Information about the author: Diachenko O. V.,

Candidate of Political Sciences, Senior Lecturer at the Department of Political Science, Odessa I. I. Mechnikov National University 2, Dvorianska str., Odessa, 65082, Ukraine 


\section{COMMUNICATIVE MECHANISMS IN THE SYSTEM OF POLITICAL RESPONSIBILITY OF MODERN SOCIETY}

\section{Dunayeva L. M.}

\section{INTRODUCTION}

In today's world, the problems of becoming an information society are becoming more and more relevant. The significant challenge is that the social basis of political power is gradually being transformed and mediated through mass communication processes. In these circumstances, the study of the phenomenon of political responsibility becomes especially relevant, especially in the transitional periods of society, which are usually accompanied by a crisis of trust between the public and the authorities, the need to find mechanisms to increase the effectiveness of the process of political decisionmaking and implementation, ensuring sustainable development.

Political responsibility is one of the public institutions that are transformed by the influence of communication processes. This is due to the changing fundamentals of political interaction between public authorities and civil society institutions. In today's world, people's behavior is increasingly influenced by information messages that determine the political agenda.

On the other hand, societies seeking to exercise power in a democratic way face the problem of rationally restricting the individual's democratic freedoms for the benefit of the public good. Awareness of the growing need for political participation of individuals in the democratic process leads to the mythologization and hyperbolization of the degree of their participation in the process of socially significant decisions of the information age, enhances the political responsibility of the institutions of civil society, of every citizen.

The issue of political responsibility is linked to a wide range of issues that are relevant to all spheres of public life and aspects of socio-political interaction, one of which is the communicative dimension. Its solution requires exploring the communicative mechanisms of political responsibility and their transformations in the context of democratic transformations of government and society.

The purpose of the article is to identify the communicative mechanisms of political responsibility and their transformation in the context of democratic transformations of government and society. To achieve this goal it is necessary to solve the following research problems:

- to explore the evolution of scientific approaches to understanding the idea of political responsibility and the stages of its formation in the history of political thought; 
- to determine theoretical and methodological foundations of the study of political responsibility;

- to investigate the political responsibility of the authorities of the modern and postmodern era;

- to consider communicative factors influencing the level of political responsibility;

- to explore the basic principles of accountability of democratic power;

- to analyze the process of institutionalization of political responsibility in Ukraine.

\section{The evolution of scientific approaches to understanding the idea of political responsibility}

At different historical stages of society development, the phenomenon of responsibility was explained from the standpoint of mythological ideas, religious outlook, ideological doctrines, and scientific paradigms. In the history of scientific thought different ways of substantiating the idea of responsibility are distinguished, among them the theological concept of responsibility, social, moral, political, professional concept of responsibility.

In archaic societies, responsibility was explained in the language of myth, and its basis was the transcendental will of the gods, the elements, the primary sources. In Greek thought, the problem of responsibility is interpreted in the context of philosophical knowledge.

In the Roman Empire, the emphasis was placed on the legal component of political and civil responsibility (Cicero, Seneca, etc.). At the stage of the Middle Ages, the theological doctrine of responsibility was substantiated by P. Abeliar, Avhustyn Blazhennyi, Toma Akvinskyi, Marsylii Paduan-skyi, Helasii, V. Okkam and others, who insisted that the responsibility of man to God does not depend on origin, power, and social position.

During the Renaissance, the problem of responsibility returned to the earthly dimension - responsibility for one's own success, the state, and the subjects. One of the theorists of this understanding of responsibility was $\mathrm{N}$. Machiavelli, who substantiated the proposition that politics does not need the support and approval of morality or religion. In the period of modern times (XVII - XVIII centuries) the problem of relations between the individual and the state was solved in the theories of "natural rights" and "social contract". These theories were developed by T. Hobbs, Huho Hrotsii, D. Didro, T. Dzhefferson, I. Kant, D. Lokk, T. Pein, Zh. - Zh. Russo, B. Spinoza and others. These concepts combine political responsibility and legal (constitutional) responsibility.

Further interpretations of the phenomenon of responsibility in the history of political thought are linked to the development of these approaches, as well as the theories of elites (H. Moska, V. Pareto, R. Mikhels), political power and bureaucracy (M. Veber), and political culture (H. Almond, S. Verba). 
Since the Renaissance, the concept of responsibility has been linked to moral doctrines. The level of political responsibility was directly dependent on the moral principles professed by politicians and citizens, and the ability to take responsibility indicated the level of moral development of the individual. In the moral doctrine of political responsibility, the principles, values and norms that were formed in the process of political activity were conceptualized, summarized and reflected in the form of ethical theories.

During the modern and postmodern days, the problem of governmental responsibility holded a special place. In the process of modernization, political responsibility was linked to the whole system of policy making and implementation. This implied certain consequences for certain actions of the authorities: political (election loss, so-called "retrospective responsibility") and legal (defined by law, in particular - constitutional responsibility).

The mechanisms of exercising the responsibility of the modern-day authorities include the dissolution of parliaments, impeachment, the recall of individual parliamentarians, election procedures, legal norms, resignation of governments, freedom of speech in the media, the right to criticize the authorities.

In the second half of the twentieth century, in the process of deconstruction of logocentrism, power and law, politics and science, a reinterpretation and concept of political responsibility took place. Postmodernization implied a transition from the industrial model of the state "labor - state capital" to the postmodern model "consumer - state - producer", which meant shifting responsibility from vertically organized and hierarchical structures to horizontal interaction.

\section{2. "Theoretical and methodological foundations of the study of political responsibility"}

The classification of types of responsibility depends on the sphere of social activity, in connection with which political, moral, social, legal, professional responsibilities are distinguished.

The political analysis of interpretations of political responsibility presupposes its implementation in different and interrelated dimensions: responsibility of public authorities and, above all, of the state before citizens; responsibility of different branches of government; responsibility of political parties to citizens; political responsibility of citizens. The main approaches to the consideration of political responsibility are constitutional-legal, political and social-moral approaches.

Ukrainian scientist Tarasenko T.M. summarizing the political responsibility existing in the special political science literature, writes that the common characteristics of political responsibility, which are presented in contemporary publications, include the determination that this responsibility: 
- for the purposeful use of power (political representation);

- fulfillment or non-fulfillment of the proclaimed programs, obligations, promises;

- whether or not the promises made by political figures (entities) are consistent to their real activity, social protection of the population, damage caused to society through improper activity, development of society, realization of citizens' rights;

- the responsibility of the political opposition for the harm caused to society through inappropriate activities;

- election of representatives of public authorities by citizens at elections;

- the correspondence between the real problems in society and their awareness of the reforming politicians;

- the inability of public authorities and officials to develop and implement policies aimed at the progressive development of society;

- the misappropriation of statutory functions and powers by policy entities;

- political, economic and social consequences for citizens of decisions and actions of public authorities;

- actions or decisions that have had adverse effects on the community, individual groups or individuals;

- improper exercise of the power given by some or other persons to the people as the sole source of power ${ }^{1}$.

Political responsibility stems from the peculiarities of political relations and the rules that govern them. The peculiarity of political responsibility lies in the fact that its essence is a negative assessment of the political misconduct of the actor by the public.

In legal science, specific responsibility is allocated - constitutional (or constitutional-legal), a significant contribution to the research of which has been made by Ukrainian scientists Pohorilko V.F., Todyka Yu.M., Frytskyi O.F., Shapoval V.M. and others.

At the present stage of political development, the basis of the process of political responsibility formation is the full functioning of democratic political institutions, the election of officials in free elections, the rule of law, equal access to the media, and the autonomy of public organizations. The work of such foreign authors as H. Almond, S. Verba, L. Daimond, D. Darendorf, R. Dal, A. Leipkhart, D. Rastou, Dzh. Sartori, O. Soloviov, Y. Shumpeter and

${ }^{1}$ Tarasenko M. Poniattia politychnoi vidpovidalnosti $\mathrm{v}$ konteksti naukovykh doslidzhen iz mistsevoho samovriaduvannia/ Teoriia ta praktyka derzhavnoho upravlinnia/ Kharkivskyi rehionalnyi instytut derzhavnoho upravlinnia NADU pry Prezydentovi Ukrainy. \# 3 (58)/2017. - S. 3. 
others. Among the Ukrainian researchers are the works of B. Andresiuk, Ye. Bystrytskoho, V. Horbatenko, A. Kolodii, V. Kremen, M. Orzikh, F. Rudycha, S. Riabov, Yu. Shemchushenko, D. Yakovlev and others.

These authors have developed such theories of responsibility as communicative theory of responsibility, technocratic theory of responsibility, socio-psychological theory of responsibility, regulatory theory of responsibility, normative theory of responsibility, theory of individual responsibility, functional theory of responsibility and legal theory of responsibility. Among these are political theories in which responsibility is divided into retrospective and prospective.

In the course of the evolution of a democratic political system and a rule of law, an understanding of political responsibility as a communicative phenomenon is formed. The communicative component of the process of political responsibility formation is constructed in the course of interaction between government and society (vertical interaction), between authorities (constitutional and legal responsibility) and civil society institutions (horizontal interaction). The basis of political responsibility for this understanding is not only the activities of the authorities, but also the relations between the informed citizens and the authorities. In this theory, the emphasis is on the fact that in today's context these relations are mediated by the information space, in particular - by the activities of the media, which have played an extremely important role in the electoral process in virtually all countries of the world, regardless of the particularities of their political regime.

At the present stage, communicative mechanisms of political responsibility formation play a decisive role. This is driven by the development of information technology, the mediation of the political process, and the growing influence of Internet communications on political reality. In the process of forming communicative mechanisms of political responsibility, democratic norms of state responsibility are inferior to the principles of the autonomy of the administrative sphere, and instead of the traditionally inherent to the civil service management principle, the partnership model is approved.

Political responsibility in communicative interaction between government and society is manifested in individual and collective forms. Society has a large arsenal of means that can be used as sanctions against power actors: nonviolent protest methods, civil disobedience, lustration, restriction on political rights, and finally, the so-called "political death" of the actor. Such sanctions can be applied to both authorities and opposition politicians.

In today's context, political activity begins with the process of interpretation of information, and the space of political interaction is the information message of the media, which in some way influence the formation of public opinion, structure and rules of political game. These processes also 
fully relate to the phenomenon of political responsibility. The communicative dimension of political responsibility lies in the general, agreed definition of the essence of the relationship between political actors and society, which is influenced by the activities of the media and accepted by the majority of participants in the course of communication.

Modern-day communication, mediated by technological innovation, is transforming the institution of political responsibility and creating new challenges for democracy. For the specific area of political interaction between government and citizens, which is a political responsibility, factors such as changing the system of representation of civic interests in accordance with the requirements of the media format and creating new forms of communication in the sphere of public authority are important. At the same time, globalization creates new challenges for government accountability, such as the need for subsidiarity, changes in the functions and scope of responsibility ("boundaries" of responsibility) of the nation-state, the emergence of new global political actors (TNCs, international nongovernmental organizations, supranational authorities, etc.).

\section{Communicative factors influencing the political level responsibility in democratization}

The evolution and current state of political responsibility formation in modern Ukrainian society is largely determined by the Soviet heritage, the tradition of power-society interaction. From the point of view of "MarxismLeninism" political responsibility was considered as a component of the constitutional guarantee of popular sovereignty. Thus, the adoption of the Constitution of the USSR of the Brezhnev era was considered "a new stage in the unfolding of socialist democracy and the responsibility of the Soviet people for the future." In this case, people's sovereignty was defined as the supremacy and authority of the people, and the concept of "people's sovereignty", "democracy", "democracy" as inseparable from socialism.

The Soviet system was characterized by the extreme degree of categorization, monopolization and centralization of all spheres of public life, which led to the creation of a space of irresponsibility in relations between citizens and the authorities, and formed an appropriate political culture, which is inadequate for the system of political democracy.

In today's transitional society, political responsibility is characterized by particular characteristics. In the process of democratization of society and government, the responsibility of politicians and citizens is manifested primarily in the course of election campaigns, and the phenomenon of "decisive elections" is emerging. The responsibility of politicians during this period is retrospective, and is the ability of civil society to remove from power in the election political parties and forces that do not carry out their election 
programs. This is exactly what happened during the 2019 presidential and parliamentary elections. The results of these elections were a clear demonstration of the political responsibility of former government officials, the head of state, parliamentary coalition, political elites and leaders for political decision-making and implementation, political responsibility of the media and civil society institutions. Real political accountability of political actors is not possible without a developed civil society.

There is a crisis of responsibility, which is manifested most in the moral and professional plane, and is in the absence of adequate value guidelines for the needs of modern social development, the lack of democratic traditions of the dialogue between the authorities and society, the willingness to listen to the moral authorities (like V. Havel, A. Sakharov).

The notion of responsibility in the system of public power depends on the specific functions and powers of the government, parliament, president, local authorities, etc. The general trend is that the role of government is increasing, especially in parliamentary and semi-presidential republics. In parliamentary countries, the formation of a government is carried out by a party or coalition of parties that form a parliamentary majority. Presidential form of government is characterized by the fact that the President heads the government, actively uses its right of legislative initiative, issues its own acts that contribute to strengthening the position of the government in the system of higher authorities. The political responsibility of the government has such a specialty as collegiality.

Political responsibility comes in the form of political and politicallegal sanctions applied to political subjects: negative public assessment in political elections, public mistrust, initiation of the procedure of applying political-legal sanctions according to law, resignation, or deprivation of authority of the subject politicians, refusal to register for the elections, cancellation of state registration of a political party.

Features of political responsibility in modern society are to reduce the role of ideologies, the transformation of political parties into «voting machines», the destruction of communication between the cells of parties and local communities, the dominance in the political space of indirect forms of political communication, the mediation of politics, insufficient development of political parties and effectiveness of civil society institutions, imperfection of legal procedures for implementation of the principle of responsibility.

Among the factors influencing the level of political responsibility should be identified such components as moral and constitutional law. Political responsibility is exercised in the sphere of political activity, and its level is connected with the type of political regime, political activity of citizens, activity of independent mass media, political consciousness and culture, etc. Political responsibility combines two forms: the response of 
society to the actions of politicians and the response of political actors to the demands of society. Therefore, responsibility in the modern world is a special communicative type of interaction between society and government. In modern conditions, the necessary factors of political responsibility formation are the responsibility of the media, the treatment of information as an important public resource, not as a commodity, and the independence of the mass media from public authorities. There is an urgent need to establish ongoing links, communication channels between public authorities and civil society institutions in order to enhance political accountability. This applies not only to vertical communications (state - society), but also to horizontal communications between different social groups. In the first and the second case, the activity of the mass media, whose task is to provide timely and qualitative information to the stakeholders, is extremely important. Thus, the scope of political participation of citizens in politics expands, and accordingly - the mechanism of political responsibility changes. The communicative interaction of modern times, mediated by technological innovations, is transforming the institution of political responsibility and creating new challenges for democracy.

\section{4. "Institutionalization of Political Responsibility in Ukraine"}

The main directions of forming an institution of political responsibility at the present stage of political development of Ukrainian society are to improve the legal mechanisms for ensuring accountability and to increase the role of civil society in the implementation of the principles of political responsibility.

The radical changes of recent decades that have taken place in the world require a revision of the content of political responsibility and the legal mechanisms for securing it. In modern Ukrainian society, there is a process of institutionalization of qualitatively new legal institutions (e.g. NACBU, NAPC) aimed at overcoming the phenomenon of corruption, which has become widespread in the sphere of Ukrainian politics. These institutions should significantly strengthen the mechanisms of constitutional liability and, above all, in the field of politics.

Constitutional responsibility is a system-forming element of the system of protection of constitutional rights and relations. The Constitution defines the basic rights and duties of the authorities and citizens, the balance of power, the division of areas of responsibility between the center and the regions, the executive, legislative and judicial branches of state power.

The main institutional subject of political responsibility is the state, as it is the main subject of public authority in society. The state bears political responsibility to citizens whose community acts as a civil society in relation to the state. The political responsibility of the state to civil society is realized as 
the responsibility of the elected higher bodies of state power, which are the parliament and the president. Elections and referendums are the main institutional means of realizing such a responsibility in today's democratic society ${ }^{2}$.

Political responsibility becomes a determining factor in the modernization type of political development. For the creation of mechanisms of political and legal accountability in post-communist Ukraine, the draft Law «On Political Responsibility» (registered in the Verkhovna Rada of Ukraine on April 9, 2010 by People's Deputy M. Papiiev), which, unfortunately, was subsequently withdrawn from registration was important. The further political practice of Ukrainian society is increasingly providing arguments for the need to adopt a law on constitutional liability, which would become a significant deterrent to the irresponsible activities of public authorities and politicians.

Regarding the system of organization of state power, the factors of its irresponsibility include centralization of power, remoteness of the center of decision-making from local communities, underdeveloped local selfgovernment, lack of authority to solve local problems, low efficiency of decision-making and implementation of political decisions, lack of transparency of government, closedness the mechanism of decision-making and implementation of power decisions, the nomination of the functioning of certain political institutions and the mechanisms that should provide articulation of interests and political responsibility, conservation and restoration of undemocratic inherently political institutions and practices.

Improving the effectiveness of political relations, their qualitatively new meaningful content is possible in the presence of developed institutions of civil society, which perform the function of controlling the activities of the authorities. Self-organization of citizens, their ability to act together and involvement of civil society in the political process are at the forefront.

In the process of democratic transition, one of the important factors is the responsibility of civil society. It is becoming increasingly clear that the hindrances to the realization of the tasks of civil society in the implementation of democratic principles of political responsibility are the main factors: paternalism formed by years of totalitarian and subsequently authoritarian domination, economic factors related to the complexity of market reforms, political ideology and political ideology, major community groups, etc.

It is impossible to develop political responsibility without a developed civil society, which performs the functions not only of controlling the actions of the public by the public, but also of formulating rational alternatives for social development, dialogue with the authorities, protecting the interests of citizens' associations. In the process of forming political responsibility, one of the main problems is the correlation of social and state foundations

${ }^{2}$ Malkina H. Demokratiia i politychna vidpovidalnist. Suchasna ukrainska polityka. Polityky i politolohy pro nei. K., 2010. Vyp. 21 (36). S. 26. 
(interaction between civil society and government), social and political regulators (public associations and political parties).

A special aspect of political responsibility is the role of the nationbuilding people, their awareness of their history and future. The Ukrainian scientist V. Toryanik rightly draws attention to this problem, who writes: «The people as a whole are not criminals, just as they are not immoral, but the collective political responsibility cannot be removed from the people, it is always on them and there's nowhere to hide from it. This responsibility lies in the fact that each of the individuals forming the nation experiences the consequences of the actions of the politicians and citizens of the state under whose authority it is and under the order of which it is. Everyone is jointly and severally responsible for the way they are governed» ${ }^{3}$.

Political responsibility is also measured in the subjective forms of human activity in the political sphere. It is pointed out by researcher R. Zhmudsky, who notes that the subjectivity of political responsibility in public administration is also manifested in the fact that such factors as the level of political and legal culture of the population (including the proper level of knowledge about the content of government policy, local authorities and self-government), the development of political institutions and structures of civil society, the ability of citizens to consciously, rationally evaluate the activities of governmental structures, trust in state institutions, and expectation of fair and careful consideration by the representatives of the authorities of the issues addressed to them by citizens ${ }^{4}$.

Political responsibility is a system of political interactions between the people as a bearer of sovereign power, civil society and public authority, which is intended to express the will of the people through state sovereignty. The level of political consciousness, political culture, system of common civilizational, basic values, a qualitative system of communication mechanisms should define and direct the form and content of relations between the authorities and the people, their responsibility for the future of the country. In the system of this interaction between public authority and civil society, communication mechanisms play an increasingly important role, in the structure of which the media play a dominant role and, at the same time; acquire the status of an extremely important factor in the political accountability mechanism of modern democratic society.

${ }^{3}$ Torianik V. Vzaiemna politychna vidpovidalnist derzhavnoi vlady i hromadia-nyna v suchasnii pravovii derzhavi: Avtoref. dys. kand. polit. nauk: 23.00.02. Dnipropetrovsk, 2006. S.17.

4 Zhmudskyi R. Politychna vidpovidalnist u derzhavnomu upravlinni/ Zbirnyk naukovykh prats Natsionalnoi akademii derzhavnoho upravlinnia pry Prezydentovi Ukrainy. 2011. S. 205-206. 


\section{SUMMARY}

The evolution and tendencies of development of communicative mechanisms of political responsibility are considered in the article, its peculiarities and specific features are analyzed.

It is determined that communicative mechanisms of political responsibility are formed in the process of interaction between the authorities and the society, between the authorities and the institutions of civil society. It is substantiated that in modern conditions political interaction is mediated by the development of information technologies, the mediation of the political process and the growing influence of Internet communications on political reality.

The place of political responsibility in the process of democratic development is analyzed. It is determined that political responsibility becomes a determining factor in the modernization type of political development. The level of responsibility is determined both by the activities of governmental institutions and by the development of civil society, the availability of independent media, regular and free elections.

\section{REFERENCES}

1. Zhmudskyi R. Politychna vidpovidalnist u derzhavnomu upravlinni..Zbirnyk naukovykh prats Natsionalnoi akademii derzhavnoho upravlinnia pry Prezydentovi Ukrainy. 2011. S. 198-207. URL: www.irbis-nbuv.gov.ua/cgi-bin/irbis_nbuv.

2. Malkina H. M. Demokratiia i politychna vidpovidalnist. Suchasna ukrainska polityka. Polityky i politolohy pro nei. K., 2010. Vyp. 21(36). S. 23-32.

3. Tarasenko M. Poniattia politychnoi vidpovidalnosti $\mathrm{v}$ konteksti naukovykh doslidzhen iz mistsevoho samovriaduvannia. Teoriia ta praktyka derzhavnoho upravlinnia. Kharkivskyi rehionalnyi instytut derzhavnoho upravlinnia NADU pry Prezydentovi Ukrainy. № 3 (58)/2017. S. 1-8.

4. Torianik V. Vzaiemna politychna vidpovidalnist derzhavnoi vlady i hromadianyna v suchasnii pravovii derzhavi: Avtoref. dys. kand. polit. nauk: 23.00.02. Dnipropetrovsk, 2006. 20 s.

Information about the author: Dunayeva L. M., Doctor of Political Science, Professor, Odesa National I. I. Mechnikov University 2, Dvorianska str., Odessa, 65082, Ukraine 


\section{ENSURING NATIONAL SECURITY OF UKRAINE UNDER THE CHANGE OF INTERNATIONAL SECURITY ENVIRONMENT}

Hedikova N. P.

\section{INTRODUCTION}

Extensive modernization processes in the second half of the twentieth century, especially in its 80s, spread around the whole bipolar world and led to the creation of a new geopolitical situation, which confirmed the unipolar orientation of the world development and marked the establishment of a new type of world community on a global scale. It raised hope that society would be free from all kinds of conflicts and contradictions, and that the internal, interstate and global problems facing humanity would be solved peacefully, taking into account the national interests of each subject of international relations and on the basis of generally recognized norms and principles of international law. However, the economic, social and political changes brought about by the global transformation of modern society in the last two decades have deepened the dependence of some countries on the interests of other countries and fluctuations in the global political, financial and economic situation and acted as factors of economic and political confrontation between developed countries. These trends, firstly, have determined the vectors for the formation of a multipolar world, and secondly, they clearly show an increase in the level of global threats and instability.

Humanity has existed, exists and will continue to exist in the area of constant threats, the source of which is the multi-scaled natural and anthropogenic processes. Therefore, the issue of peace, stability and security is relevant to all states at any period of their existence. But with the change of epochs, generations and technologies, the content of the very concept of security, the means and organizational measures used to ensure it, the conceptual approaches to reforming the security sector management system, the directions and mechanisms of their implementation are changing over time. This is due both to the fundamental changes in the nature of international and interstate relations and to the achievement of scientific and technological progress.

The fact that global processes are the main source of social transformation makes modern epoch so special. It is the global changes that have occurred at the turn of the last two centuries that have influenced not only the specifics of the development of the world system as a whole, but also all spheres of life of the society, have become one of the most relatable 
features of the modern era. It is around them that all the components of the process of development of civilization revolve, and it is they that determine its present state.

The ongoing processes have raised the issue of international and national security as one of the global problems of humanity.

\section{Real and potential threats to international and national security}

In the current circumstances of global transformations and a new world order, the paradigm of the existence of the world has changed, and thus new concepts have emerged to interpret the notions of «international security» and «national security». Meanwhile, the analysis of scientific literature has shown that understanding of their essence in the context of modern research approaches is determined ambiguously.

Summarizing scientific approaches, it can be noted that international security is stability and secure and sustainable development in the world, while creating the conditions for coordination of relations and interaction between all actors of the security sector. The concept of international security in the modern world is becoming more pervasive and goes far beyond the traditional notion, the essence of which is to maintain territorial integrity of the state by military or diplomatic means, and the threat to lose it comes from another state.

Among the considerable number of scientific approaches to defining the essence of the concept of national security, which in particular characterize its content, the research position offered by the authors of the analytical report «Conceptual Framework for Development of the National Security System of Ukraine» deserves special attention. Thus they have conventionally identified two approaches to interpreting the term: broad and narrow ones. According to the first approach, national security covers virtually all spheres of public life and is regarded as: protecting the vital interests of the individual, society and the state from external and internal threats; or the absence of threats to national values and the vital interests of citizens, society, the state; or a set of factors that provide favorable conditions for the development of the country; etc. The second approach to the definition of the term "national security» narrows its scope and can interpret national security as: the scope of joint efforts of certain types of public policy (the combination of policies may be different, but more often it is about military and foreign policy); or a condition which excludes the threat of war, the threat of the country's sovereignty, its independence and territorial integrity; etc. ${ }^{1}$.

1 Концептуальні засади розвитку системи забезпечення національної безпеки України : аналіт. доп. / О. О. Резнікова та ін. Київ : НІСД, 2015. С. 5. 
Among the numerous attempts to define the concept of «national security of Ukraine», in our opinion, the concept of domestic researchers O. Vlasiuk, S. Pyrozhkov and O. Bielov, according to which this category is understood as «a way of self-preservation of the Ukrainian people, which has reached level of organization in the form of an independent state. This method allows for its free existence and self-development, reliable protection against external and internal threats. National security of Ukraine can be defined as a system of state-legal and public guarantees for the stability of life and development of the Ukrainian people in general, and of every citizen in particular, protection of their basic values and legitimate interests, sources of spiritual and material development from possible real and potential, internal and external threats» ${ }^{2}$.

The purpose of international and national security is to identify the ways of forming a security environment, to create favorable conditions for the development of objects of protection (state, society, people, nation, legal or natural person, citizen and individual) for the maximum satisfaction of their needs and interests, as well as to ensure the required level of protection against various threats based on the activities of the subjects of national security (international community, national society, state, state and international bodies, international and public organizations, officials, citizens and individuals) with the purposeful management of them in the direction of timely detection, prevention, neutralization and elimination of the factors that cause them.

Creating an effective system of international and national security requires an objective assessment of real and potential threats. As practice proves, it is implemented in the following main areas: geopolitical, state, political, military, defense, economic, social, demographic, ethno-political, humanitarian, socio-cultural, intellectual, scientific and technological, energy, food, environmental, cybernetic, judicial etc. The complex analysis of the security situation also takes into account the peculiarities of the development of a particular state and its strategic development goals.

Among the important factors that affect the security situation the most important are: conflict situations, which are based on incompatible interests and aspirations, differences in value systems, goals; disruption of the balance in a certain area or its subspecies; exacerbation of interethnic, interfaith, international and interstate relations.

Currently, there are many threats to the national and international security in the world. However, it should be noted that it is the new system of international relations that is becoming the main criterion for generating a

${ }^{2}$ Власюк О. С., Пирожков С. І., Бєлов О. Ф. Концептуальні підходи до формування системи національної безпеки України / О. С. Власюк. Національна безпека України: еволючія проблем внутрішньої політики : вибр. наук. праці. Київ : НІСД, 2016. С. 23 С. 25. 
large number of threats and challenges of a diverse nature for the global security environment. Thus, Ukrainian researchers O. Vlasiuk and S. Kononenko conceptually distinguished seven major threat factors that are currently being identified globally.

1. Possibility of displacement to the periphery and assimilation. Globalization processes create dangers, bringing new asymmetries, disproportions, and deformations to the structure of modern interstate relations. As a result of globalization processes, the international status of some countries is declining, which displaces them into the periphery of world development and world politics.

2. Regional isolationism and regional imperialism. The processes of regional integration and the formation of regional integration blocs present threats of regional isolation and regional domination. It is a matter of regional fragmentation of the world - the danger of the emergence of closed and maximally isolated from the rest of the world regional groups that compete and oppose each other.

3. Fragmentation of violence and the return of its archaic forms. The historical changes currently taking place in the field of international security give rise to a number of challenges to national security systems, namely: local conflicts and low-intensity conflicts; information intervention, civil and hybrid wars; organized crime in all its manifestations, including terrorism and separatism; the proliferation of weapons of mass destruction. There is a certain class of threats associated with the revival of archaic forms of international relations, such as militant imperialism and the great interstate wars, potentially threatening to detonate the world war.

4. Suspension of market democratization. The advancement of global market democratization may not only suspend, but also suffer a historic defeat, leading to the restoration of aggressive and repressive authoritarianism in some countries and the establishment of corrupt oligarchic democracies in others. And thus, the world will receive new lines of division, embers of conflict, sources of chaos and instability.

5. Erosion of value pluralism. The value pluralism of the modern world can be eroded by two factors - religious and ideological fundamentalism and value fragmentation (sectarian «minorityzation»).

6. Dysfunction of state-building processes. The crisis, or even the failure, of state-building efforts leads to the emergence of inefficient, fragile, dependent states, incapable of independent and self-sufficient existence, which threatens global peace and security.

7. Natural disasters and technological disasters. It is a threat of environmental disasters caused by climate change; the dual threat of global economic decline and the worsening struggle for natural resources caused by their depletion; demographic problems caused by accelerated population 
growth on Earth; technological disasters that are a side effect of any revolution in technology and scientific and technological progress in general ${ }^{3}$.

According to the domestic political scientist S. Teleshun, there are five groups of global risks that will be transformed, but preserve the potential of systemic threats, both to humanity as a whole and to individual regions and states. Thus, the author notes that economic risks are at the forefront: unstable prices for food and energy; unpredictable and speculative fluctuations in world currencies; fiscal crisis; decrease in the value of assets; cyclical manifestations of the crisis in the economies of the dominant three countries; slowing down globalization; stagnation of business administration; limited financial resources and their investments in infrastructure, etc. The second group of risks include geopolitical threats, including: international and not only terrorism; unauthorized proliferation of mass destruction technologies; the critical situation in the «countries of axis of evil» - Afghanistan, Iran, North Korea, Iraq, Israel, Palestine; transnational crime and corruption; the failure of the existing world order. The third group focuses on environmental issues: climate disasters and cataclysms; water shortage; poisoning of the environment; the disappearance of certain representatives of flora and fauna. Social risks: different types of pandemic; migration; new infectious and chronic diseases; humanitarian disasters; worldview conflicts at the level of world cultures and others. And the last group of major risks comprises technological risks: systemic failures of information infrastructure; loss of databases; man-made (technological) disasters; toxic nanoparticles; cyber wars; interference with information privacy space, etc. ${ }^{4}$.

The global risks identified by the authors cited also include, in our view, such destabilizing factors of international and national security as the proliferation of nuclear technologies, uncontrolled migration from third world countries, violation of human rights and fundamental freedoms, and the rights of national minorities, multidimensional manifestations of political radicalism and extremism, the proliferation of new types of drugs, etc.

The results of the analysis of the legal documents of Ukraine and scientific publications on this issue give reason to highlight the following internal threats to national security:

- inefficiency of the national security and defense system;

- inefficient public administration;

${ }^{3}$ Власюк О. С., Кононенко С. В. Національна безпека України: стратегічни виклики, національні інтереси та пріоритети забезпечення / О. С. Власюк. Національна безпека Украӥни: еволючія проблем внутрішньої політики: вибр. наук. праці. Київ : НІСД, 2016. C. 16-18.

${ }^{4}$ Телешун С. О. Глобальні виклики та ризики, які загрожують світу у 2010-2015рр.: місце і роль ООН у цих процесах. Актуальні проблеми міжнародних відносин. 2011. Вип. 96. Ч. I. C. 10. 
- infringement upon state sovereignty, territorial integrity, economic, scientific, technical and defense potential of the state, rights and freedoms of citizens;

- corruption, bribery, merging business and politics;

- low level of provision of military and special equipment and next generation weapons of the Armed Forces of Ukraine, other military formations;

- slow implementation and insufficient financial support for the reform programs of the state's military organization and defense industry associations;

- conflicts in the sphere of interethnic and inter-confessional relations, radicalization and manifestations of extremism in the activities of some associations of national minorities and religious communities;

- manifestations of separatism in certain regions of the country;

- formation of illegal armed groups;

- gunrunning;

- high criminogenic situation;

- structural and functional imbalance of the political system of society, inability of its individual units to respond promptly to threats to national security;

- economic crisis, depletion of financial resources of the state, decline in living standards;

- critical dependence of the national economy on the external markets, low rates of expansion of the internal market;

- the accumulation of public debt and the country's dependence on creditors threatens the stability of the financial system;

of the economy;

- growth of the share of foreign capital in strategic sectors

- «shadowing» of the national economy;

- rising inflation and outpacing wage growth;

- significant increase in energy prices;

- legalization of proceeds of crime, which negatively affects all spheres of public life;

- predominance in the activity of management structures of personal, corporate, regional interests over national ones;

- the crisis of the social protection and the health care system;

- aggravation of the demographic crisis;

- inefficiency of state innovation policy, mechanisms for stimulating innovation activity;

- the outflow of scientists, specialists, skilled labor, young people abroad; 
- illegal migration;

- cybercrime and cyber terrorism, etc.

Real and potential threats to Ukraine's national security may come from outside as well as from within the subject or object of security. Accordingly to it structurally national security consists of many components, which are determined by different spheres of national interests of the individual, society and the state, because they act as prerequisites for the process of designing a state development strategy and its activities in the international arena. Such components are state security, foreign and domestic political, economic, ethno-political, demographic, ethno-cultural, social-humanitarian, scientific-technological, ecological, informational, military-strategic, etc.

Given that international and national security continuously exert mutual influence on each other, it should be noted that these threats at the international and national level are interdependent and determining factor for both security areas. Taking this into account, it is worth agreeing with the opinion of the Ukrainian scientist I. Bilas, who states: «The basic feature of this period is that a lot of potential threats have come to replace the global threat: smaller scale, but quite serious in its consequences for the international peace and stability affecting the interests of many countries» ${ }^{5}$. This is primarily due to the change and complication of social relations, technology, instability in various spheres of life in individual countries and regions, respectively, «confrontation from the world level has shifted to the regional one. It is not regional associations that oppose it, but regional alliances; it is not individual states that are at war, but individual countries. The reasons are the same, the motives are the same and the horrible consequences are the same. This whole new set of contradictions entered into a fierce confrontation with the outdated world security scheme, imposed in $1945{ }^{6}$. For this reason, the interest of the subjects and structures of common security in providing national security with international security is justified.

A fundamental factor for international security is the provision of the public interests associated with the common desire to prevent the threat of self-destruction. At the present stage of its state-building, Ukraine, implementing the tasks of national security and defense, builds up its program of actions on the basis of the combination of national interests with the common ones. At the same time, it should be noted that the decisive role in this matter belongs to the national interests, based on the fact that they are

${ }^{5}$ Білас І. Г. ООН та сучасні виклики і загрози міжнародній спільноті та безпеці в умовах глобалізації. Актуальні проблеми міжнародних відносин. 2011. Вип. 96. Ч. І. C. 37-38.

6 Чекаленко Л. Д. Національна безпека України: система реалізації. Зовнішні справи. 2016. № 11. С. 17. 
intended to ensure the security of the country, its sustainable and progressive development.

Taking it into consideration, we state that it is the national interests that serve as prerequisites for the process of designing a state development strategy and its activities in the international arena. In addition, they define the principles, strategic goals, objectives and mechanisms of securing the vital interests of the individual, society and the state.

\section{State policy of Ukraine in the field of national security}

Security provision is the process underpinning the activity of its subjects, aimed at ensuring the stability, safe and sustainable development of the social environment, preserving and enhancing the spiritual, intellectual and material values of the objects of security, as well as ensuring the necessary level of their protection against all kinds of threats.

The modern transformation of relations, changes in the balance of interests, both at the global and regional level, have led to the corresponding adjustments of Ukraine's foreign policy. The main priority of its foreign policy has become the effective implementation of the European integration strategy, which is linked to significant changes in the content and tactics of its implementation.

Taking into account the new geopolitical realities, our country has clearly defined the priority and strategic tasks of the modern Ukrainian geostrategy in general, and especially the foreign policy course, the essence of which is the implementation of the new foreign policy philosophy of Ukraine, which is aimed at the implementation of European integration aspirations and comprises:

1) Ukraine's Euro-Atlantic integration, which is an integral part of the general course towards European integration, while the content of integration towards NATO and EU structures, while maintaining the strategic goal of membership in these organizations, undergoes certain conceptual and functional changes;

2) continued participation in UN peacekeeping activities considering it an important factor in its foreign policy;

3) implementation of the provisions of the EU-Ukraine Association Agreement, while steadily maintaining its focus on democratic values and building democratic state institutions;

4) creation of effective mechanisms for state involvement in the world political and economic space, in particular in the format of regional models of cooperation $^{7}$.

${ }^{7}$ Аналітична доповідь до Щорічного Послання Президента України до Верховної Ради України «Про внутрішнє і зовнішнє становище України в 2016 р.». Київ : НІСД, 2016. 688 c. 
In the sphere of international security, conceptually, the key task of Ukraine is to ensure the long-term stability of international and, in particular, the European regional system. At the same time, in the foreign policy strategy, Ukraine, given the geographical location of our country, pays special attention to the development of partnerships with the countries of the former Soviet Union, as well as further constructive partnership with the structures of common security, namely: UN, OSCE, CIS, BSEC, European Union, North Atlantic Treaty Organisation (NATO), the countries of Central and Eastern Europe within the framework of the Eastern European Union on all issues and other international organizations whose activities do not contradict or threaten national interests of Ukrainian people and humanity.

The system of international law and the system of domestic law are closely linked, due to the fact that states are its main subjects.

The sources of international law that directly regulate relations connected with the maintenance of international security are such fundamental and universally recognized principles as respect for the sovereignty of states and prevention of interference in their internal affairs, equality of states, selfdetermination of peoples and nations, non-discrimination, respect for human rights and freedoms.

Article 9 of the Constitution of Ukraine states: «Running international agreements, consent, on obligatory of which given by Supreme Soviet of Ukraine, are part of national legislation of Ukraine. Conclusion of international agreements which conflict with Constitution of Ukraine, possible only after bringing of the proper changes to Constitution of Ukraine» ${ }^{8}$. Considering this, the principles and rules of international law set out in the international legal instruments ratified by Ukraine are part of its legal system.

Having joined the international security system, Ukraine has signed a number of international legal acts on cooperation and peacekeeping in an international and regional format: Treaty establishing the Commonwealth of Independent States (1991); Memorandum on Security Assurances in connection with Ukraine's accession to the Treaty on the Non-Proliferation of Nuclear Weapons, so called Budapest Memorandum (1994); The Comprehensive Nuclear-Test-Ban Treaty (1996); The Treaty on Friendship, Cooperation, and Partnership between Ukraine and the Russian Federation (1997); The Treaty on the Non-Proliferation of Nuclear Weapons (1967); Declaration on the strategic partnership between the Russian Federation and Ukraine (2012) and others. In each of them, it is emphasized that the implementation of the provisions set out in them will be carried out on the basis of generally recognized principles of international law, the inalienable

${ }^{8}$ Конституція України : офіц. текст. Відомості Верховної Ради України. 2019. № 9. Ст. 50. 
right of all participating countries to respect state sovereignty and independence, territorial integrity and inviolability of existing borders.

However, despite its commitments, the Russian Federation has repeatedly attempted to violate Ukraine's territorial integrity and its sovereign right to self-determination, and at the beginning of 2014, it committed aggression against Ukraine.

Since then, in order to resolve the conflict between Ukraine and the Russian Federation, top leadership of the Ukrainian state, representatives of foreign states, politicians and experts have expressed the need to return to the «Budapest format».

Ukraine regards the Budapest Memorandum as an important international instrument for its security provision, thus, the Ministry of Foreign Affairs of Ukraine, based on paragraph 6 of the memorandum in 2014, and subsequently officially addressed the signatory states demanding urgent consultations aimed to ensure full compliance with those obligations. Officially, neither party has abandoned their implementation. Moreover, the USA and Great Britain contributed to the protection of Ukrainian interests by raising the issue of Ukraine's security at the UN Security Council, as well as through the system of sanctions against the Russian Federation.

The prospect of working within the «Budapest format» depends on whether the Russian Federation will join the negotiation process and fulfill its obligations. In the meantime, we can state the fact that, as domestic history shows, there is no such agreement with Russia that it would break sooner or later. The Russian Federation violates not only the agreements enshrined in the Budapest Memorandum, but also the basic principles of the OSCE Final Act, the UN Charter, the principles and rules of international law. Its actions are a challenge not only for Ukraine but also for international law and the world community as a whole.

The aggressive actions of the Russian Federation against Ukraine violate all norms of international relations and international law and reiterate the fact that, firstly, «a country that is not part of a reputable international structure is often not sufficiently respected by the so-called great states and international organizations, and even disregard the interests of a single state that can only count on its own strength» ${ }^{9}$, secondly, these international instruments do not regulate binding mechanisms and instruments for guaranteeing the security of the participating states and counteracting responses to some threats to their sovereignty and independence, do not prescribe clear procedures for protection against breaches of security guarantees.

${ }^{9}$ Тімкін І. Система національної безпеки України: стан та перспективи розвитку. Нова парадигма. Київ : Вид-во НПУ ім. М. П. Драгоманова, 2015. Вип. 128. С. 165-167. 
All of the mentioned above led Ukraine to raise the issue of dropping the country's non-aligned status.

Under these conditions, the task of re-assessing Ukraine's place and role in the modern world in order to achieve a «new foreign policy positioning of Ukraine in the world in the face of instability of the global security system ${ }^{10}$ becomes extremely urgent. In this regard, Ukraine, being an active participant of international relations and, in particular, partnerships in the field of security, gives an objective assessment of the factors that threaten global international stability and adversely affect the security environment of Ukraine.

Currently the basic normative documents in Ukraine, which according to the provisions of the Constitution of Ukraine, aimed at building the environment for ensuring national security of the country are the following: the Law of Ukraine «On National Security of Ukraine» (21.06.2018) ${ }^{11}$, the Law of Ukraine "On the Principles of Domestic and Foreign Policy» $(01.07 .2010)^{12}$, National Security Strategy of Ukraine (26.05.2015) ${ }^{13}$, Concept of development of the security and defense sector of Ukraine (14.03.2016) ${ }^{14}$.

The first document sets out the bases and principles of national security and defense, the goals and fundamental principles of public policy aimed at protecting national interests and guaranteeing the public and every citizen protection against threats. The second document sets out the basic principles and ways of implementing a balanced, focused domestic and foreign policy of Ukraine and the effective implementation of a set of concerted measures to protect national interests in different spheres of life. The third document officially endorses the system of principles, strategic priorities and goals, tasks and mechanisms for securing the vital interests of the individual, society and the state in a changing and contradictory global space in the long run. The fourth document defines the main directions and tasks of development of the security and defense sector of Ukraine in the medium term, formed on the basis of the assessment of the security environment and financial and economic capacities of the state.

10 Про Стратегію національної безпеки України : Указ Президента України від 26.05.2015 № 287/2015. URL: http://www.rnbo.gov.ua/documents/396.html.

${ }^{11}$ Про національну безпеку України : Закон України від 21.06.2018 № 2469-VIII. Відомості Верховної Ради. 2018. № 31. Ст. 241.

12 Про засади внутрішньої і зовнішньої політики : Закон України від 01.07.2010 № 2411-VI. Дата оновлення: 08.07.2018. URL: http://zakon2.rada.gov.ua/laws/show/2411-17 (дата звернення: 13.09.2019).

13 Про Стратегію національної безпеки України: Указ Президента України від 26.05.2015 № 287/2015. URL: http://www.rnbo.gov.ua/documents/396.html.

${ }_{14}$ Про рішення Ради національної безпеки і оборони України від 4 березня 2016 року «Про Концепцію розвитку сектору безпеки i оборони України»: Указ Президента України від 14.03.2016 № 92/2016. URL: http://www.president.gov.ua/documents/ 922016-19832. 
Ways to reach the country's most appropriate place in the global security system are theoretically substantiated in the updated version of the National Security Strategy of Ukraine ${ }^{15}$. It attempted to take a new, much more comprehensive look at the phenomenon of security, its internal content and it identified the main priorities of state policy in the field of guaranteeing the national security of the state.

Based on the analysis of the mentioned normative document, it can be stated that global processes, actual threats caused by the changes in the foreign and domestic security environment of Ukraine, occurring since 2014, actualized the need to develop a «completely new state policy aimed at effective protection of national interests in economic, social, humanitarian and other fields, comprehensive reform of the national security system and the creation of an effective security and defense sector of Ukraine» ${ }^{16}$. Thus, the most important priority of the national security policy of the country is «minimization of threats to state sovereignty and creation of conditions for restoring the territorial integrity of Ukraine within the internationally recognized state border of Ukraine, guaranteeing the peaceful future of Ukraine as a sovereign and independent, democratic, social, state of law» ${ }^{17}$.

Therefore, the main directions of state policy in this area, defined in the National Security Strategy of Ukraine, are the following:

- restoration of territorial integrity within the internationally recognized state border of Ukraine;

- creating an effective security and defense sector and enhancing the country's defence capability;

- reforming and developing intelligence, counterintelligence and law enforcement agencies;

- reforming the public administration system and improving anticorruption activities;

- integration into the political and economic structures of the European Union and the development of a special partnership with NATO;

- implementation of foreign policy activities based on their own capabilities, including the policy of European and Euro-Atlantic integration and at various levels - global, regional, subregional ${ }^{18}$.

Successful completion of the tasks is possible provided the unity and capacity of the subjects of activity in the field of security, the powers, organization and order of activity of which are determined by the current legislation. State and public institutions, based on their organizational,

15 Про Стратегію національної безпеки України : Указ Президента України від 26.05.2015 № 287/2015. URL: http://www.rnbo.gov.ua/documents/396.html.

${ }^{16}$ Ibid.

${ }^{17}$ Ibid.

${ }^{18}$ Ibid. 
functional and resource capacity, are primarily responsible for guaranteeing the sovereignty, territorial integrity, well-being and comprehensive security of citizens.

In early 2014, it became apparent that Ukraine's national security system was not ready to effectively confront new types of threats at the present stage of its development. Thus, the document «Analysis of the state policy in the field of national security and defense of Ukraine», executed by a group of Ukrainian experts with the support of the Reanimation package of reforms, states: «The authorities, all parts of the military organization of Ukraine, local self-government bodies, the unified system of civil defense, national economy have not been prepared for the transition from peaceful to martial law and repel armed aggression... The actions of the subjects of national security of Ukraine at the beginning of the aggravation of the military-political situation were not effective. Efficiency of management's decision-making in the field of national security was low, which did not provide timely response to new threats. The absence of a permanent modeling and forecasting mechanism as a basis for decision-making did not allow us to take a proactive role» ${ }^{19}$.

In addition, in our opinion, this was due to the fact that the whole system of national security lacked adequate institutional support and delimitation of the areas of competence of the direct implementers of measures in this matter, their unprofessional actions, insufficient resources and their inefficient use, appropriate legal mechanisms of management in this area were absent, also it lacked persistence in the decisions and responsibility for the results of their practical implementation.

At present, the country's government, objectively evaluating the state of this system, is taking comprehensive steps to reform it. An important step in this direction was the adoption of the Sustainable Development Strategy «Ukraine - 2020» of $12.01 .2015^{20}$ and the National Security Strategy of Ukraine of $26.05 .2015^{21}$. These strategic documents have become the basis for comprehensive reform and development of the relevant security sector and the whole system of its provision. For instance, Sustainable Development Strategy «Ukraine - 2020», which defines a security vector as one of the main directions of the country's movement, provides the implementation of 62 reforms and state development programs. The aim of the legislative reforms is to ensure the security of the individual, society and the state,

${ }^{19}$ Дацюк А., Садовський В., Полтораков О., Марутян Р. Аналіз державної політики у сфері національної безпеки і оборони України : виконано групою експертів за підтримки Реанімаційного пакету реформ. Київ, 2015. С. 21-41.

${ }^{20}$ Про Стратегію сталого розвитку «Україна - 2020»: Указ Президента України від 12.01.2015 № 5/2015. URL: http://zakon2.rada.gov.ua/laws/show/5/2015.

21 Про Стратегію національної безпеки України: Указ Президента України від 26.05.2015 № 287/2015. URL: http://www.rnbo.gov.ua/documents/396.html. 
the implementation of European standards of living in the country, the creation of an effective security and defense sector, and Ukraine's taking the leading position in the world. Also, these documents provide specific mechanisms for reforming, this fact differentiates them substantially from all other documents adopted during Ukraine's independence to regulate this sphere.

Given that the effectiveness of public policy in the field of national security «is largely determined by the state of development of national security theory and the level of implementation and application of appropriate methods, techniques, models, mechanisms, principles, etc. in the process of practical solution of actual problems of state formation» ${ }^{22}$, it should be noted that in theory it has been fully substantiated, but the use and implementation of certain tools and mechanisms to produce the expected effect requires updating and substantially improving the legal framework and coordinated actions of government entities in all spheres of life of the country, development and implementation of technologies for reducing conflict and destabilizing factors.

\section{CONCLUSIONS}

Substantial changes in the field of international and national security are currently underway, and are mainly related to the intensification of globalization processes in the eco- and social system. The nature and tendencies of the modern globalization process are determined, on the one hand, by the objective component, which contains the causes of the positive, regular manifestations of globalization, and, on the other, the subjective component, in which the causes of its negative manifestations are laid. In this context, special attention is paid to the new system of international relations, which becomes the main criterion for the formation of a large number of threats of various nature for international and national security.

The main priority and strategic task of the state policy of Ukraine in the field of national security is to ensure internal political processes: restoration of the territorial integrity of Ukraine at the borders of 1991; the return of Ukrainian sovereignty; unity of the country and consolidation of Ukrainians as a modern political nation. At the heart of Ukraine's national security is a set of ideas about human and citizen security, achieved through the creation of political, economic, social, environmental and other conditions that, in their unity, will provide them with decent living conditions, self-fulfillment, wellbeing and freedom.

An important condition for the realization of priority and strategic tasks in this field is the growth of Ukraine's international prestige, strengthening of its subjectivity on the world arena, active participation in the processes of globalization, in the formation of a new system of

22 Власюк О. С. Національна безпека України: еволюція проблем внутрішньої політики : вибр. наук. праці. Київ : НІСД, 2016. С. 12. 
international relations. Ukraine's EU membership and NATO membership are an irreversible guarantee of Ukraine's security. In general, Ukraine maintains peaceful and mutually beneficial cooperation with the members of the international community in accordance with generally recognized norms and principles of international law, adheres to the basic principles of relations between states based on their international obligations, first of all, the UN Charter, as well as the provisions of the Helsinki Final Act, European Security Charter and other instruments whose main purpose is to create a single international security system.

However, in today's rapidly changing international security environment, driven by global processes of restructuring the world, Ukraine needs to take many practical steps to strengthen its global role on the international arena, take a leading position in the world hierarchy, and ultimately ensure its own national security.

\section{SUMMARY}

The essential characteristics of the concept of «international security» and «national security» have been considered. The real and potential threats to international and national security have been identified and analyzed. It is stated that the considered threats of the international and national levels are interdependent and determining factor for both security spheres, given that they continuously exert mutual influence on each other. At the same time, the main threats to the national security of Ukraine are of domestic origin, which are largely due to its uncertainty in carrying out constructive actions on the regional and international arena, as well as inadequate response to new world realities. The main priorities and strategic tasks of Ukraine's national security policy have been analyzed. Emphasis is placed on the institutional and legal support of the activity of our state in this field. The article emphasizes that, tasing into account certain positive developments in the national security of Ukraine, the development and implementation of political and legal and security strategies, certain tools and mechanisms to obtain the expected effect in the field of counteracting threats as well as the continuous improvement of its security system are still relevant today. 


\section{REFERENCES}

1. Концептуальні засади розвитку системи забезпечення національної безпеки України : аналіт. доп. / О. О. Резнікова та ін. Київ : НІСД, 2015. $58 \mathrm{c}$.

2. Власюк О. С., Пирожков С. І., Бєлов О. Ф. Концептуальні підходи до формування системи національної безпеки України / О. С. Власюк. Національна безпека Украӥни: еволюція проблем внутрімньої політики : вибр. наук. праці. Київ : НІСД, 2016. С. 23-50.

3. Власюк О. С., Кононенко С. В. Національна безпека України: стратегічні виклики, національні інтереси та пріоритети забезпечення / О. С. Власюк. Національна безпека України: еволющія проблем внутрішньої політики: вибр. наук. праці. Київ: НІСД, 2016. C. 15-22.

4. Телешун С. О. Глобальні виклики та ризики, які загрожують світу у 2010-2015 рр.: місце і роль ООН у цих процесах. Актуальні проблеми міжнародних відносин. 2011. Вип. 96. Ч. І. С. 9-10.

5. Білас I. Г. ООН та сучасні виклики і загрози міжнародній спільноті та безпеці в умовах глобалізації. Актуальні проблеми міжнародних відносин. 2011. Вип. 96. Ч. І. С. 34-39.

6. Чекаленко Л. Д. Національна безпека України: система реалізації. Зовнішні справи. 2016. № 11. С. 17-19.

7. Аналітична доповідь до Щорічного Послання Президента України до Верховної Ради України «Про внутрішне і зовнішне становище України в 2016 р.». Київ : НІСД, 2016. 688 с.

8. Конституція України : офіц. текст. Відомості Верховної Ради Украӥни. 2019. № 9. Ст. 50.

9. Тімкін I. Система національної безпеки України: стан та перспективи розвитку. Нова парадигма. Київ: Вид-во НПУ ім. М. П. Драгоманова, 2015. Вип. 128. С. 162-170.

10. Про Стратегію національної безпеки України : Указ Президента України від 26.05.2015 № 287/2015. URL: http://www.rnbo.gov.ua/ documents/396.html.

11. Про національну безпеку України : Закон України від 21.06.2018 № 2469-VIII. Відомості Верховної Ради. 2018. № 31. Ст. 241.

12. Про засади внутрішньої і зовнішньої політики: Закон України від 01.07.2010 № 2411-VI. Дата оновлення: 08.07.2018. URL: http://zakon2.rada.gov.ua/laws/show/2411-17 (дата звернення: 13.09.2019).

13. Про рішення Ради національної безпеки і оборони України від 4 березня 2016 року «Про Концепцію розвитку сектору безпеки i оборони України»: Указ Президента України від 14.03.2016 № 92/2016. URL: http://www.president.gov.ua/documents/922016-19832. 
14. Дацюк А., Садовський В., Полтораков О., Марутян Р. Аналіз державної політики у сфері національної безпеки і оборони України : виконано групою експертів за підтримки Реанімаційного пакету реформ. Київ, 2015. $41 \mathrm{c.}$

15. Про Стратегію сталого розвитку «Україна - 2020»: Указ Президента України від 12.01.2015 № 5/2015. URL: http://zakon2.rada.gov.ua/ laws/show/5/2015.

16. Власюк О. С. Національна безпека України: еволюція проблем внутрішньої політики : вибр. наук. праці. Київ : НІСД, 2016. 528 с.

Information about the author: Hedikova N. P.,

$\mathrm{PhD}$ in Political Sciences, Professor, Professor at the Department of Political Science and Law, State Institution «South Ukrainian National Pedagogical University named after K. D. Ushynsky» 26, Staroportofrankivska str., Odesa, 65020, Ukraine 


\section{POST-COMMUNIST TRANSFORMATION AFTER 2004: CASES OF POLAND AND HUNGARY}

\section{Koval I., Brusylovska O.}

\section{INTRODUCTION}

The last years have showed that post-communist countries, which generally completed transition from one system to another, face serious political, social and ethno-national problems. This confirms an idea, that Central Europe keeps originality in creation of democratic institutes. Despite the process of European integration, it continues to differ from the Western Europe. As Gallup stated from all regions of the world Central Europe is the most sceptical of the thesis that democracy is the best form of rule. Professor of Poznan University M. Zhulkovski notes pragmatism of his country approach: majority of Poles believe that democracy is useful only when it brings prosperity; much less they value the freedom associated with democracy. Even after 2004 up to 52\% of Poles tended to authoritarianism. Only $10 \%$ of the population participates in the civil society`s activities; this is the lowest index in Central Europe ${ }^{1}$.

Famous Polish sociologist A. Ryhard in his study of new phraseology of political life concluded that institutions do not arise from nothing; they are rooted in the culture. For Poland the roots of its democratic values remain quite weak. Ryhard even considers that maybe here, in Central Europe, a new model of democracy is emerging, which includes elements of populism, authoritarianism, and "democratic majority". He concluded that the "new institutional system was formed with the own logic of development, identity, structure, recreation ability and connection mechanism. As a rule, this system is reflected in term "post-communism". He means that the concept of "postcommunism" is not normative, but descriptive ${ }^{2}$.

The aim of the work is to reveal the special features of "postcommunist” countries after their accession to the European Union in 2004. The main method is case-study (Poland and Hungary).

${ }^{1}$ Брусиловская О. И. Теоретические основы исследования системной трансформации стран Центральной и Восточной Европы. E-gospodarka, e-spolechenstwo w Europie Srodkowej i Wschodniej, red. S. Partycki. T. 1. Lublin: KUL, 2009. S. 294.

${ }^{2}$ Рыхард А. Посткоммунизм: Институциональный порядок или хаос. Cистемные изменения и общественное сознание в странах Восточной Европы. М.: ИНИОН, 2008. С. 34. 


\section{The economic transformation of Poland and Hungary under the conditions of their membership in the $\mathbf{E U}$}

First of all, after the accession to the EU in May 2004 the governments of states - new members made the programs of subsequent reforms to increase the living standards of their citizens.

In Hungary the "Convergence programme for 2005-2008" was aimed at diminishing of charges and increase of incomes in the state budget. Its purpose was to create conditions for the balanced economic development. Foremost the deficit of state budget in 2009 was to be 3.2\% (in $2006-10 \%$ ) level acceptable to the EU. The programme implied unpopular measures, which temporally had to put the brakes on the economy growth to $2.2-2.6 \%$ in 2007-2008, but from 2009 to be returned to 4.1\%; the splash of inflation was also foreseen to $5.5 \%$ in 2007 against $3.6 \%$ in 2005 . The second programme "the New Hungary Development Plan" (2007-2011) was aimed at the reforming of industry and envisaged that in 2009 the economic indicators would correspond to the Maastricht requirements. The third program the "New Széchenyi Plan" (2011-2013) dealt with the distribution of money of the EU structural funds within the framework of 15 operative programs. A lump sum was 7000 billion of forints. 1721.5 billion of forints were assigned to the development of transport, 1600 billions of forints on social projects, including the development of healthcare, education, and increase in employment. The agriculture faced three foreground tasks - balanced development of plant growing and stock raising, effective application of climate conditions for the production of bioenergy ( 800 thousands of tons of bioethanol per year). Thus, it was planned to export $80 \%$ of bioethanol to other countries of the $\mathrm{EU}^{3}$.

But the reality in Hungary became complicated after statement of the Prime Minister Ferenc Gyurcsany concerning the economic inactivity of government during 2002-2006. The subsequent analysis of situation was complicated by an ever-higher state budget deficit - 4\% of GDP in 2006 and $8 \%$ in 2007. Society did not support the program of reforms because the last foresaw expansion of the taxation base, the pension system reform, diminishing the number of workers in a public sphere etc. However, the European Commission noted that the main threat to country would be a rejection of these reforms. The guidance of the EU warned that if Hungary had not executed its obligations till 2009, the issue of its withdrawal of structural funding of the EU would have been raised appear. Among the difficult commitments was clearing of 27 billion Euros foreign debts. Thus, the currency backlogs of Hungary by the end of 2008 were 17 billion Euros. However, the world economic crisis made its amendments. Although Hungary

${ }^{3}$ Брусиловская О. И. Социально-экономические трансформации в посткоммунистических странах Европы: пример Венгрии. Spoleczenstwo sieci. Gospodarka sieciowa w Europie Srodkowej i Wschodniej, red. S. Partycki. Lublin: KUL, 2011. S. 183. 
suffered less than other Baltic or Balkan countries, the IMF, the World bank and the EU co-ordinated the 25.1 billion dollars package of financial help to Hungary in 2009 (the EU allocated 8 billion dollars) ${ }^{4}$.

Passing to description of basic economic indicators in these countries, it should be noted that they remained sufficiently ambivalent. During the first three years of Poland`s membership in the EU the economy grew at an annual average of $4.2 \%$. With this index Poland occupied the eighth place among 25 countries of the EU. The GDP growth rates were $5.3 \%$ in 2004 and $3.4 \%$ in 2005 . However, despite the fact that the GDP per capita grew from $40 \%$ - a middle index for the EU to $46 \%$ in 2005 , analysts considered such growth rates as too slow: the majority of other countries-newcomers of the EU were ahead of Poland. In 2007 the economy growth was $6.7 \%$, that was unexpected even for the government (the plan envisaged $4.6 \%$ ). The rates of Hungary`s GDP growth were at average annual of 3-5\%. At the same time state debt of Hungary exceeded $60 \%{ }^{5}$.

The locomotive of the economic growth in Central Europe was production, especially industrial. It distinguished the new members of the EU from the old ones, where a leading role was played by the service sector. But such situation could not last for a long time: in 10-20 years the regional countries would follow the course of other developed European states. In 2008 analysts noted that the strong sides of Hungarian economy were the innovative activity, efficiency of service sector, considerable external economic impact.

The structure of economy of the countries of Central Europe generally meets the standards of the EU. Therefore, in Hungary services constitute $68.7 \%$, industry $-27.4 \%$, agriculture $-5 \%$. In Poland service sector is $59.8 \%$, industry $-20.8 \%$, building $-5.7 \%$. An important task is the strengthening of export constituent of production 6 .

In Poland 50\% of enterprises are orientated on export; foremost it is the motor industry (during 2003-2005 it grew twice after "Fiat", “Opel", "Volkswagen", "Toyota" came to Poland), the machinery, production of telecommunication equipment (including television sets of technological lines of "Toshiba" and "Phillips"), ware production from plastic and rubbers was modernised with participation of foreign capital. The export expansion of the agricultural products contributed to the markets of the EU; a difference

\footnotetext{
${ }^{4}$ Брусиловская О. И. Социально-экономические трансформации в посткоммунистических странах Европы: пример Венгрии. Spoleczenstwo sieci. Gospodarka sieciowa w Europie Srodkowej i Wschodniej, red. S. Partycki. Lublin: KUL, 2011. S. 184.

${ }^{5}$ Брусиловська О. I. Економічна трансформація країн Східної Свропи в умовах членства в Європейському Союзі. Вісник ОНУ. Серія: Сочіологія. Політичні науки. 2008. Т. 13. Вип. 3. С. 179-186.

${ }^{6}$ Бальцерович Л. Как это было. Стабилизация и реформы в Польше в чрезвычайных и нормальных политических условиях. http://www.vestnik-evropy.ru/issues/as-it-wasstabilization-and-reform-in-poland-in-emergency-and-normal-political-conditions.html.
} 
in prices on these products resulted in the growth of competitiveness of the Polish commodities. In 2007 export gave Poland 101.1 billion Euros. Hungary increased export to West Germany, Austria, Italy, France, Great Britain, and to the EU newcomer countries. The structure of export was the following: $62 \%-$ electronics, telecommunication commodities, machines, transport vehicles, $29.8 \%$ - the commodities of chemical and pharmaceutical industry, metal and plastic wares, soft goods, $6.1 \%$ - food stuffs, drinks, tobacco. The $50 \%$ of import structure has constituted the "machinery and transport vehicles" what could be considered as a new positive line ${ }^{7}$.

However, the point-of-sale deficit of Hungary was 1 billion Euros in 2007. Balance of trade of Poland was positive with countries of the EU (foremost due to liberalisation of food stuffs trading), but the general balance remained negative due to trade with the EU`s non-member countries. It can be explained by the fact that Poland was forced to accept the European tariff regulations and they fell down on average from $8.9 \%$ to $4.1 \%$. Thus, import from developing countries (foremost from China) grew swiftly.

The situation changed for better with the improvement of Poland`s state budget. Profitable part of Poland`s budget was 156.3 billion PLN (2.7\% more than in 2003) in 2004. Expense part was 197.8 billion PLN; a budgetary deficit was 41.5 billion PLN (4.7\% GDP). Consequently, the index of correlation of national debt and GDP was 50.5\%, that held back within $55 \%$ "threshold of safety", which was foreseen by the Law on State Finances. From May 2004, in Poland a tendency was obviously to reach the unprecedented strengthening of zloty. Zloty average annual rate was 3.6 to dollar and 4.5 - to euro ${ }^{8}$.

The Warsaw exchange (WSE) was rated $13^{\text {th }}$ among the biggest exchanges stocks of Europe, and with the number of its new participants, which accessed it during 2004, took the second place after London. The index of capitalisation of WSE reached 70.5 billion Euros. The main participants of WSE were the Austrian bank of "Creditanstalt AG", Polish banks (PKO of VR and PKO SA), "Polish telecommunications", Hungarian business conglomerate MOL.

The income from direct foreign investment in Poland grew during its first year in the EU, but this dynamic slowed later. The relative index of the combined foreign investment Poland was ranked fifth from seven postcommunist newcomer countries-to the EU in 2007, only Slovenia and Romania were below. The leading investors to Poland`s economy were countries of the EU with 83\% of FDI in 2005. Leaders were the Netherlands, Germany and France, which provided almost $61 \%$ of combined income of FDI

${ }^{7}$ The World Bank. http://data.worldbank.org/indicator/NY.GDP.MKTP.CD?locations=HU.

${ }^{8}$ Djankov S., Hauck O. Economic and Political Freedoms Diverge in Eastern Europe. https://piie.com/system/files/documents/wp16-10.pdf. 
to Poland. Also, Polish foreign investment grew - 636 billion Euro in 2004, 2493 billion Euro in $2005^{9}$.

In general, social problems in these countries were very similar. For all countries of Central Europe failings are characteristic in functioning of society - health protection, labour. Activity of trade unions is generally assessed as unsatisfactory. Rather new phenomenon, which was caused by the accession to the EU, was the increase in labour mobility. External mobility concentrated in direction of the EU`s three countries which opened their labour-markets Great Britain, Ireland, and Sweden. In 2004 near 250000 Poles were abroad at least two months (20\% more than in 2003) ${ }^{10}$. The inflow of foreign workers was not able to replace fully: the lack of qualified personnel marked in a few sectors, especially in healthcare. Consequently, Poland, as well as most of the EU`s new members started to consider the idea of softening of the immigration policy in relation to the EU`s non-member countries.

From the beginning of transformation, the rate of Polish GDP increased 5 fold. In 2005 it exceeded 303 billion dollars; in 2006 - 320 billion. As the result Poland found itself ranked twenty first among the world countries and eleventh in Europe in terms of GDP. GDP per capita in 2007 reached 7.1 thousand Euros. It allowed Poland to raise the level of average salary to 1100 dollars ${ }^{11}$.

Opinion polls showed the growth of positive assessment of the EU membership, which analysts didn`t expect. In 2006, 54\% of the Poles answered that it had brought a country more benefits than losses (the index was $39 \%$ in 2004, and $46 \%$ in 2005). The Poles recognised as the biggest benefit the possibility to work legally in other country-members of the EU, opened borders, support of agriculture, and access to the EU funds ${ }^{12}$.

However, with the EU membership not all issues acquired a positive dynamic. The main threat to the economic growth was instability of the energy market. All European countries have depended on Russian gas. The socialist government of Hungary signed an agreement with the RF on the construction of the Russian gas pipeline "Blue Stream". But according to the opinion of opposition it didn't comply with interests of country and the EU, as only strengthened dependence of Europe from Russia.

${ }^{9}$ Цифровые дивиденды. Доклад о мировом развитии. http://documents.worldbank. org/curated/en/224721467988878739/pdf.

10 Экономический бюллетень о странах с переходной экономикой. Трансформация. http://siteresources.worldbank.org/INTDECBEYT.

${ }_{11}$ Куликова Н. В. Прямые иностранные инвестиции как основа модернизации экономики: случай Центрально-Восточной Европы. www.imepi-eurasia.ru/baner/kulikova_ modernization.doc.

12 Лыкошина Л. Системные изменения в Польше в оценках общества и элиты. Системные изменения и общественное сознание в странах Восточной Европь. М.: ИНИОН, 2008. С. 43. 
The second issue is closely related to the aim of transformation. Achieving the goal carried not only new possibilities, but also threats. The fate of Central Europe became considerably more closely associated with the fate of the most developed countries of the world. It has a negative influence in terms of the world economic crises: it hit countries the more they get computer-integrated in the world economy. At the same time some leverage that were necessary for prevention of negative consequences of crises moved from national governments to the EU`s supranational structures.

Among other problems were: moderate increase of retail price, inflation, unemployment, and growth of external debt. But quite unforeseeable developments were related to the beginning of the world economic crisis in the end of 2008.

One of distinguishing features of crises in Central Europe was the delay of its negative consequences in comparison with more developed countries of the EU. Only in 2009 Central-European societies followed the world tendencies. At first problems were not in financial but in a public sphere: unemployment began to grow swiftly (7.9\% in the EU and to $8.5 \%$ in the Euro area) ${ }^{13}$. Then crisis hit motor industry, ship industry, metallurgy, and house building. There were national currency swings, but countries which hadn`t adopted the euro (Poland and Hungary) suffered less.

\section{Peculiarities of political transformation of Hungary and Poland}

Hungary can be considered as the most typical example of influence of EU's accession on the political transformation. Until 2004 Hungary implemented $99 \%$ of all regulatory resolutions enacted by the EU. Due to this fact Hungary's first year as an EU's member passed by almost unnoticed: there were no substantial disturbances or sudden changes.

The party consolidation led to their decrease from 200 to 70 parties at the beginning of the XXI century. Attempts to create new parties haven't had any success. Hungary succeeded among all post-communist states on its way to the establishment of the two-party system: both the Hungarian Socialist Party (MSZP) and the Union of Young Democrats - the Hungarian Civic Alliance (Fidesz) received approximately $90 \%$ of the votes.

However, citizens` expectations associated with the EU accession did not come true: it became evident that sole membership in the EU would not solve problems on its own; as it had been before, everything depended on the Hungarians themselves. The only raised question was whether the Hungarian elites were ready to deal with new difficult tasks associated with the

${ }^{13}$ Lomachynska I.A., Manchenko K.I. Influence of direct foreign investment on development of economics of Visegrad group countries: conclusions for Ukraine. National Economic Development and Modernization: experience of Poland and prospects for Ukraine. Riga: Baltija Publishing, 2017. P. 75. 
functioning of the state within the framework of the existing system with all its advantages and disadvantages. Domestic policy continued to develop under more strict conditions of confrontation between the empowered liberalsocialist coalition and the centre-right opposition, than it was noted in the neighbouring countries. In fall 2004 the EU's leaders even officially expressed their concern for "the deep division in the Hungarian society" 14 .

It became evident that it had been impossible to overcome this division during the government crisis of 2004. It was provoked by the initiatives of Prime-Minister Peter Medgyessy to introduce a system of direct elections of the Prime-Minister, to reduce the number of parliamentary deputies, and to provide a national list of candidates to the European Parliament. These initiatives led to a split between the PM and the MSZP leaders. The party members' discontent was intensified by the defeat of the MSZP in the European Parliamentary election in summer 2004, when the socialists received only 9 mandates, whereas the HCA got 12 . The movement for the renovation of the MSZP, headed by young functionaries was established. The movement became officially called "The Left Initiative", but unofficially it was called "the motor mechanics movement", because its leaders Istvan Hiller and Ferenc Gyurcsany in their program statement compared the Hungarian Socialist Party to an automobile in need to be repaired. At this point the leader of the MSZP and the Minister of Foreign Affairs Laszlo Kovac unexpectedly resigned and took the position of EU's Commissioner for Taxation. His resignation became the starting point for the change of the whole Old Guard of the party. The crisis ended with the announcement of Medgyessy of a rotation. However, the leaders of the Alliance of Free Democrats - The Hungarian Liberal Party (SZDSZ) objected strongly to the PM's proposition and presented a vote of no confidence. Unexpectedly for Medgyessy, the MSZP presidium agreed upon his dismissal from office; on August $25^{\text {th }}$ the extraordinary MSZP congress confirmed Ferenc Gyurcsany as the new PM. In September 2004 Gyurcsany formed a government. He set as his first goal the significant reduction of party apparatus and decrease in its maintenance expenses. However, in most aspects he followed Medgyessy, whose policy was mainly aimed at the improvement of the economy and was influenced by the EU and international financial organisations ${ }^{15}$.

The beginning of 2006 in Hungary passed under the slogans of a preelection race. The coalition partner of socialists, SZDSZ headed by Gabor Kuncz, put forward a number of conditions for the continuation of partnership

${ }^{14}$ Net International Investment Position Cohesion Policy and Hungary. http://ec.europa.eu/ regional_policy/sources/information/cohesion-policy-achievement-and-future-investment/factsheet/ hungary_en.pdf.

${ }^{15}$ Брусиловська О. І. Політична трансформація Угорщини в умовах членства в Свропейському Союзі. Вісник ОНУ. Серія: Соціологія і політичні науки. 2009. Т. 14. Вип. 2. С. 104. 
in the forthcoming elections. The demand for Hungary's healthcare system reform was among them. Fidesz, the leading opposition party headed by Viktor Orban, broadened the basis of its electorate due to the signing of a partnership agreement with the Union of Hungarian trade-unions in March. The program principles of Fidesz have a populist nature. The incapability of the right-wing parties to unite themselves reduced their chances to win; analytics, for example a well-known American political scientist Valerie Bunce places the main fault on Viktor Orban, known for his peremptory attitude and authoritarian manner of leadership ${ }^{16}$.

As a result of both rounds the MSZP received 190 mandates, the Fidesz together with the KDNP - 164, SZDSZ - 20, the HDF - 11. The government was again formed by the MSZP together with SZDSZ; thereto the leading block even improved its figures (in 2002 it received 198 mandates). Ferenc Gyurcsany (MSZP) remained the Prime Minister of Hungary. His speech during the closing session of the parliament fraction of MSZP on May $26^{\text {th }}$ 2006 became the prerequisite of Hungary's greatest political crisis of the whole post-communist period. Emphasising the necessity of carrying out the Convergence program adopted in December 2005, which undoubtedly demanded significant contributions from the population and managing subjects, Gyurcsany said: "For the passed one and a half - two years we lied about the state's economic situation....and we haven't done anything about it in these four years”" ${ }^{\prime 1}$. On September $8^{\text {th }} 2006$ this information reached the central press. That was the day the President of Hungary Laszlo Solyom made an announcement that the PM's statements had led to a moral crisis within the country. Ex-president Ferenc Madl (2000-2005) called upon Gyurcsany in his open letter to resign.

On the night from $18^{\text {th }}$ to $19^{\text {th }}$ of September in Budapest, participants of the two thousand people's anti-governmental demonstration surrounded the Hungary's state television building. They tried to get to the TV-centre and read out the demands of the Memorandum on the resignation of Gyurcsany's government. Despite the police force boundaries, several dozens of protesters broke the glass doors and windows of the first floor and broke into the TV-centre, bringing to it significant damage. Other participants on the square threw stones at the policemen and set fire to the cars. Water-cannons and tear gas were used against the protesters. The number of injured reached 159, and 114 of them were policemen ${ }^{18}$.

16 Брусиловская О. И. Системная трансформация посткоммунистических стран Центральной и Восточной Европы: российские и украинские исследования в XXI ст. Środkowoeuropejskie Studia Polityczne. 2018. N 4. P. 114. DOI 10.14746/ssp.2018.4.6.

17 Ткач Д. Будапешт: гаряча осінь 2006 року. Політика і час. 2006. № 11. С. 28.

${ }^{18}$ Ibid. C. 29. 
At the end of September, the situation somewhat stabilized: the opposition constantly organised meetings on Kossuth square near the State Parliament, demanding the government's resignation. All these events provide evidence that the political crisis in Hungary wasn't accidental.

First of all, the population's protests were not provoked to a large extent by the lies of the PM, but by the dissatisfaction with the economic situation and fear of its further deterioration. The worst situation was in the healthcare sphere, which lacked financial support and medical personnel. The financing of education and science decreased rapidly. The state declined the system of grants according to "The Széchenyi Plan" which provided an essential support to Hungarian researchers and professors. Similar tendencies could be found in the majority of public segment.

Secondly, Gyurcsany's speech became an excuse for confrontation between those in power and the opposition, which had been brewing for years. Viktor Orban used the discloser of economic performance of the state to accuse his opponents with incompetence, incapability to solve the urgent problems of the state, the non-transparency of the steps taken by the government in the socially susceptible spheres. Generally, the confrontation in Hungary had a tangibly personal character: Orban versus Gyurcsany. Political tactics of Orban brought noticeable results: during the local-government elections, which took place in October 2006, Fidesz, the KDNP, and the HDF won in 17 out of 19 regions. Orban called this event a historic failure of the socialists. And really very soon (from 2010 till today) he has strongly held power in his hands.

The European countries' reaction to Hungarian events was vague: socialists supported Gyurcsany, the right-wing parties - Orban. The official position of the EU on this was more calculated: the protests were thought of as events, provoked by the realisation of economic reform, which was actually aimed at overcoming the crisis in the economy. Thus, the least that Hungary needed was a change of government. It is interesting that Orban in 2006 also hadn't shown any signs of readiness to take on the pull-out of the country. He called upon not the early election, but the dismissal of Gyurcsany and the creation of a so-called 'professional government' out of members from all parties. Gyurcsany's anti-crisis reforms also had an impact on the problem of sharing power between bodies of authority. In two years, the number staff members of the administration were cut down by $30 \%$. A positive result of staff reduction was the cut in expenditure of the national budget, which at the same time allowed the PM to concentrate more power in his hands, first of all for account of power of other ministers. It was used by Orban later.

During the 2007 the administration managed to carry out reforms in several important spheres - the system of medical service, education, and public transport - with the purpose of minimising service expenditures, 
distributing to citizens through these systems. But the profits of the population decreased, which provoked an escalation of tensions within the Hungarian society and rise of the opposition's popularity. The opposition changed its campaign methods from forceful to constitutional, for example put forth an initiative to carry out a nationwide referendum on the social reform of the administration.

Thus, Gyurcsany was forced to implement reforms, unpopular with at least two thirds of the population, and upon their completion was bound to lose his post as PM and head of the party, because part of the socialists did not agree with the tough social policy of the government. After this historical crisis Hungary slowly starts to go down to modern populism and a sort of 'non-democracy' ('authoritarianism' of Orban).

In Poland the start of the new century was noted by the foundation of new political parties based on the background of disappointment in old leaders - the Democratic Left Alliance (SLD) and the Solidarity Electoral Action (AWS). In 2001 the "Civic Platform" (PO) was first registered. Andrzej Olechowski, Maciej Płażyński, and Donald Tusk were its leaders. They positioned themselves as conservative-liberals. Demands for the reduction of positions in the Sejm, passing of parliamentary election by majority system, implementation of direct elections of governors and majors, increase of expenditure in support of local self-government and educational system reform were among the main claims.

2005 in Poland passed under the sign of elections that we can call today historical. This campaign had very peculiar characteristics, determined by the simultaneous parliamentary and presidential elections, the results of which none of the analytics were able to predict.

The left-wing was headed by the Democratic Left Alliance (Włodzimierz Cimoszewicz), the right - by the "Civic Platform" (PO) and "Law and Justice" (PiS) headed by the Kaczyński brothers: Lech and Jarosław. However, in September 2005 (on the eve of elections), Cimoszewicz suddenly refused to participate in the elections campaign, calling it "too dirty". A unique situation had arisen when the right parties were forced to compete against one another which led to exaggeration of arguments among them during the actual campaign.

"Law and Justice" became the winner (33.8\%), and this victory created its very successful advertising campaign, emphasising traditional values, religious, national and historic roots in contrast to the ideas of European integration: "The integration has occurred, but most of the problems remain" ${ }^{19}$. Thus, PiS simply played off against the fears of their fellow

19 Лыкошина Л.С. «Мы» и «они». Проблема польской идентичности в контексте отношения к другим народам. Страны Восточной Европы в поисках новой идентичности. М.: ИНИОН, 2006. С. 67. 
countrymen before the future, modernisation, and new living conditions in united Europe. The government was formed by the coalition of "Law and Justice” (155 mandates), "Self-Defence of the Republic of Poland” headed by Andrzej Lepper (11.4\%, 56 mandates), catholic "League of Polish Families" (8\%, 34 mandates). Kazimierz Marcinkiewicz became Prime Minister of Poland. The PO received $29 \%$ of the vote and crossed over to the other side ${ }^{20}$.

On October $23^{\text {rd }}, 2005$, Lech Kaczyński won the second round of elections (54\%). Tusk received $46 \%$ of the votes, which was in itself a rather good result. Analytics believe that support of the Catholic Church and Andrzej Lepper, who "controlled" the larger portion of the Polish villagers' votes, helped Kaczyński very much. The President gave to understand very quickly, that he couldn't see eye to eye with the Prime Minister, who tried to take actions by himself, thus, in June 2006 Marcinkiewicz gave up his post to Lech Kaczyński's brother - Jaroslaw ${ }^{21}$.

In the time of the Kaczyński relations with the EU had become worse first of all because of accusations of the FRG in revanchism and demands from Berlin to pay all the damages, obtained by Poland after World War II.

The Kaczyński brothers announced a crusade against evil and began to reform all the social-political spheres, based on the following principles: 1) a centralized "active and strong state"; 2) a struggle against "the system" (gangsters, secret agencies, corrupted officials, malicious entrepreneurs); 3) "revolutionary change of elites"; 4) "Catholicism as a national obligation"; 5) mass media control; 6) "management through chaos". The pro-Catholic position of the Kaczyński, especially, was brightly manifested. It seemed that the times of theocracy, which had formed at the beginning of the 1990s, had once again come to Poland. After 2005 there was a great deal of anxiety in the domestic life of the country. The Kaczyński brothers did everything possible to build a fire of mutual hate, having adopted several laws on disclosure of personal files. In November 2007 PM Jaroslaw Kaczyński announced an administration clear-out from left-wing officials, accusing them with corruption ${ }^{22}$.

This became the last straw: a political crisis occurred and pre-term parliamentary elections took place on $21^{\text {st }}$ October 2007. Social surveys on the eve of elections indicated that the Poles considered the biggest threats to be

${ }^{20}$ Haliżak E. Bezpieczeństwo narodowe Polski: geopolityczne i geoekonomiczne uwarunkowania. Toruń: Adam Marszałek, 2007. S. 43.

21 Брусиловська О. I. Особливості політичного розвитку Польщі на початку XXI століття: основні тенденції, проблеми, досягнення. Ужсгородські польські наукові читання: історія, культура, політика, право, ред. М. Лендьел, М. Палінчак. Ужгород: Ліра, 2014. C. 102.

${ }^{22}$ Brusylovska O. Post-communist identities and their transformations: The cases of Poland and Romania. Balkan and Baltic States in United Europe. Histories, Religions, and Cultures II, eds. E. Anastasova, S. Toncheva. Sofia: Paradigma Publishing House, 2018. P. 59. 
the growth of corruption (79\%) and crime (41\%). Thus, even though J. Kaczyński declared fighting these occurrences, their level only increased. Therefore, the elections turned out to be a sort of referendum on one question: "for" or "against" J. Kaczyński ${ }^{23}$.

The elections revealed Poland's geographical division - the South and Eastern regions voted for PiS, and the West - for PO; and social division - the citizens of large cities, the younger generation and intelligence voted for PO.

PO received the victory of $41.5 \%$ of the vote, leading by $10 \%$. Therefore, PO and the Polish People's Party (8.9\%) headed by Waldemar Pawlak formed a coalition government. In November Donald Tusk became the new PM, Waldemar Pawlak took the post of Vice-PM and Minister of Economy, Radosław Sikorski became the Minister of Foreign Affairs ${ }^{24}$.

The new government made several attempts to correct the mistakes of its predecessors, but stumbled upon the uncompromising resistance of the President every time. The confrontation between the President and the PM defined the colours of Poland's political life for years. The confrontation passed under the motto of revision of the President's and Prime Minister's responsibilities, but it did not result in a broader discussion over more important issues.

Tusk tried to draft a new legislation, which would limit the President's authority. According to the legislation the PM was supposed to be the one representing Poland at EU summits. The President's participation was possible only in special cases and with the approval of the government. However, later on Tusk personally refused to put forward any of his party's bills, which could undermine authority. It seemed that maintaining political stability under any circumstances became his motto. Thus, Tusk tried to shelve all discussions and disputable questions.

To nowadays careful behaviour of Donald Tusk as PM benefited him with first place in the ratings of Polish politicians despite he was absent in Poland (as a President of the European Council from 2014 to 2019). Today Poland waits for his return on the national political arena. President Lech Kaczyński put an emphasis on ideological problems, not economic, and attempts to strengthen the authority of the Roman Catholic Church till his tragic death in 2010. But his brother remains important figure in Polish political life. So, from 2005 till today PiS and PO stays the main opponents and the most influential parties in Poland.

${ }^{23}$ Лыкошина Л.С. «Мы» и «они». Проблема польской идентичности в контексте отношения к другим народам. Страны Восточной Европы в поисках новой идентичности. М.: ИНИОН, 2006. С. 66.

${ }^{24}$ Польские парламентские выборы 2007 года. Системные изменения и общественное сознание в странах Восточной Европы. М.: ИНИОН, 2008. С. 38. 


\section{CONCLUSIONS}

Summarising experience of these two Central-European countries, it is possible to select a few positive tendencies. Achievements of countries members of the EU after 2004 were to a great extent associated with character of institutional and normative legal reforms which were conducted before the accession to the EU. Adaptation to the legislation of the EU allowed them to conduct deep reforms in a sphere adjusting of economy, which was instrumental in the improvement of business climate and economy growing. At the same time the lack of legislation, which remained at the moment of accession and unsatisfactory activity of the government became main reasons of the negative phenomena in the economic development of countries. Another issue, related to the economic crisis, is a problem of economic administrative ethics. To the surprise for societies, the apex of managers continued to plunder public money, allocated to the overcoming of crisis. Consequently, the process of exit from a crisis appeared in direct dependence on maintaining of moral of every separate country. So, it should be remembered when making the analysis of economic transformation is its direct dependence on the political terms of holding of the reforms, knowledge of government, ability to co-ordinate the interests with the European ones.

In political sphere it should be mentioned several important trends. Firstly, increased political competition has led to the partial loss of clearly defined ideological affiliation by political parties, called a certain "deideologization". Today a large number of parties of populist nature have appeared which affects the behaviour of key political players: they have to adapt to the situation, even if it is necessary to move away from its ideological line. The main risk concerned with this situation is that the electoral programs that are populist in nature can not serve as the basis for a clear political course. Classical scheme typical for Western Europe (right, centrists, left), has not evolved in Central Europe. Secondly, elections of recent years have shown that the focus of the society is primarily on social issues, economic issues, and domestic development. Thirdly, accession to the EU requires to understanding of the changes in the political system, which have taken place and will take place. Policy space for political parties has grown considerably; this cannot be ignored even by euro-sceptics claim. They are forced to modify their programs, to abandon passivity, to participate in elections to the European Parliament and to defend their national interests at this new level. Fourthly, there was a change of the general mood of voters: from euphoria of 1990s, they moved to accept the election as a formality, which has limited the population's real impact on political process. In general, the political activity of the population remains low: only $2 \%$ of respondents in Poland and Hungary are members of political parties. Parties have elitist, apical character. In practice, in the activities of political parties their own interests dominated 
rather than the interests of citizens. Fifthly, both Poland and Hungary are more or less euro-pessimistic, affecting the way of transformational reforms and become less stable and predictable. Today ideas and energy of political elites, who started the transformation, exhausted, these countries entered more complex stage of political development, the stage of destabilization. Only the issue of its timing and form remains open.

\section{SUMMARY}

The aim of the work is to reveal the special features of "postcommunist" countries after their accession to the European Union in 2004. The main method is case-study (Poland and Hungary). After the accession to the EU in May 2004 the governments of the new members states developed programmes of subsequent reforms to increase their citizens`standard of living. The locomotive of the Central Europe`s economic growth was production, especially industrial. It distinguished the new members of the EU from the old ones, where a leading role was played by the service sector. But such situation could not last for a long time: in 10-20 years the regional countries would follow the course of other developed European states. The main threat to the economic growth was instability of the energy market. 2005-2006 became the prerequisite for Hungary's and Poland's great political crisis. After this historical crisis Hungary has slowly started to slide to modern populism and a type of "non-democracy" of Victor Orban. Similarly, to this struggle, in Poland from 2005 till today PiS and PO have stayed the main opponents and the most influential parties in Poland.

\section{REFERENCES}

1. Brusylovska O. Post-communist identities and their transformations: The cases of Poland and Romania. Balkan and Baltic States in United Europe. Histories, Religions, and Cultures II, eds. E. Anastasova, S. Toncheva. Sofia: Paradigma Publishing House, 2018. P. 56-65.

2. Djankov S., Hauck O. Economic and Political Freedoms Diverge in Eastern Europe. https://piie.com/system/files/documents/wp16-10.pdf.

3. Haliżak E. Bezpieczeństwo narodowe Polski: geopolityczne i geoekonomiczne uwarunkowania. Toruń: Adam Marszałek, 2007. 68 s.

4. Lomachynska I. A., Manchenko K. I. Influence of direct foreign investment on development of economics of Visegrad group countries: conclusions for Ukraine. National Economic Development and Modernization: experience of Poland and prospects for Ukraine. Riga: Baltija Publishing, 2017. P. 74-86.

5. Net International Investment Position Cohesion Policy and Hungary. http://ec.europa.eu/regional_policy/sources/information/cohesionpolicy-achievement-and-future-investment/factsheet/hungary_en.pdf. 
6. The World Bank. http://data.worldbank.org/indicator/ NY.GDP.MKTP.CD?locations=HU.

7. Бальцерович Л. Как это было. Стабилизация и реформы в Польше в чрезвычайных и нормальных политических условиях. http://www.vestnik-evropy.ru/issues/as-it-was-stabilization-and-reformin-poland-in-emergency-and-normal-political-conditions.html.

8. Брусиловська О. I. Економічна трансформація країн Східної Свропи в умовах членства в Свропейському Союзі. Вісник ОНУ. Серія: Сочіологія. Політичні науки. 2008. Т. 13. Вип. 3. С. 179-186.

9. Брусиловская О. И. Теоретические основы исследования системной трансформации стран Центральной и Восточной Европы. E-gospodarka, e-spolechenstwo w Europie Srodkowej i Wschodniej, red. S. Partycki. T. 1. Lublin: KUL, 2009. S. 292-296.

10.Брусиловська O. I. Політична трансформація Угорщини в умовах членства в Свропейському Союзі. Вісник ОНУ. Серія: Соціологія і політичні науки. 2009. Т. 14. Вип. 2. С. 103-110.

11.Брусиловская О. И. Социально-экономические трансформации в посткоммунистических странах Европы: пример Венгрии. Spoleczenstwo sieci. Gospodarka sieciowa $w$ Europie Srodkowej i Wschodniej, red. S. Partycki. Lublin: KUL, 2011. S. 181-185.

12. Брусиловська О. I. Особливості політичного розвитку Польщі на початку XXI століття: основні тенденції, проблеми, досягнення. Ужгородські польські наукові читання: історія, культура, політика, право, ред. М. Лендьел, М. Палінчак. Ужгород: Ліра, 2014. C. 100-107.

13.Брусиловская О. И. Системная трансформация посткоммунистических стран Центральной и Восточной Европы: российские и украинские исследования в XXI ст. Środkowoeuropejskie Studia Polityczne. 2018. N 4. P. 113-134. DOI 10.14746/ssp.2018.4.6.

14. Куликова Н. В. Прямые иностранные инвестиции как основа модернизации экономики: случай Центрально-Восточной Европы. www.imepi-eurasia.ru/baner/kulikova_modernization.doc.

15. Лыкошина Л. С. «Мы» и «они». Проблема польской идентичности в контексте отношения к другим народам. Страны Восточной Европы в поисках новой идентичности. М.: ИНИОН, 2006. С. 63-70.

16. Лыкошина Л. Системные изменения в Польше в оценках общества и элиты. Системные изменения и общественное сознание в странах Восточной Европы. М.: ИНИОН, 2008. С. 41-48.

17.Польские парламентские выборы 2007 года. Системные изменения и общественное сознание в странах Восточной Европь. М.: ИНИОН, 2008. С. 38-40. 
18. Рыхард А. Посткоммунизм: Институциональный порядок или хаос. Системные изменения и общественное сознание в странах Восточной Европы. М.: ИНИОН, 2008. С. 33-37.

19.Ткач Д. Будапешт: гаряча осінь 2006 року. Політика $i$ час. 2006. № 11. С. $28-34$.

20.Цифровые дивиденды. Доклад о мировом развитии. http://documents.worldbank.org/curated/en/224721467988878739/pdf

21.Экономический бюллетень о странах с переходной ікономикой. Трансформация. http://siteresources.worldbank.org/INTDECBEYT.

Information about the author:

Koval I.,

Dr (Political Sciences), Professor, Rector, Odessa I. I. Mechnikov National University 2, Dvorianska str., Odesa, 65082, Ukraine

Brusylovska O., Dr (Political Sciences), Professor, Head of the International Relations Department, Odessa I. I. Mechnikov National University 2, Dvorianska str., Odesa, 65082, Ukraine 


\section{NECESSITY AND LIMITS OF STATE INTERVENTION TO THE ECONOMY OF MODERN COUNTRIES}

\section{Muzychenko G. V.}

\section{INTRODUCTION}

The financial crisis of 2008-2009 has demonstrated the lack of theoretical research on the state as a public goods and services producer and on the optimal scale of state intervention to the institutional structure of the national economic system as well. The ability of market relations subjects to adapt to new conditions of economic instability, the state's ability to form an effective mechanism to compensate for the global economic crises impact on national economic systems by evaluation the country's resource potential necessary for achievement of the set goals, taking into account available budget possibilities and emerging budget constraints depend on solving these fundamental theoretical problems directly.

The dominant scientific paradigm of the interpretation of the essence of the interaction of the state and the market, based on neoclassical approaches and views of other economical schools' representatives according to which the state is devoted to increase the level of market efficiency by eliminating its "failures», proved to be imperfect due to the inability to explain modern institutional transformations ${ }^{1}$.

The globalization processes' strengthening has substantially changed the understanding of the public finances essence and led to the evolution of theoretical approaches to their interpretation. The traditional public finance theory based on the welfare and public choice focuses on the formation of the revenue and expenditure part of the central (state) and local budgets, examines the mechanism of their interaction in the context of financing public goods and services. A new theory of public finance considers the interaction of the state and the market in the context of cooperation and competition between public and private market agents regarding the provision of public services and takes into account the need for concerted action of governments at the national and international levels to address global development challenges, especially in the face of aggravation of the crisis phenomena in the economy.

As A.G. Zeldner pointed: "We can endlessly argue about the state's place and role in the economy, but there is a period in the development of each

${ }^{1}$ Koliada, T. Forming of budgetary strategy of Ukraine: theory, methodology, practice. Irpin: University of State Fiscal Service of Ukraine, 2016. 396 p. 
country when only the activation of the role of the state and the clear longterm strategy development can provide a steady socio-economic growth» ${ }^{2}$.

Under conditions of globalization, when the economy goes beyond the bounds of the state, the problem of interdependence between the state and the economy becomes of particular importance for economic methodology. Economic determinism' followers associate this process with the dismantling of state institutions in general, with the self-liquidation of the state as such. Instead, A. S. Galchinsky believes that this problem is associated with a profound systemic reconstruction of state functions, which are due to the controversial process of becoming a post-industrial, global society ${ }^{3}$.

We are agree with Galchinsky's opinion that the modern global information economy, which operates on-line, is based on a fundamentally different basis. A new understanding of the need for a systemic separation of political power and economy is going to change the previous Keynesian and Neo-Keynesian approaches based on the state's functions expansion. It is about the limiting of state's economic function and developing new mechanisms for economy regulation, which will be formed within the economy itself.

The level of state interference in the country's economy is determined by the share of GDP redistributed through the budget. Today there is no consensus among scholars regarding the determination of the optimum budget size and its structure. The analysis of scientific sources shows that a significant part of the key issues in determining the optimal size of budget expenditures for a given country with all its internal and external factors remain unresolved. Therefore, every year during the process of Ukraine's fiscal policy main directions defining for the relevant year, scholars and experts discuss the main parameter of fiscal policy - the share of GDP redistribution through the consolidated budget.

\section{Theoretical aspects of state intervention to the economy}

After the declaration of independence and sovereignty of Ukraine as a state, the political power's division and formation is conducted in accordance with a democratic regime characterized by the following features: public sovereignty, political pluralism, consensual type of political culture, legal guarantees of political, civil and cultural freedoms. Democracy has its own influence on the economic system as reflected in the efforts of most democratic states to build a social model of the state.

2 Zeldner, A. State and market: strategy of development of economic relations. Announcer of Institute of economy of Russian Academy of Sciences, 2007. Vol. 3, p. 10.

${ }^{3}$ Гальчинський А. Вилікувати економіку можна тільки на ліберальних засадах. URL: http://www.dt.ua/2000/2020/68567/ (Accessed 15.09.2019). 
The transformation of our state's social structure in the 1990's sets an agenda a tusk for choosing a model of social policy and the formation of qualitatively new social institutions. However, so far, social policy in Ukraine is actually built on the principle of "proper response», the situational distribution of financial and organizational resources, which provide for the «removal» of the most acute social problems that may be the cause of social discontent as it is observed in most countries of the world, and therefore, can become a real threat to political stability and the whole Ukrainian society democratization course.

There are a lot of foreign literature on the analysis of social policy's models functioning in the modern democratic world countries. Such scholars as J. Buchanan, G. Epsing-Andersen, N. Furniss and T. Tilton, V. Georges and P. Wilding, R. Mishra, R. Titmuss, F. Fukuyama, etc. are of particular interest for this topic. An important basis for analyzing the problems identified in the article is the Ukrainian and Russian scholars' research where they study the state's social functions transformation problems in the democracy and globalization conditions in post-Soviet countries. They are N. Volgin, V. Gordin, V. Goshovska, A. Kolot, E. Lianov, V. Lublin, A. Krentosaska, M. Carlin and others.

However, today there is no unity among scientists in the understanding of social policy functional mechanisms regarding the objective needs' realization Ukrainian society socio-economic development. It is particularly traceable in the post-crisis economy, where there is no correlation between political and economic research, which leads to discrepancies between the Ukrainian state's political statements declaration and their real possibilities to provide.

Turning to the history of the «social state» concept's emergence it should be noted that for the first time this term was officially used in the 1949 in the Constitution of the Federal Republic of Germany and, literally, only afterwards entered into a broad scientific circle. The works of G. Ritter (Germany), K. Sole (Spain), A. Brown (USA), M. Bonetti (France) were devoted to the enlightenment of social state theoretical foundations. The «social state» concept in its content is broader than the «rightful state» concept, because it reflects not only the social freedom's degree, but also the social justice one. The social state's essence is to promote the formation of such modern society's elements as social market economy, social democracy, social ethics ${ }^{4}$.

Thus, the social market economy provides for the creation of favorable conditions for the all population's segments inclusion to the market mechanism at the microeconomic level, as well as the minimum wage

${ }^{4}$ Muzychenko G., Koliada T. Evaluation of State Intervention to the Country Economy by Global Democratic Markers. Scientific Development and Achievements. London. 2018. P. 426. 
establishment is not lower than the level of the cost of living, granting of subsidies to low-income categories of the population, the all types of social insurance development and social partnership's mechanism security.

In turn, social democracy reveals the content of various types (territorial, industrial, professional) self-government and its organic connection with the rightful state.

It should be emphasized that both the ideological process in society and the definition of role that state gives to the ideologies extension are an important features for national political regime. On our opinion, the symbiosis of at least two major political ideologies - social democratic and liberal prevails now in Ukraine. The final national ideology's determination process is still ongoing in the country, and the country's socio-economic development level plays one of the main role in it.

Thus, the social-democratic ideology based on E. Bernstein's ideas prefers state regulation of the economy and recognizes the private property economic efficiency, as well as advocates for maintaining social equilibrium by increasing budget expenders on the social sphere.

With regard to liberal ideology, it has gone through a difficult path in its evolutionary development, and now it is possible to distinguish the following approaches: classical liberalism, social liberalism, neoliberalism, liberalism. Thus, classical liberalism advocates such ideas as the absolute human value, his rights and freedoms, the rule of law and civil society, the state's non-interference in the economic and social spheres, the free market and cosmopolitanism. Social liberalism is based on J. Keynes's ideas and understands the state as an institution of universal welfare and prosperity. This approach is close to European Social Democracy in its content. In turn, neoliberalism is based on M. Friedman and F. Hayek's research. Representatives of this area criticize the state regulation of the economy as an ineffective economic, that generates disorder and corruption, defends the full privatization and market's self-regulators ideas ${ }^{5}$.

There are three established scientific and legal constructions: German model of the social and legal state (conservative-corporatists model), the Swedish model (social-democratic model) and the American model (liberal model).

According to G. Esping-Andersen's classification, modern states have proposed three possible types of reaction to global change. In the SocialDemocratic Social States (Sweden), attempts were made to maintain loyalty to the welfare policy through the jobs' creation in the public sector. The governments of these countries are trying to make an attempt to adapt the

${ }^{5}$ Масгрейв Ричард А., Масгрейв Пегги Б. Государственные финансы: теория $u$ практика. М.: Бизнес Атлас, 2009. С. 128-129. 
social state's basic directions to the changing economic characteristics of the economy management in the socio-economic globalization's context.

However, today there are increasing doubts about the viability of swedish way for solving the social state's classical principles and activity methods' adaptation problem in the modern conditions on a long-term basis.

As for the liberal model of a social state, which currently operates in the USA, the state deregulation idea is actively being implemented there.

A conservative-corporatist approach can be the third model's example that was implemented in Germany, where working places in non-productive sectors were eliminated and, in fact, the increasing unemployment strategy was chosen, in which funds are used to invest in high-performing industries and enterprises ${ }^{6}$.

As we see, the social state activity models vary not only in form but also in understanding both the mechanisms of the state of welfare ensuring and the social state developing ways a in the face of radical changes in the world political, economic, social and legal space.

Despite all of these models' differences, certain common features that reveal the social assistance essence provided by the state can be distinguished. In particular, assistance is provided if the income received is lower than the officially recognized poverty line or assets are below a certain minimum. In addition, it is intended to cover the difference between the poverty line and the real income for all who need help.

The state of welfare formation is proved to be a significant social achievement of the world civilization in the 20th century. It became a significant factor contributing to solving the economic development contradictions in the conditions of the NTR, stimulating factors of growth, productivity and innovation, and in political terms ensured social stability, contributed to the justice and solidarity principles consolidation. The age of the social state actually redirected the civilization vector, accompanied by attempts to revise the socio-economic growth principles and the state's role, changing the national income redistribution nature.

However, society does not stand in one place, but it constantly develops under the pressure of many factors, both political and economic, which necessitate the policy update. Social policy modernization is a natural and necessary process due to the economy and social structure transformation. Russian researcher V. V. Lublin pointed that in the 1970's the West's development long-term cycle connected with the social state's mechanisms formation had come to the end. However, in the time following, the previous

${ }^{6}$ Koliada T., Muzychenko G. Transformation of the role of state in economy of Ukraine from the respective of Euro-integration process. European integration processes in the $21^{\text {st }}$ century: key trends, major challenges and new opportunities. 2018. Kyiv: Ukrainian Association of Teachers and Researchers for European Integration, pp. 276-287. 
economic development conditions had undergone significant changes, which led to the beginning of a new social state's development stage, whose boundaries are largely determined by both the world economic processes' transformation and the modern countries political and ideological development's course ${ }^{7}$.

According to the Western researchers' position, the main problem now is that the state loses the ability to control the process of capital transfer. The industrially advanced countries' governments, which tried to combat unemployment, had to make a concerted turn to the "supply-side policy». The goal was to set a minimum level of return for productive investment above that provided in international markets. One of the main points in this scheme is that it is becoming increasingly difficult to finance «big social policy», since the necessary borrowing in the new environment becomes more costly compared to the previous period when governments were more likely to attract additional resources. From certain time, these changes began to form the strategy's boundaries aimed at changing the state's role and functions in the economy and social development.

Such a policy is aimed at transforming the model, based on the new context of interaction between different industry and corporate interests, social partners and social groups. One of the key aspects is the change in the balance between factors of production (capital and labor), which is reflected in the entrepreneurs' position strengthening at the society level and the main state's efforts are aimed at increasing the competition policy effectiveness.

Therefore, now Ukraine faces a choice which role the state should play in the economic processes' regulation in the country and depending on the solution to this question, which ideology it should prevail in the public life development. However, it should be emphasized that in Ukraine, as a democratic state, at the Constitution level has established that the social life is based on the political, economic and ideological diversity principles (Part 1, Article 15). This means that no ideology can be recognized by the state as obligatory: the Ukrainian state creates different conditions for the different ideologies development, except, of course, an ideology that is anti-state in its content and essence ${ }^{8}$.

Excessive state interference in redistributive processes, equalization of income through social transfers leads to a decrease in business activity in society and a reduction in the production efficiency in general. On the other

${ }^{7}$ Коляда Т. А. Фінансове забезпечення соціальних функцій держави в умовах посткризової трансформації соціально-економічної системи. Наукові записки. Серія «економіка»: збірник наукових праџь Наџіонального університету «Острозька академія», 2012. Вип. 20. С. 84.

${ }^{8}$ Muzychenko G., Koliada T., Churkina I. Impact of European Integration Process on the Necessity of Long-Term Budget Planning Introduction in Ukraine. Baltic Journal of Economic Studies, 2017, no.3 (5), pp. 330. 
hand, the state's role reducing in regulating household incomes leads to an increase in income differentiation, social tension, social conflicts' aggravation and, as a result, drop in production, lowering its efficiency. The achievement of the state interference optimal scale in the social relations' regulation in society is associated with the resolution of the contradiction between efficiency and social justice.

Thus, the state's social policy in a market economy should be a very subtle tool. On the one hand, it is intended to promote social stability and mitigate social tensions, and on the other hand, in no way undermine the entrepreneurship's stimulus-reaction and highly effective employment.

\section{Ukraine in the context of European standards of state regulation of economic development}

Global economy changes have forced the scientific community to return to basic questions about the state: what should be its role, task, function, because the sustainable development - both economic and social - is impossible without an effective state. The lack of an adequate theoretical basis for interpreting the state's role and its functions in national economies negatively affected the prospects of exit from the structural and financial crisis ${ }^{9}$.

In the current multifaceted, mixed market economy, the state plays an active role in shaping the most important processes of socio-economic development. The public sector has a dominant position in the economy due to using resources to finance state-guaranteed public services and various income redistribution programs. The public sector also plays an important role in the financial markets of most countries, owing to significant amounts of its borrowing from the private sector and a substantial amount of its assets in the economy. The public services financing and the income redistribution in most countries of the Organization for Economic Cooperation and Development (OECD) exceeds $40 \%$ of GDP, and in some countries it even approaches $50 \%$ of $\mathrm{GDP}^{10}$. The state's influence magnitude is particularly increasing in the period of aggravation of the economic and social situation in the country. In periods of stable development and absence of crises, the scale of government influence is shrinking and the state, like other market agents, operates within defined long-term programs and strategies.

The level of state interference in the country's economy is determined by the share of GDP redistributed through the budget. Today there is no consensus among scholars regarding the determination of the optimum budget

${ }^{9}$ Масгрейв Ричард А., Масгрейв Пегги Б. Государственные финансы: теория $u$ практика. М.: Бизнес Атлас, 2009. С. 112.

${ }^{10}$ Muzychenko G., Koliada T. Evaluation of State Intervention to the Country Economy by Global Democratic Markers. Scientific Development and Achievements. London, 2018, pp. 431-432. 
size and its structure. The scientific sources analysis shows that a significant part of the key issues in determining the optimal size of budget expenditures for a given country with all its internal and external factors remain unresolved. Therefore, every year during the process of Ukraine's fiscal policy main directions defining for the relevant year, scholars and experts discuss the main fiscal policy parameter - the share of GDP redistribution through the consolidated budget.

The famous American scientist Richard Masgrave noted: «More than 20 percent of the gross national product (GNP) in the USA is consumed by the government today. Total state expenditures, including transfers, forming to 35 percent of GNP, and tax revenues - more than 30 percent of GNP. Despite this, the state participation in the US economy in comparison with other developed countries is not so significant. For example, in Western Europe, more than half of economic activity is in the public sector. In addition to budget functions, state policy influences the course of economic activity through monetary, power and other mechanisms» ${ }^{11}$.

Budget and GDP ratio - an important economic problem, due to the particular state economy model functioning' peculiarities. Ukraine has been showing a tendency to increase the consolidated budget expenditures in recent years. By itself, this fact is not threatening because the average government spending in developed countries has a wide range of differences - from 30 to $60 \%$ of GDP, which does not prevent a sufficiently high level of well-being of the population. However, in Ukraine, as in most emerging market countries, there are certain peculiarities in socio-economic development, which requires scientific substantiation and determination of economic expediency in relation to increase of budget expenditures.

The growth of the state's role in the income redistribution is inherent in all European countries. Their common feature is a significant share of public expenditure in GDP. It can be argued that in most countries with a developed market economy, the indicators characterizing the budgetary burden are comparable. Due to the integration of economic, financial, currency, and credit systems in European countries, the convergence process has taken place equalizing the value of financial and budgetary indicators, in particular, the budget deficit, public debt, inflation, interest rates, etc. Among the main benefits of such integration is the coordinated, even development of all EU Member States. The disadvantage of such an association is the particular country government inability to accelerate its own economy development.

Based on the analysis of only the above indicators, it can be noted that the state's role in the Ukrainian economy is rather high. Thus, in 2017 the share of state expenditures with the Pension Fund in GDP in our country was

${ }^{11}$ Масгрейв Ричард А., Масгрейв Пегги Б. Государственные финансы: теория $и$ практика. М.: Бизнес Атлас, 2009. С. 17. 
42.5\%. Unfortunately, the state's economic regulating mechanism capacity remains unsatisfactory and requires immediate reform.

The prominent American economist, winner of the Nobel Prize for Economics (1970) Paul Samuelson noted: «Democracy generates a state that is desirable to it. Unfortunately, the history will answer two questions - is the extension of the state's powers good or bad policy, and whether it should receive approval from all who are sincerely interested in preserving and improving the positive aspects of our system - after a long time only. In politics, as in any other area, it is true that the road to Hell is paved with good intentions» ${ }^{12}$.

In order to ensure the economy's growth, Ukraine has actually exhausted all possibilities to expand the range of state functions in terms of their budget financing. Thus, some scholars believe that for our country the optimum or reverse of the state consumption volume is $25-27 \%$ of GDP, while others define it at the level of 32-33\% of GDP (excluding social transfers). A further public spending increasing is already threatening the country's development. Especially during the world economy recession, which occurs in modern conditions, it is necessary to reduce budget expenditures.

In this regard, the present condition and the near-term outlook of the budgetary burden on the Ukrainian economy are of particular interest. It must be agreed with the many experts' opinion that when calculating the budget burden indicator, it should been taken into account not only the Consolidated Budget revenues, but the extrabudgetary funds as well (Table 1).

Table 1

Budget burden in EU-28 countries and Ukraine, \% of GDP

\begin{tabular}{|l|c|c|c|c|c|c|c|c|}
\hline \multicolumn{1}{|c|}{ Indicators } & $\mathbf{2 0 1 0}$ & $\mathbf{2 0 1 1}$ & $\mathbf{2 0 1 2}$ & $\mathbf{2 0 1 3}$ & $\mathbf{2 0 1 4}$ & $\mathbf{2 0 1 5}$ & $\mathbf{2 0 1 6}$ & $\mathbf{2 0 1 7}$ \\
\hline EU-28 countries & 50,0 & 48,6 & 49,0 & 48,6 & 48,2 & 47,4 & 47,2 & 46,9 \\
\hline Ukraine & 45,9 & 42,7 & 46,1 & 46,3 & 44,6 & 45,0 & 45,8 & 45,2 \\
\hline
\end{tabular}

Source: compiled according to the statistics of the European Union (http://appsso.eurostat.ec.europa.eu) and the State Statistics Service of Ukraine (http://www.Ukrstat.org)

In order to compare the EU countries and Ukraine budget structure indicators correctly, the amount of deductions to extrabudgetary funds (pension and social), which were also reflected in the social benefits indicator, was added to the Ukrainian budget expenditures.

According to the data, the budgetary burden in Ukraine is slightly lower than in the EU zone's countries, but the domestic indicator is characterized by considerable volatility and the opposite trend direction for its

\footnotetext{
${ }^{12}$ Самуэльсон П. Экономика. Москва: МГП «Алгон» ВНИИСИ, 1992. Т. 1. С. 152.
} 
changes. If in European countries there is a tendency to decrease or stabilize the growth rates of budget expenditures, in Ukraine, their uneven gradual growth occurs.

Before consolidating the budget and looking for mechanisms for its implementation, it is necessary to clearly determine at the state level what the demand or supply economy the government is trying to build in the country, since it will depend on the choice of directions and volumes of budget funds spending.

Demand economy provides for significant state subsidies (including social transfers) from the budget to support aggregate demand in the country. In order to have a multiplier effect of spending budget funds, it is necessary to limit the volume of imports to the country and thereby stop the outflow of currency from the country. It will be problematically to do it in the context of Ukraine's accession to the WTO. In addition, in order to surmounting the crisis, it is necessary to direct budgetary funds for investments, not for consumption.

In Ukraine it is necessary to develop the economy of supply through the introduction of import substitution of technologies and increase of domestic goods and services' volumes. Such economy's model implies an increase in the public investment volume in innovative and infrastructure projects, which will lead to an increase in public debt, with the effect only tangible in the medium and long term.

The all leading countries' governments have faced with the impossibility of constantly stimulating demand in the context of the global economic recession. Due to restrictions on public investment, falling living standards, reducing the private investment volume and the unavailability of credit resources, the proposals to return production to the metropolis are increasingly being heard as one of the options for anti-crisis maneuver of states, which can reduce unemployment and create new jobs.

Actually, there is a question for the world about the transition to a new model for building economic relations - the economy of the proposal, which involves modernization as a basis - production, and its superstructure the nature of public relations. And the fiscal policy forms and reflects the type of state economic model.

Regarding the main economic development indicator - the GDP growth rate, there is no consensus among scientists on the budget expenditures impact on the rate of economic growth, because each country has its own optimum in the size of public expenditures. This indicator is affected by many factors, in particular, the structure of expenditures, the economic development cyclicality, the external markets situation, and the energy's cost for Ukraine as well. 
Scientists have proven that the multiplier of reduces budget expenditures by $1 \%$ leads to an average GDP drop of $1.7 \%$. According to IMF's experts calculations, the GDP rate is declined today within the range of $1.5-2 \%$ of GDP. In addition, the financial resources global redistribution mechanism calls into question the existence of a direct correlation between GDP growth rates in a particular country and the results of this growth. Therefore, forecasts are made that the economic development of countries in the present conditions should take place through fiscal consolidation, at least during the next 15 years. The growth of world GDP will be achieved by countries with growing consumption markets. Today in the world there are 20 fast-growing countries, for which markets must be fought, because now a new global system of economic growth is being created in the world ${ }^{13}$.

In this regard, J. Stiglitz warns that when the government cuts costs, there is a slowdown in economic growth, an increase in unemployment and a reduction in incomes, which leads to a reduction in tax revenues. The state budget eventually gain nothing or improve slightly. However, there is one way out from this difficult situation. Concerns about the amount of debt should lead to a change in the structure of public spending, to costs that bring high economic returns. But borrowing to finance investments (for example, in technology, infrastructure and education) with a profitability of 5 or $6 \%$ can lead to a reduction in long-term national debt, as growth, both in the short and long term, will bring more than enough additional tax revenues to pay interest rates ${ }^{14}$.

The current state expenditures reduction signals to financial market participants about the increasing of confidence in government actions in the long-term outlook by reducing the budget deficit, which in turn will contribute to an increase in aggregate demand in the country. On the other hand, the reduction of expenditure items of lower political significance, such as budget investments, will have a weaker effect on the degree of confidence in the proposed measures. Thus, when making managerial decisions regarding the budget expenditures reduction in order to balance the budget and reduce its deficit it is advisable to give priority to measures aimed at reducing current expenditure's items, since this will have a more positive effect on the economic development's pace than the public investment reduction.

The state must concentrate its limited resources on clearly defined basic functions. Budget policy should be based on the relative state participation effectiveness assessment in various economic activity's spheres and minimize

${ }^{13}$ Koliada T., Muzychenko G. Transformation of the role of state in economy of Ukraine from the respective of Euro-integration process. European integration processes in the $21^{\text {st }}$ century: key trends, major challenges and new opportunities. 2018. Kyiv: Ukrainian Association of Teachers and Researchers for European Integration, P. 284.

${ }^{14}$ Стиглиц Дж. Е. Крутое пике: Америка и новый экономический порядок после глобального кризисна. М. : Эксмо, 2011. С. 373. 
the budgetary resources distribution in areas where the state's participation is unnecessary or ineffective.

In the context of the globalization and the transparency of most economies in the world, when crises are of an all-embracing nature, and among the factors that trigger them the institutional ones become dominate, we must talk about the decisive role of the state in overcoming the crisis phenomena, the need for intervention in market mechanisms and the introduction of manual control of the situation. At the same time, it should be emphasized that the modern socio-economic structure of Ukraine, which was formed as the economy institutional transformation result, is characterized by the strengthening of the state's role as a public goods producer, as is the case for most European countries.

The governments of the countries that systematically undertake longterm budget forecasts have developed effective measures to ensure the state sustainable development through the pension systems' restructuring or the creation of special funds for future needs. Publicity and availability of information about long-term sustainable development trends is a prerequisite for obtaining public support and confidence from the government's efforts to reduce the long-term budgetary tension. There is a high probability that the government's previous measures to expand fiscal space are outdated due to the lack of transparency in obtaining information for forecasting and their inability to minimize political pressure for reform. But all countries that have already introduced budget strategic planning and benefited from its use are optimistic about their ability to effectively manage the public regulation of the economy until the next state of emergency in the budget sphere arises in the future.

\section{CONCLUSION}

During making managerial decisions in democratic societies it is necessary to find a compromise between the state and the population of the country - taxpayers and public services recipients, since the public good value is determined by the subjective and psychological assessments of its consumers. Lack of the state government trust on the part of the population may ignore the implementation of the proposed "rules of the game" by changing the taxpayer's jurisdiction, switching to shadow business practices, increasing consumer confidence in society, or even switching to open actions disobedience that will lead to the emergence threats to fiscal stability in the country.

Unfortunately, the change in the social way of life in Ukraine was not ensured by appropriate economy modernization and rethinking the nature of the relationship between the state and society over the volume of guaranteed public goods and services provision. The lack of an inventory of social privileges (benefits) that the state provides to its citizens allows certain citizens categories to use several of them simultaneously, which adversely 
affects the implementation of the budget system's fairness and impartiality principle and generates consumer sentiment in society.

In the context of fiscal consolidation and post-crisis economic recession, it is imperative to reduce the social benefits list and state support directions, which will increase those remaining benefits' financing and increase the public services' efficiency and quality. At the same time, the social benefits' total amount received by one person per month can not be higher than the subsistence minimum. It is necessary to legislatively fix restrictions on the maximum for the social assistance's amount per person. It is also necessary to determine clearly which categories of citizens need state social assistance and on what criteria such categories of population will be determined.

It is necessary to return to the ideology that a person should work to keep himself and his family safe if he has no restrictions on his health or for other reasons. The state is not obliged to give money to citizens, but only to create conditions for obtaining work. Therefore, the priority task is to prepare public opinion for the transition to a new model of relations with the state. Such an initiative should come not only from the state, it is necessary to involve public organizations and scientists to explain the irreversibility and the need for such transformations, to highlight the benefits that citizens of most democratic and market-rich countries of the world already have.

The reduction of current state expenditures signals to financial market participants about the increasing of confidence in government actions in the long-term outlook by reducing the budget deficit, which in turn will contribute to an increase in aggregate demand in the country. On the other hand, the reduction of expenditure items of lower political significance, such as budget investments, will have a weaker effect on the degree of confidence in the proposed measures. Thus, when making managerial decisions regarding the reduction of budget expenditures in order to balance the budget and reduce its deficit it is advisable to give priority to measures aimed at reducing current items of expenditure, since this will have a more positive effect on the pace of economic development than the reduction of public investment.

The state must concentrate its limited resources on clearly defined basic functions. Budget policy should be based on the assessment of the relative effectiveness of state participation in various spheres of economic activity and minimize the distribution of budgetary resources in areas where the participation of the state is unnecessary or ineffective.

In the context of the globalization and the transparency of most economies in the world, when crises are of an all-embracing nature, and among the factors that trigger them the institutional ones become dominate, we must talk about the decisive role of the state in overcoming the crisis phenomena, the need for intervention in market mechanisms and the 
introduction of manual control of the situation. At the same time, it should be emphasized that the modern socio-economic structure of Ukraine, which was formed as a result of the institutional transformation of the economy, is characterized by the strengthening of the role of the state as a producer of public goods, as is the case for most European countries.

\section{SUMMARY}

The article has a deal with the evaluation of the state intervention range to the economy of modern countries and Ukraine as well. It is pointed the new state social policy priorities, caused by changes in the social structure of society and the global shift in the market for factors of production (capital and labor) in the context of globalization.

The essence of the European integration processes' influence on the transformation of the state's role and tasks in regulating the economic situation in Ukraine is revealed. It is determined that the state as an institution acquired new qualities due to the growing interdependence of the state and the economy in the conditions of globalization. The objective and irreversible strengthening of the state role in overcoming the crisis phenomena in the economy, which is accompanied by a change in the nature of the national income redistribution and the budget and GDP ratio is proved.

It is substantiated the necessity of preparing public opinion for the transition to a new model of relations with the state, based on the domination of ideology that a person must work to keep himself and his family safe if he has no restrictions on health or for other reasons. The state only has to create conditions for work. The irreversibility and necessity of such transformations is confirmed by the experience of most of the democratic and market-driven countries of the world.

\section{REFERENCES}

1. Гальчинський А. Вилікувати економіку можна тільки на ліберальних засадах. URL: http://www.dt.ua/2000/2020/68567/

2. Гальчинський А. Tри кроки бюджетної політики. URL: http://www.dt.ua/publications/2006/09/15/241731/

3. Коляда Т. А. Формування бюджетної стратегї Украӥни: теорія, методологія, практика. Ірпінь : Університет ДФС України, 2016. $396 \mathrm{c}$.

4. Коляда Т. А. Фінансове забезпечення соціальних функцій держави в умовах посткризової трансформації соціально-економічної системи. Наукові записки. Серія «економіка»: збірник наукових праць Національного університету «Острозька академія», 2012. Вип. 20. C. 81-86. 
5. Масгрейв Ричард А., Масгрейв Пегги Б. Государственные финансы: теория и практика. М.: Бизнес Атлас, 2009. 716 с.

6. Музиченко Г. В. Вплив сучасних світових соціальноекономічних процесів на зміст соціальної політики держави. Науковий вісник. Одеський державний економічний університет. Всеукраӥнська асоціація молодих науковиів. Науки: економіка, політологія, історія. 2011. № 9 (134). С. 181-189.

7. Самуэльсон П. Экономика. Москва: МГП «Алгон» ВНИИСИ, 1992. T. $1.333 \mathrm{c}$.

8. Стиглиц Дж. Е. Крутое пике: Америка и новый экономический порядок после глобального кризисна. М. : Эксмо, 2011. $512 \mathrm{c.}$

9. Шахова Г. Я. Методологические особенности долгосрочного бюджетного планирования: мировой опыт. Финансовый журнал. 2009. № 2. C. 99-108.

10. Фінанси: Навч. посіб. К.: Знання, 2006. 415 с.

11. Koliada T., Muzychenko G. Transformation of the role of state in economy of Ukraine from the respective of Euro-integration process. European integration processes in the 21st century: key trends, major challenges and new opportunities. 2018. Kyiv: Ukrainian Association of Teachers and Researchers for European Integration, pp. 276-287.

12. Muzychenko G., Koliada T., Churkina I. Impact of European Integration Process on the Necessity of Long-Term Budget Planning Introduction in Ukraine. Baltic Journal of Economic Studies, 2017, no. 3 (5), pp. 329-333.

13. Muzychenko G., Koliada T. Evaluation of State Intervention to the Country Economy by Global Democratic Markers. Scientific Development and Achievements. - London, 2018, pp. 421-432.

14. Zeldner, A. State and market: strategy of development of economic relations. Announcer of Institute of economy of Russian Academy of Sciences, 2007. Vol. 3, p. 5-13.

\section{Information about the author: Muzychenko G. V.,} Doctor of Political Sciences, Professor at the Department of Political Sciences and Law, South Ukrainian National Pedagogical University named after K. D. Ushynsky 26, Starofrankivska str., Odessa, 65020, Ukraine 


\section{STATIST IDENTIFICATION OF CITIZENS AS A STABILIZATION FACTOR FOR UKRAINIAN SOCIETY}

\section{Pashyna N. P.}

\section{INTRODUCTION}

The issue of consolidated political identity is one of the most challenging in the period of independence of the Ukrainian state. This is conditioned by the fact that strengthening of the political nation, solution of the tasks of demographic transformation is possible due to the general identity milestones of the most population. At the same time, this process cannot be considered to be completed. The risk of emergence and extension of conflicts in the society on the grounds of discernible differences between citizens of some regions related to priority directions of the internal and external development maintains its relevance ${ }^{1}$.

Political practice shows that regional polarity emerges full blown in the epoch of crisis and changes when it is essential to unite and mobilize the society for solving socially important tasks. It becomes a subject-matter of the goal-directed influence of the state, political elites and interest groups. Ethnic and regional identity in that period is dominant in the processes of political identity formation. Election campaigns of the XXI century and tragic events at south-eastern Ukraine, which began in 2014, are an example of the use of regional differences for political expediency. During one decade and a half, the groundwork of political struggle in Ukraine was not a conceptual competition but conflict technologies based on modeling of "enemy image", the division of Ukraine into regional segments, the use of construction "two Ukraines" by political managers. In the context of exacerbation of crisis developments, such ideas have exceptionally fertile ground in the economic and social areas and become a significant factor in shaping the ethnic-regional political identity ${ }^{2}$. Regional identification models are on the rise and intensively established, including through a political elite. And there is a growing emphasis on the local socio-cultural contrasts, social-class confrontations.

Thus, the analysis of shaping political identity in Ukraine shows that there are needs and considerable disagreements between the regions of Ukraine concerning the issues of social development due to some problems.

${ }^{1}$ Ідентичність громадян України: зміни, тенденції, регіональні особливості. Національна безпека і оборона. 2016. № 3-4 (161-162). С. 22-58.

${ }^{2}$ Панчук М. Етнополітичні процеси в Украӥні: регіональні особливості. Київ: Інститут політичних і етнонаціональних досліджень ім. І.Ф. Кураса НАН України, 2011. С. 203. 
Comparing East and West of Ukraine, they are manifested in the electoral strengths, geopolitical orientations, evaluation of the historical background and language-based problems etc. more vividly. Ethnic-cultural regionalism creates additional difficulties in the forming of nationwide identity, consolidation of Ukrainian society towards strategic social development goals: its democratization and modernization.

Consequently, the building of nationwide identity under the conditions of sensitive regions in terms of the ethical and religious composition is one of the urgent problems of modern Ukraine.

Collective political identity (nationwide, national, civil) is a basis for the consolidation of citizens regarding the core social values. Taking into account the above, the shaping of collective nationwide forms of a political identity, which ensure the settling of political system, regimes and the entire society, is the crucial policy direction of contemporary states.

The research of J. Linz, G. Minenkov, E. Pain, V. Safran, A. Stepan, I. Yadav was devoted to the agenda of identity policy in the multiconfessional, multicultural and multilingual states of the modern world, solution of identity conflicts. The papers of R. Dahrendorf, Th. Carothers, A. Lijphart, $\mathrm{S}$. Huntington consider the problems of development and strengthening of democratic regimes, consolidation in complex, multicultural, sociofragmented states. The papers of Yu. Koki, I. Neumann, J. Habermas, F. Cerruti are devoted to the constructing of Pan-European identity.

Scientific discourse on the problems of forming a national-civic identity as a necessary resource for stabilizing a social system, consolidation of Ukrainian society is currently of immediate interest in Ukrainian political science. The above fact is supported by many recent publications and research with a focus on nationwide identity ${ }^{3}$.

\section{The role and significance of macro-political identity for stabilizing society}

Identity is based on the mechanisms of differentiation and identification. Identity grows out of the comparison of "Self" with "Other" where "Other" may be defined as Enemy or Friend. Identity is a result of the identification process which exercises the functions of self-description and

3 Україна: шлях до консолідації суспільства: національна доповідь. Інститут політичних і етнонаціональних досліджень ім. І. Ф. Кураса НАН України. Київ : НАН України, 2017. 336 с.; Ідентичність громадян України в нових умовах: стан, тенденції, регіональні особливості. Український центр економічних і політичних досліджень імені Олександра Разумкова. 2016. № 3-4 (161-162). URL: http://razumkov.org.ua/uploads/journal/ ukr/NSD161-162_2016_ukr.pdf; Основні засади та шляхи формування спільної ідентичності громадян України. Український центр економічних і політичних досліджень імені Олександра Разумкова. 2017. № 1-2 (169-170). URL: http://razumkov.org.ua/uploads/journal/ukr/ NSD169-170_2017_ukr.pdf. 
self-determination. Thus, identity may be considered as a result of the identification process, which shows the psychological and social mechanisms of identity constructing, and defined in general as a process of establishment, functioning and development of the identity of the subject. The characteristic of the actorness is its subject-role, functional, constructed nature.

Political identity may be regarded as an individual kind of social identity. In nature, it is balanced and reflexive together. Holding certain status position, a person compares his state, a system of political spots and values with other individuals and political objects, namely, the state, parties, interest groups, public movements etc.

Not only the study of individual types of political identity but also considering of the globalization processes, intensification of migration movements, amplification of the social structure, the emergence of new identification codes of its collective forms, especially in the complex states is relevant to modern science. Motivating the political behaviour, political identity, nowhere more so than in its collective macro-forms, determines the direction and is the most important resource of the political development, ensures the stability of the political regime and political system. And vice versa, the lack of collective forms of political identity at the macro-level exacerbates political contradictions in complex states and is a trigger for political turmoil, separatist tendencies, a threat to political security.

To study the collective forms of identity at the domestic level, in political science, it is expedient to use the terms "macro-political identity" which can have various forms (types): country-wide, national, civil, public. The essence of such a definition, as an analysis tool, is all about the universal denominator of collective identities, option to describe general processes, tools and mechanisms for their shaping ${ }^{4}$.

Each of the forms of macro-political identity unites the society in its way, contributes to the political stabilization, and bridges sectional controversies. A. Lijphart marks four factors of political stability: support of the system, civil order, legitimacy and effectiveness, which are closely related and predetermine each other ${ }^{5}$.

The role and significance of the macro-political identity for a stable development are defined by the functions it performs within society. First of all, this is the integration and consolidation of the citizens of segmented society based on the shared goals and values that impede disintegration and destabilization processes.

${ }^{4}$ Угрин Л. Я. Ідентичність і безпека: проблеми співвідношення в контексті соціального конструктивізму. Гілея: науковий вісник. 2016. Вип. 111. С. 329-333.

${ }^{5}$ Лейпхарт А. Демократия в многосоставных обществах: сравнительное исследование. Москва : Аспект-пресс, 1997. 288 с. 
Support of national goals and values by the majority of citizens, despite political and socio-cultural differences, indicates the existence of macro-political identity as a basic foundation that ensures the stability and continuity of the social system. At the same time, the setting of common goals and values is the result of public consensus and compromise. It is shared by most of the citizens and political elites and supported by the state through the implementation of policies in various public spheres. That tandem of society and state acts as "a persistent rod" - it is an important factor for a sustainable society.

If the formed macro-political identity is a stability factor in society, then the crisis (lack) of macro-political identity (e.g. under the change of political regime, dissipation of a state) due to the busting of common sociocultural and political myths, restructuring of the symbolic space is a danger to the community because it loses its benchmarks, the capacity to collective action. Crisis identity is often characterized by the predominance of a negative model of identity, the domination of the image of Enemy in the public consciousness, the generation of "a negative mobilization" 6 .

A consolidation of citizens based on hatred and fear, xenophobia growth, uncontrolled aggression against representatives of other political beliefs, socio-cultural minorities is a destructive factor in the development of a society that obstructs overcoming the crisis. Identity crisis causes the loss of the international actorness and geopolitical positions.

An agreement on the fundamental strategic issues of the development envisages the coherence of socio-political conduct with its modeling in a favorable direction to the state. "Imagined community" satisfies the majority of community members, ensures the government legitimacy, the vital activity of a political system and regime as a whole.

Macro-political identity based on the "imagined community" involves adjusting of the political system and community members to the available internal and external conditions, taking into account mutual interests of most participants of the political process.

One shouldn't ignore the psychotherapeutic role of macro-political identity. According to A. Maslow, safety need is a basic human need ${ }^{7}$. Joined the macro-collective majority, community members assure themselves of security, confidence, inner comfort. From the viewpoint of E. NoelleNeumann, political self-identification of citizens is the satisfaction of the need for recognition. The author believes that the need for recognition can play a

${ }^{6}$ Гудков Л. Н. К проблеме негативной идентификации. Гудков Л. Н. Негативная идентичность: статьи 1997-2002 годов. Москва : Новое литературное обозрение, «ВЦИОМ-А», 2004. С. 262-299.

${ }^{7}$ Маслоу А. Мотивация и личность. Санкт-Петербург : Евразия, 1999. 478 с. 
motivation role for political behaviour, assist in the transformation of activity needs, help people to feel familiar with political space and evaluate it ${ }^{8}$.

In general, macro-political identity as a mental indicator defines the real territorial boundaries of the community that determines some values and symbols as $\mathrm{Own}^{9}$.

Political identity in the postmodern society is a subject-matter of identity policy which can be exercised by all actors of the political process able to formulate and defend the interests of social groups or society as a whole. It is implemented following the principles of pluralism and stipulates that identities compete with each other, and identification of social actors is performed on the ground of "recognition".

Identity politics can be defined as a system of measures and actions of the actors of a political process designed to form a collective identity based on the promotion of some goals and values, clarification of the essence "We" and marking "Other".

However, the concept "identity politics" is mainly used in the science and public discourses to analyse government action (policy) on constructing, consolidating and correcting of macro-political identity in terms of promotion of some goals and values, clarification of the essence "We" and marking "Other". The above is basically realized in the ideological and humanitarian areas and, at the same time, media space is of key importance ${ }^{10}$.

The dominant role of the state in the process of shaping political identity on a nationwide scale is defined by the fact that it has all required political, legal, administrative, economic, information and other resources at its disposal. The state also owns such a network of institutionalized channels for the implementation of collective identity as state symbols, science, academic and educational institutions, state media, libraries, museums etc.

Thus, the national identity politics means a complex of political decisions, measures and actions on the part of the state which are intended to build collective nationwide identity through relevant influence technologies.

At the same time, the constructing of political identity using available state resources (political, economic, administrative, communicative, educational) is limited by cultural and historical factors, which were developed due to the mentality of most of society, political traditions, and have peculiar characteristics in different countries.

\footnotetext{
${ }^{8}$ Ноэль-Нойман Э. Общественное мнение : открытие спирали молчания. Москва: Прогресс-Академия, ВесьМир, 1996. С. 74-95.

${ }^{9}$ Угрин Л. Я. Ідентичність і безпека: проблеми співвідношення в контексті соціального конструктивізму. Гілея: науковий вісник. 2016. Вип. 111. С. 329-333.

${ }^{10}$ Пашина Н. П. Політика ідентичності: сутність та функції формування. Науковий часопис НПУ імені М. П. Драгоманова. Серія 22 : Політичні науки та методика викладання сочіально-політичних дисциплін. 2015. Вип. 17. С. 88-93.
} 
Identity politics focused on the formation of macro-political identity includes not only the cultural framework of the society - it deals with all aspects of social life related to the creation of the positive collective macropolitical identity. Thus, in the political dimension, first of all, this is the case of consensus about social development goals, elite continuity in defining the core of identity politics - these are political rights and freedoms; in the legal area, these are equality before the law; in economics - the creation of equal opportunities to exercise the needs and abilities; in the social sphere - the building of the system of social guarantees and social protection of citizens etc. In general, identity politics should be aimed at cultivating a positive image of the state (or supranational community) in all activity areas.

The experience of consolidated states shows that cornerstone of their identity politics is the values of democracy and rule-of-law state. At the same time, according to R. Inglehart and Ch. Welzel, if there are threats to the vital interests, "pro-democracy values emphasizing self-expression are not capable of rooting" "11. For this very reason, the essential component of modern identity politics is poverty reduction, an increase of employment level of able-bodied population, social guarantees, the establishment of high standards of living and psychological comfort.

The policy of macro-political identity should include the definition of policy models, strategy, tools and mechanisms. Considerable importance belongs to the legislative consolidation of strategic aims of identity politics, implementation of special programs, joining other actors of the political process: political parties, public movements, mass media, institutes of public society etc.

The challenges of modern epoch in the form of globalization processes, dissolving national boundaries complicate the act of identification and hierarchy of identities in the consciousness of identification subjects. A famous Polish-Britain political philosopher and sociologist Z. Bauman highlights that the modern era has given over having the determinacy nature; he characterizes its mobility as "a rare modernity" which is spinning out of control. "In our era of "rare modernity", the world around us is divided into poorly coordinated fragments while our individual lives are cut into many loosely bound episodes”. Thus, the author believes that identity is not an individual problem but a series of problems ${ }^{12}$.

On the one hand, new tools for the formation of macro-political identity are emerging in the states, e.g. electronic and digital media, information management, on the other hand, the competition with other actors influencing the identification process in the form of online communities, various platforms

${ }^{11}$ Инглхарт Р. Модернизация, культурные изменения и демократия: Последовательность человеческого развития. Москва: Новое издательство, 2011. С. 237.

${ }^{12}$ Bauman Z. Identity. Cambridge : Malden, 2004. P. 12-13. 
and Internet applications, fashionable sites and bloggers becomes more complicated. Such external factors as hybrid wars, the technology of "soft power", "behavioural wars" on the technologies of influence interested in geopolitical actors have a major impact on identity transformation.

The problems of constructing the political identity at the macro-level of plural societies, specification of tools for the creation of the common field for representatives of different cultural and political beliefs gain a peculiar currency in the modern communities. At the same time, reliance on culturalcivilizational and public priorities available in the society is the prominent mechanism for the shaping collective nationwide identity model.

Plural society means the division of society into segments of ideological, cultural, religious, regional, racial, national character. In G. Eckstein's opinion, a plural society is divided by "segmental contradictions", and political disputes mainly coincide with the most critical lines of social division ${ }^{13}$. Therefore, the integration of such a society under a common political denominator in the form of the shared goals and values is more complex compared to society more homogeneous in its structure. It doesn't mean that it is impossible to achieve unity with the goals and values most important for society, which are the basis for the formation of collective macro-identity, in the plural societies. Such plural societies as Switzerland, Austria, Netherlands, Belgium are an example of the successful consolidation. Democracy values and collaboration of elites is the foundation stone of their political stability ${ }^{14}$.

\section{Statist identity as a resource for sustainable development}

The formation and reproduction of collective types of identity have a double pillar: institutional and ideological. Institutional pillar is associated with the fact that collective actorness of communities rests on a certain organization - state, church or based on cultural communication (one which has clear institutional features - language, literature, art, science, education, folklore tradition, the phenomenon of the cultural elite, etc.). Ideological pillar lies in the identification of an individual with a community relies on its assimilation of the concept of common origin, collective mission, unifying values, significant differences from other communities of the same type. In view of the foregoing, modern scientists define a certain type of identity as one characterizing a person's belonging to the imagined community ${ }^{15}$.

${ }^{13}$ Lehmbruch G. Segmented Pluralism and Political Strategies in Continental Europe: Internal and External Conditions of «Concordant Democracy». Paper presented at the Round Table of the International Political Science Association, Turin. 1969. September. Pp. 1-2.

${ }^{14}$ Ibid. Pp. 141-144.

${ }^{15}$ Україна: політичні стратегії модернізації : зб. науково-аналітичних доп. / за ред. М. М. Розумного (заг. ред.), О. А. Корнієвського, В. М. Яблонського, С. О. Янішевського. К. : НІСД, 2011. С. 7. 
For example, civil identity is a specific mechanism of individual socialization - its essence is a conscious identification of own fate with the fate of a particular country. It is marked by the participation in public affairs, political competence, tolerance and respect for the freedom and dignity of other citizens, the drive for democratic security. This requires the recognition of the decisive nature of the factors of nation creation, the positive effect of which is connected with tolerance, solidarity, loyalty, non-tolerance of xenophobia and chauvinism.

Endorsing the idea on topmost importance of the formation of common political civic identity of the country, we believe that it should be specified as a statist but not civic.

In the context of contemporary political development, statist identity may be defined as identification of a person with national state community, values that prioritize the duties and rights of other members of the community and the state ${ }^{16}$.

The above definition looks more correct, taking into account the fact that the concept "civic" has different dimensions, and one should explain what level and type of "community" is meant when using it - village, city, region, ethnos or the whole state. Moreover, most manuscripts of Ukrainian authors represent the civic identity as an individual category, not collective, which is related to a certain social role, position or status and has manifestations in affective and ontological area of an individual, behaviour, strategies of life choice of an individual.

The use of the term "statist" rather than "state" identification emphasizes that it is studied the process of citizen's identification not with the government apparatus or authorities but with nation-building as a socioeconomic, political and socio-cultural community of people formed within a certain territory as a result of the interaction of different communities (national, ethnic, denominational, etc.).

The concept of statist identity draws attention to the very political not legal or sociological aspects of the process of social consolidation on a limited number of values shared by all inhabitants regardless of the kind of civic community they belong to.

Comparing the concepts "statist identity" and "national identity", it worth noting the use of the former directly indicates the political and legal nature of the phenomenon under consideration. At the same time, the category "national identity" doesn't have a clear content without additional explanation which national features it means - ethnic or political.

${ }^{16}$ Пашина Н. П. Державницька ідентичність. Політична лексика сучасного украӥнського політика і громадянина: енциклопедичний словник-довідник. Львів: «Магнолія 2006», 2017. C. 110. 
In our opinion, the very concept "statist identity" corresponds to the concept of territorial patriotism, which was introduced by the prominent Ukrainian thinker V. Lypynskyi, to a greater extent. In his analysis, territorial patriotism should unite Ukrainian society and overcome the internal weaknesses of Ukrainian society. V. Lypynskyi considered the territorial patriotism as the awakening of a sense of solidarity and unity of all the permanent inhabitants of the Ukrainian land regardless of their ethnic origin, class, religion, socio-cultural level. That is why the love of the country - the Ukrainian land - which feeds all its inhabitants is an objective prerequisite for the creation of a social-national union. Thus, according to V. Lypynskyi, patriotism means the consciousness of the territory, the love of the land, of all its inhabitants without exception ${ }^{17}$. Condemning nationalism, the scholar empathized that it is based on the consciousness of the community, not the territory, the sense of unanimity of people of one faith and one state, albeit from different territories, and hatred of people of another faith and another condition in any territory.

V. Lypynskyi's conclusions are of the most immediate interest in the $\mathrm{XXI}$ century, as the task of transition from retrospective-destructive to perspective-constructive comprehension of the Ukrainian statehood and relevant civil identification has not been completed. The point at issue is the fact that Ukrainian identity is often interpreted as a factor which divides ethnic Ukrainians from all other representatives of the Ukrainian society. To conserve and reproduce that sort of division, many political actors inside and outside the county have made efforts.

Instead, perspective-constructive identity needs the mechanisms of natural integration of people with other ethnic background and cultural tradition to Ukrainian cultural-political statecraft space. Moreover, the nationality should be deemed not as a heritage of the past but as the statepolitical project, which is formed and performed with the direct participation of the overwhelming majority of citizens and therefore, creates non-biased opportunities for overcoming mutual claims and mistrust.

The prerequisite for successful democratic development is a positive statist identification of citizens - an awareness of the state unity as an essential value and an integral feature of existence. Active life stance, interaction with other members of the society characterizes the positive statist identification. In modern Ukraine, the formation of the positive statist identity of citizens is hampered by the low level of legitimacy of the authorities and the dominance of paternalistic expectations about the actions of the state. Socio-political stances are marked by distrust and dissatisfaction with the current norms of social and political life under the willing to act against the rules (system

17 Липинський В. До українських хліборобів. Українська суспільно-політична думка у 20-му столітті. Документи і матеріали. Том. І. Київ : Сучасність, 1983. С. 472-483. 
corruption, abuse of authority, tax evasion, etc.). Such development parameters form the confrontation consciousness towards other citizens of the state, which are outside the narrow area of private interests of a person, and provoke deepening of the rifts in Ukrainian society.

The overcoming of such negative processes requires a purpose-oriented program of action, which includes the following components:

- political-legal and value consolidation of society. Statist identity is connected with a range of social values and rules, which an individual accepts and supports as own ones. An effect of the value-based and statutory consensus, which is achieved within an identity, ensures the stability of public relations and gives a sense of safety every member of the society.

- collective self-determination. A community united by shared views is prone to collective thinking and collective actions. Statist identification lays the groundwork for the accomplishment of collective goals and interests. Thus, a life of every member of the community gains an additional sense because such interests and goals become his own to a certain extent. As a result, it is established the prerequisites for the consolidation of activistsbased type of political culture in the society.

- legitimation of authority. Being organized around national identity, the community is naturally structured distinguishing its executive core a group that is empowered to make decisions and to promote the interests of the community. The function of government in that kind of a society is inherent in the processes of delegating powers and political responsibility. Shared identity is an intermediate conceptual structure in the relationship of trust between the people and the authorities.

- international actorness. The identification of the individual with the whole statist unit is a prerequisite for an effective foreign policy of the community. In international relations, the nation acts as a consolidated entity that must clearly understand its interests, make its strategy, make well-timed and unmistakable political decisions, and preserve the coherence and continuity of the foreign policy course regardless of changes in the foreignpolicy state of affairs. A high level of coherence and coordination is achieved through complex collective forms of the national consciousness, which are traditionally peculiar to the state political elite of developed countries, and due to the comprehension and support of national goals by the majority of the population.

- image promotion and support. Based on the specific forms of the national awareness (history, culture, special aspect of the national character, lifestyle), it is build the general image of a representative of that sort of society. This image makes an impact on the interaction of each member of the community with the external world giving it certain benefits or damaging its reputation depending on the specific situation. As globalization and 
communication technologies are swiftly expanding international contacts, the credibility of a particular nationality or the prejudiced attitude to its representative is a major factor in life and activity for an increasing number of people ${ }^{18}$.

Keeping in mind the above, one can conclude that in the concept of political identification, the statist component becomes central for modern Ukraine. The very statist identification of citizens should be a particular filter which forms the public perception (support or rejection) of the authorities, political leaders, ideologies, parties and other political entities. The process of shaping political identity has a dual nature: on the one hand, it involves a set of actions of the state policy, which are aimed at consolidating the society, and on the other hand - the activities of civil society, its reaction to the authoritative influence, acceptance or denial of elite policies.

The building of that kind of civic culture, the core of which is statist identification, can secure public consensus on the prospects and criteria for the development, cutback of conflict nature of the political environment and stable progress of Ukrainian society. Statist identification is the most relevant to the development of Ukraine in the XXI century because the democratic transformations are impossible without the growth of social capital of the community through advancing self-organization based on the confidence and interaction of different social groups and segment of the society.

Party identity can't act as an efficient core of the political identification of citizens in modern Ukraine as it took place in the classical democracy countries in the XX century because:

first, the country makes massive socio-political transformations, and their success is directly dependent on the unification of society around a particular value system, which is supported by all the leading political forces;

second, modern political parties have largely lost the ideological component and become the technological means of mobilizing of votes during election campaigns. This has caused the decline in popularity of parties and the blurring as well as the uncertainty of their public support. Thus, the identification with a party can't today guarantee the necessary consensus of the society following statist values and goals of social and political development;

third, nowadays, political identity is gaining new meaning, distancing itself from traditional political and party ideologies as rigid one-dimensional political models significantly discredited themselves in the context of democratic transit at the turn of the twentieth and twenty-first centuries.

${ }^{18}$ Україна: політичні стратегії модернізації : зб. науково-аналітичних доп. / за ред. М. М. Розумного (заг. ред.), О. А. Корнієвського, В. М. Яблонського, С. О. Янішевського. Київ : НІСД, 2011. С. 9-10. 


\section{CONCLUSIONS}

The formation of constructive macro-political identity contributes to the stability of the political system and is a factor for stable development of society. New realities of the modernity, which are related to globalization processes and growth of migration, blur the state borders and complicate the fragmentary nature of society and identification benchmarks. The state is tasked with developing new models of identity politics which would adequately reflect the current dynamics of public consciousness and the segmentation of plural societies. Macro-political identity in plural societies is an important resource for the stabilization of society because it guarantees the public consensus towards the central problems over socio-cultural, political and other disputes. It is a factor that concretes plural societies, sociocultural basis that provides for the sustainability of the whole social system, an important component of the entire national security.

Thus, the task of the modern postmodern states is the constructing of such a universal model of political identity which would consolidate the society based on the norms and values, which are accepted by all members of the society, and be a ground for the collective self-identification of the national community. At the same time, the main mechanism for the formation of any collective model of identity is the reliance on cultural-civilizational and social priorities and practices existing in society.

The interest of Ukrainian scholars in the problems of macro-political identity is conditioned by the fact that politization of regional differences has led to the intensification of regionalization of electoral political preferences, escalation of social controversies concerning the geopolitical and ethnocultural values.

The key target of identity politics in the modern Ukraine is the shaping of that kind of macro-political identity which would be manifested not only in the collective positioning in relation to other nation-states as a basis for the integrity of the nation but also as a subject of the consensus on the community's vision of public goals and values. In this very context, political identity acts both as a frame and factor for stabilizing society.

Consolidated macro-political identity in contemporary Ukrainian society must have civic content and interpretation and be a democratic basis for the unification of many identities present in Ukrainian society. "Statist identity" based on democratic values and "statist patriotism" is a public identity which takes into account public socio-cultural and political realities of Ukraine.

Statist model of identity requires the mechanisms of public integration of people, their unification towards the realization of cohesion of statepolitical and cultural-valuable space. 
Consequently, the modern Ukrainian state has to purposefully shape common identification of citizens through internal and external policy. The problems of formation of agreed development benchmarks of the country, their foregrounding and aggregation within a political course are currently main concerns of public policy.

\section{SUMMARY}

The article studies the interrelation of constructive macro-political identity with stable development of the society. It shows that when motivating political behaviour, political identity, especially in its collective macro-forms, determines a direction and is the most important resource of political development, guarantees the stability of the political regime and political system. And vice versa, the lack of collective forms of the political level at the macro-level sharpens political contradictions in plural societies and is a trigger for political turmoil and separatist tendencies.

The role and significance of macro-political identity for the sustainable development of society are determined by its functions which it performs in the state. First of all, this is an integration and consolidation of the citizens of the segmented community (state, supra-state) on the ground of generally accepted goals and values. Agreement about the key strategic issues provides for the consistency of socio-political conduct and its modeling in the direction favorable for the country.

The objective of identity politics in modern Ukraine is the building of that kind of the model of macro-political identity which would secure a public consensus on the major challenges for the development over socio-cultural, political and other contradictions and be a cementing factor, socio-cultural basis that arranges stability of the whole social system.

Consolidated macro-political identity in contemporary Ukrainian society must have civic content and interpretation and be a democratic basis for the unification of many identities present in Ukrainian society. "Statist identity" based on democratic values and "statist patriotism" is a public identity which takes into account public socio-cultural and political realities of Ukraine. Statist model of identity requires the mechanisms of civic integration of people, their unification towards the awareness of the unity of the statepolitical and cultural-value space. 


\section{REFERENCES}

1. Гудков Л. Н. К проблеме негативной идентификации. Гудков Л. Н. Негативная идентичность: статьи 1997-2002 годов. Москва : Новое литературное обозрение, «ВЦИОМ-А», 2004. С. 262-299.

2. Инглхарт Р. Модернизация, культурные изменения и демократия: Последовательность человеческого развития. Москва : Новое издательство, 2011. 464 с.

3. Ідентичність громадян України в нових умовах: стан, тендерції, регіональні особливості. Український центр економічних і політичних досліджень імені Олександра Разумкова. 2016. № 3-4 (161-162). URL: http://razumkov.org.ua/uploads/journal/ukr/NSD161-162_2016_ukr.pdf.

4. Лейпхарт А. Демократия в многосоставных обществах: сравнительное исследование. Москва : Аспект-пресс, 1997. 288 с.

5. Липинський В. До українських хліборобів. Українська суспільно-політична думка у 20-му столітті. Документи і матеріали. Том I. К. : Сучасність, 1983. С. 472-483.

6. Маслоу А. Мотивация и личность. Санкт-Петербург : Евразия, 1999. $478 \mathrm{c}$.

7. Ноэль-Нойман Э. Общественное мнение : открытие спирали молчания. Москва: Прогресс-Академия, Весь Мир, 1996. С. 74-95.

8. Основні засади та шляхи формування спільної ідентичності громадян України. Український центр економічних i політичних досліджень імені Олександра Разумкова. 2017. № 1-2 (169-170). URL: http://razumkov.org.ua/uploads/journal/ukr/NSD169-170_2017_ukr.pdf.

9. Панчук М. Етнополітичні процеси в Україні: регіональні особливості. К.: Інститут політичних і етнонаціональнихдосліджень ім. І.Ф. Кураса НАН України, 2011.396 с.

10. Пашина Н. П. Державницька ідентичність. Політична лексика сучасного українського політика i громадянина: енциклопедичний словник-довідник. Львів: «Магнолія 2006», 2017. 438 с.

11. Пашина Н. Концепт політичної ідентичності в українській політичній науці. Політичний менеджмент. 2012. № 4-5. С. 180-191.

12. Пашина Н. П. Політика ідентичності: сутність та функції формування. Науковий часопис НПУ імені М. П. Драгоманова. Серія 22 : Політичні науки та методика викладання сочіально-політичних дисииплін. 2015. Вип. 17. С. 88-93.

13. Угрин Л. Я. Ідентичність і безпека: проблеми співвідношення в контексті сочіального конструктивізму. Гілея: науковий вісник. 2016. Вип. 111. С. 329-333.

14. Україна: політичні стратегії модернізації : зб. науково-аналітичних доп. / за ред. М. М. Розумного (заг. ред.), О. А. Корнієвського, В. М. Яблонського, С. О. Янішевського. К. : НІСД, 2011.328 с. 
15. Україна: шлях до консолідації суспільства: національна доповідь. Інститут політичних і етнонаціональних досліджень ім. І. Ф. Кураса НАН України. Київ : НАН України, 2017. 336 с.

16. Bauman Z. Identity. Cambridge : Malden, 2004. P. 12-13.

17. Lehmbruch G. Segmented Pluralism and Political Strategies in Continental Europe: Internal and External Conditions of "Concordant Democracy». Paper presented at the Round Table of the International Political Science Association, Turin. 1969. September. P. 1-2.

\section{Information about the author:} Pashyna N. P., Doctor of Political Sciences, Associate Professor, Professor at the Department of International Relations and Foreign Policy, Mariupol State University 129a, Budivelnykiv ave., Mariupol, 87500, Ukraine 


\section{METHODOLOGICAL FOUNDATIONS FOR MODELING CONTEMPORARY POLITICAL ACTIVISM IN THE DIGITAL AGE}

\section{Polovyi M. A.}

\section{INTRODUCTION}

Various forms of political activism are becoming more widespread at the modern stage of political development. Detailed research of the manifestations of modern activism, obviously, should include, in addition to their description and explanation, a certain prediction as to the emergence and degree of impact of different forms of activism. In this regard, the methods of mathematical modeling of political processes get special importance, as they form the basis for scientific comprehension of certain processes and for making predictions about these processes. Therefore, the purpose of this paper is to define and analyze some methodological foundations which can lay the basis for modeling of such a contemporary form of political processes as political activism.

\section{Theoretical underpinnings of models' application in the studies of socio-political processes}

The positive aspects of building models with research purposes are well known ${ }^{1}$. Yu. Plotinsky studied in detail, but mainly in the sociological frameworks, the application of different models in relation to social processes ${ }^{2}$. At the same time, there are many theoretical and methodological problems of construction and further application of such models in political studies.

Among the many definitions of the term model, scientific literature has two most common:

- model as an analogue of an object;

- model as a sample ${ }^{3}$.

In our definition of the model, we proceed from a rather traditional scientific understanding of the model as an artificially created object in the form of a scheme, logical and mathematical formulas, in a certain sense

${ }^{1}$ Павловский Ю. Н. Имитационное моделирование. М. : Издательский центр «Академия», 2008 - 240 с.; Моисеев Н.Н. Математика в социальных науках // Математические методы в социологическом исследовании. М., 1981. C.10-24; Easton D. A Systems Analysis of Political Life. New York: Wiley, 1965.

${ }^{2}$ Плотинский Ю.М. Модели социальных процессов : 2-е изд., перераб. и доп. М.: Логос, 2001. 296 с.

${ }^{3}$ Ibid. C. 3. 
similar to the studied object and clearly reflecting its individual features ${ }^{4}$. Therefore, in our opinion, the model of the political process can be defined as an artificially created object in the form of various symbolic constructions, which is similar to the studied process in a certain sense. The task of the model constructing is its research and thus deepening the knowledge about modeled features of the original object.

So, the epistemological essence of constructing the model is a transition from a direct study of the initial phenomenon, process, or technical system to another phenomenon, process, or sign system called model. This transition, in some cases, gives the only possibility to reproduce studied phenomena, facilitates research, makes it fundamentally possible to determine values, processes, and their properties interesting to the researcher.

Thus, the model coarsens, simplifies the original, roughly reflects the studied object but, at the same time, serves as its substitute for the study and, in addition, allows to clearly see individual sides (features) of the original ${ }^{5}$.

However, two conditions must be met: on the one hand, the model must be simple enough to be studied; on the other hand, the model should not be "too simple" or overly simplified. Although the model is in some sense "imperfect" and "rough" compared to the studied phenomenon, one model can be used to describe a wide class of different phenomena.

It should be noted that depending on the tasks of the study different models may be obtained for the same object with the aim to formalize its different functions. The number of these models often depends on the complexity, specification or simplification of the description of the real system ${ }^{6}$. Obviously, the suchlike approach is directly linked with the basic property of reflecting only some features of the original object.

While identifying methodological content needed for the construction of models of political processes, one should also consider the problem of correlation between the model and the theory. According to V. Shtoff, starting from the eighteenth century the model has been considered by scientists as something profoundly different from theory. The theory in this sense means a set of statements about the general laws of a particular field, linked logically together so that certain consequences derive from the original assumptions; then the model is understood as either a) a specific image of the studied object or objects (atom, galaxy, etc.), which reflects its real or predicted properties, structure, and other features of these objects; or b) any other object actually 1988. $506 \mathrm{c}$.

${ }^{4}$ Вартофский М. Модели. Репрезентация и научное понимание. М.: Прогресс,

${ }^{5}$ Кондаков Н.И. Логический словарь-справочник / Отв. ред. Д.П. Горский. М.: Наука, 1975. С. 361.

6 Пащенко Ф.Ф. Введение в состоятельные методы моделирования систем : в 2-х ч. М.: Финансы и статистика, 2006. Ч.1: Математические основы моделирования систем. 328 с. 
existing (or imagined) along with a studied object and similar to it in terms of certain properties or structural features. But no matter how different these two meanings are, they have a common understanding of the model as a certain finite system, a certain unitary object, without distinction whether it exists in reality or only in the imagination. In this sense, the model is not a theory itself but something described by this theory - its unique subject ${ }^{7}$.

Yu. Plotinsky slightly broadens the understanding of the interrelationship between the model and the theory. He rightly pointed out that the concepts of the "model" and the "theory" are interpreted ambiguously by modern scientific literature, the line between them is blurred. At the same time, Yu. Plotinsky stated that the methodology of science recognizes the following interpretation of these concepts:

- The model is a conceptual tool primarily focused on managing a simulated process or phenomenon. Thus the function of prediction and prognostication serves to the purpose of control.

- The theory is more abstract than the model, a conceptual tool whose main purpose is to explain these processes and phenomena. The predictive function of the theory is aimed to explain phenomena ${ }^{8}$.

V. Shtoff thought that an essential feature that in general distinguishes the model from the theory is "not the level of simplification, not the measure of abstractedness and, therefore, not the number of abstractions and distractions achieved, but the way in which these abstractions, simplifications and distractions are typical for the model"9. While the content of the theory is expressed in the form of a set of judgments, linked by the laws of logic and special scientific laws and "directly" reflecting regular, necessary and general connections and relations inherent to reality; the same content in the model is presented in the form of certain typical situations, structures, schemes, collections of idealized (even simplified) objects, in which these regular connections and relations are realized, or in which laws formulated by the theory are implemented in its pure form. Therefore, the model is always a particular concrete construction: visual, finite and accessible for inspection or practical action.

Therefore, if the property to reflect reality (object) in a simplified, abstracted form is common for the theory and the model, the property to implement this reflection in the form of a particular, separate, concrete and, therefore, visual system - is a feature which distinguishes the model from the theory ${ }^{10}$.

\footnotetext{
${ }^{7}$ Штофф В.А. Моделирование и философия. Л.: Наука, 1966. С. 9.

${ }^{8}$ Плотинский Ю.М. Модели социальных процессов. М.: Логос, 2001. С. 87.

${ }^{9}$ Штофф В.А. Моделирование и философия. Л.: Наука, 1966. С. 14.

${ }^{10}$ Ibid. C. $14-15$.
} 
As L. Boiko-Boichuk correctly points out, introducing the methods of modeling from the natural sciences into political science has become possible precisely due to the analogy ${ }^{11}$. According to A. Uyemov, for the first time, the term "analogy" appeared in the Pythagorean school, where it was originally used only for the study of relations between numbers in the meaning of proportionality, proportion ${ }^{12}$. Aristotle understood the analogy as a similarity of relations, proportion ${ }^{13}$. As it follows from A. Uyemov's fundamental work, in our time proportion is treated only as one of the possible types of analogy.

A. Uyemov defined the analogy as one of the types of inference (along with induction and deduction), in which the conclusion relates to a subject other than the one in the premise ${ }^{14}$. After careful analysis of different examples of the use of analogy in the natural sciences, A. Uyemov identified fifty-one types of inference of new knowledge by analogy, including proportional, substantive, and other analogies ${ }^{15}$.

Obviously, an analogy must be characterized by at least two of the following features: firstly, it must be based on a certain (in some sense) similarity of one object and another - in our case these are the model and its original; and, secondly, the essence of the analogy is in the transferring of certain information or knowledge about the properties of one object to another, the one with which the analogy is drawn.

So, it is precisely the analogy between the object of a study - the political process - and the model that reflects its particular features that enables the use of modeling in the study of political processes. Thus, the conclusions drawn about the further state of the model will be transferred to the further state of the modeled object by analogy.

Analogy, as well as other forms of reasoning - induction and deduction - is inextricably linked to a single thought process. It is closely related to them and cannot exist without continuous mutual complement and interaction with other conclusions. The analogy has some cognitive value. The inference process gives probable knowledge, but this probable knowledge carries something new, which helps us to understand the environment and to predict the development of this phenomenon or event. At the same time, no matter how significant the similarity of two things is, conclusions by analogy are always probable ${ }^{16}$.

${ }^{11}$ Бойко-Бойчук Л. Метод аналогій у соціально-політичних дослідженнях. Політичний менеджмент. 2007. № 4. С. 78-80.

12 Уемов А. И. Аналогия в практике научного исследования. М.: Наука, 1970. С. 50.

${ }^{13}$ Ibid.

${ }^{14}$ Ibid. C. 19.

${ }^{15}$ Ibid. C. 46-63.

${ }^{16}$ Кондаков Н.И. Логический словарь-справочник. Отв. ред. Д.П.Горский.М.: Наука, 1975. С. 38. 
In assessing the probability of inference a number of the following conditions should be taken into account:

1) the more general properties of the comparable objects you know, the higher probability for the conclusion by analogy is;

2) the more significant common properties found in the comparable subjects are, the higher the probability is;

3) the deeper mutual logical relationship of similarities is, the more probable and closer to reliability the conclusion is;

4) if the object in respect to which we make the conclusion by analogy has any property incompatible with the property on the existence of which we conclude, then the general similarity is irrelevant ${ }^{17}$.

A. Uyemov added the following rules to this list: 1) general properties should be any properties of the comparable objects, thus they must be selected "without prejudice" against properties of a certain type; 2) the property detected in the model must be of the same type as the general properties of the studied object; 3) the general properties should be as specific as possible for the comparable objects, that is, they should belong to the smallest possible range of objects; 4) the property found in the model, on the contrary, should be the least specific, that is, belong to as many objects as possible ${ }^{18}$.

A. Uyemov also noted that there are characteristics common to all types of conclusions by analogy. In particular, in all cases, one subject is put to direct investigation, while the conclusion is drawn in relation to another subject. Therefore, the conclusion by analogy, in the most general sense, is the transfer of information from one object to another. "The object, which is the direct object of the study is called the model, and the object, to which the information acquired as a result of the study is transferred, is a sample, original, prototype, etc". On this basis, analogy is defined as the relation between any model and its original prototype; the analogy is the conclusion from the model to the original ${ }^{19}$.

C. Hempel claimed that models whose elements and relationships are connected to the world by what is commonly called compliance rules, should include the following three types of compliance:

- between the way the social world is organized and the way the model describes this world;

- between the apparatus used in the modeling and the conceptual apparatus of the modeled theory;

- between the theory and the social world ${ }^{20}$.

${ }^{17}$ Ibid. C. 38.

${ }^{18}$ Уемов А. И. Аналогия в практике научного исследования. М.: Наука, 1970.

${ }^{19}$ Ibid.

${ }^{20}$ Гемпель К. Г. Логика объяснения. М.: Дом интеллектуальной книги, Русское феноменологическое общество, 1998. С. 56-57. 
Accordingly, we see that modeling is a broader concept that includes conclusions by analogy as its integral part. The analogy implies the correlation between the model already given in one way or another and its (prototype), and the result of the model's study, in this case, is assumed to be known. The concept of the method of modeling includes the construction of the model or finding it in nature. An important stage in the application of the modeling method is the study of the constructed model, obtaining with it all the necessary information and, finally, the transfer of conclusions made towards the model to the original.

During the construction, the study of the model and the transfer of conclusions obtained from the model to its original, the researcher relies on the analogy procedures described above and proceeds with the conformity of the model to the modeled object. Usually, objects fully or partially equivalent to the original in relations interested to the researcher are used as models. In the first case, we are talking about isomorphic models, in the second case homomorphic. Isomorphic models with respect to the original must be endowed with the properties of reflexivity, symmetry, and transitivity ${ }^{21}$. For homomorphic models, symmetry property is not required. Most mathematical models are based not on isomorphism but on homomorphism with respect to the original ${ }^{22}$. "Homomorphism is a kind of systematic abbreviated translation. The original is not only translated into another language but is also abbreviated. What eventually comes out after translation and abbreviation turn out to be systematically evenly compressed in half or one third, or some other proportion of the original. Some details of this abbreviation may be lost, but everything in the original is somehow translated, scaled-down and saved" ${ }^{23}$. In the case of a homomorphic reflection, the purpose of modeling is to implement one or another way for the reflection of state space (parameters or properties) of the studied object onto another space, similar to it. Obviously, the processes of simplifying the original within the limits allowed by conditions of the study have general nature.

From the above interpretation of the model, it is obvious that for the vast majority of political processes only homomorphic models are possible.

${ }^{21}$ Кондаков Н.И. Логический словарь-справочник. Отв. ред. Д.П. Горский. М.: Наука, 1975. С. 191.

22 Ibid. C. 123.

23 Прангишвили И.В. Системные законы и закономерности в электродинамике, природе и обществе. М.: Наука, 2001. 


\section{Assessment of the applicability of different types of models for modeling contemporary political activism}

According to F. Pashchenko, in the framework of the extensive system of modeling methods that exist today, great importance belongs to analytical, experimental and combined methods ${ }^{24}$.

The analytical method implies the imaginary penetration "inside" the object. In this case, the properties of the object, its mathematical description and interrelationships of elements are established by a comprehensive analysis of the phenomena and processes occurring in it, on the basis of known political, economic and social laws and patterns. The undoubted advantage of the analytical method is that it does not require direct contact between the researcher and the object. This means that when using this method, the modeled socio-political structure and corresponding infrastructure may not exist at all. Thus, when using this method on the basis of socio-political description, analytically mathematical model may be built of such a political process, which has certain attributes that interest the researcher, even if it was not yet built in real life. The building of the suchlike model opens up the broadest possibilities for analyzing the various possible situations and ways of development that may take place in the future of a real political process under certain initial conditions.

Determined analytical models are useful as a tool for mathematical experiments aimed at developing a strategy for more detailed cognition of the political process and its subsequent management. Calculations with the use of deterministic, deductive models may be very productive as they replace practically impossible field experiments. At the same time, it should be acknowledged that such models cannot be used for daily monitoring or for a detailed forecast of the real dynamics of political development. This is explained by the need for a clear parameterization of such models, without which they are transformed into beautiful but useless metaphors. Despite the indicated advantages of the analytical method, it should be noted that the extensive experience of modeling complex natural objects, accumulated in various fields of science, shows that, despite its attractiveness, it can have only limited use ${ }^{25}$.

Limited use of the analytical method is associated with its complexity and the need to know the laws and patterns of internal processes of the studied system. Mainly, this requirement may be fulfilled in the frameworks of natural sciences, and therefore can justify itself in the study of the political process only when building cognitive models of a general nature. When studying modern political activism, we are faced not only with the problem of an

${ }^{24}$ Пащенко Ф.Ф. Введение в состоятельные методы моделирования систем : в 2-х ч. М.: Финансы и статистика, 2006. Ч. 1: Математические основы моделирования систем.

${ }^{25}$ Малинецкий Г. Г. Современные проблемы нелинейной динамики. М.: УРСС, 2002. 
insufficient study of the subject but also with the problem of the constant variability of forms and methods of political activism. Moreover, the digital capabilities of the modern era give it additional features and modifications.

Experimental studies are based on obtaining the dependencies by measuring corresponding values directly on the studied object. The essence of the experimental method of modeling implies that in the process of functioning of a real socio-political object the researcher measures the selected parameters and according to the results of observations assesses the properties of the object and make a mathematical description, suitable for the analysis of the state of this object and for the development of optimizing criteria for a given object. The construction of a mathematical model of an object based on experimental studies and measuring of its input and output signals is called object identification ${ }^{26}$. Experimental methods of modeling may be considered more appropriate to describe political activism. At the same time, as in many other cases, it is a difficult problem to determine the degree of impact on society and the political process of some steps made at the actions of political activism.

Combined methods are a combination of analytical and experimental methods for the construction of a mathematical model. If these models are used, the type and structure of the model are selected based on an analytical approach. The structure of the model, in this case, we must take into account the objective laws of the processes occurring in the studied object. Unknown parameters included in the obtained model are determined on the basis of experimental studies. Combined methods usually include expert dynamic and expert analytical methods ${ }^{27}$. The last two approaches are virtually indistinguishable in content and methods. Their main difference unlike these approaches from analytical and experimental is that, in addition to analytical and experimental methods, they use expert knowledge about the system under study - the knowledge of the researcher, expert analyst, deeply familiar with the process being studied or the phenomenon. Such approaches have been widely used in the creation of human-machine systems, decision-making for the management of large-scale systems, industries, regions, nuclear and large thermal power plants, metallurgical, petrochemical and other industries. ${ }^{28}$ There is a double situation in the political sciences, where, on the one hand, there is a long tradition of using expert knowledge, but on the other hand, it is extremely rare that this knowledge is used to build research models.

\footnotetext{
Пресс, 1994

28 Дургарян И.С. Системы поддержки принятия решений в человеко-машинных системах управления. Труды Института проблем управления. 2000. Т. 8.
}

${ }^{26}$ Райбман И.С. Что такое идентификация? М.: Наука, 1970.

${ }^{27}$ Бургин М.С. Введение в современную точную методологию науки. М.: Аспект 
An attempt to combine analytical and expert methods of model construction in the last decades has given rise to the so-called holistic approach to the description of complex systems and models' construction.

A holistic approach implies a global description and is necessary in the case of complex systems where traditional reductionist methods do not allow to fully analyze trends because of an excessively large number of significant variables.

The possibility of a holistic description is associated with the "compression" of information by introducing order parameters. As a rule, holistic models are characterized by "slow" equations that link these parameters to each other. It should be noted that the transition from a reductionist to a holistic approach in the construction of the models means, in fact, a transition from purely deterministic models to phenomenological ones. A bright example of a holistic approach to modeling is, in our opinion, synergetic models.

Synergetics is often associated with the names of H. Haken ${ }^{29}$ and I. Prigogine ${ }^{30}$, and these scholars are called the founders of synergetics, which is quite true. Synergetics is also associated with the names of such scientists as R. Thom, B. Mandelbrot, Yu. Klimontovich, S. Kurdyumov, G. Malynetsky, D. Chernavsky, and others. The term, which has become popular, is being used in the most unexpected and paradoxical contexts: the synergetic paradigm, the synergetic approach to national security, the synergetic beginnings of education, etc.

H. Haken gave one of the first definitions of the subject of synergetics. According to him, synergetics studies systems consisting of a large number of parts, components or subsystems, in a word, of details that interact in a complex way. The word "synergetics" means "joint action", emphasizing the coherence of the functioning of parts, reflected in the behavior of the system as a whole ${ }^{31}$.

Synergetics is interested in the general patterns of evolution of systems of any nature. Abandoning the idea of the specific nature of systems, synergetics find the ability to describe their evolution in an international language, establishing a kind of isomorphism of two phenomena studied by specific means of two different sciences, but having a common model, or, more precisely, being reduced to a common model. Discovering the unity of the model allows synergetics to make advantages of one scientific field accessible to the representatives of another field and transfer the results of one science to the seemingly extraneous environment ${ }^{32}$.

${ }^{29}$ Хакен Г. Тайны природы. Синергетика: учение о взаимодействии. М. : ИКИ, 2003.

${ }^{30}$ Пригожин И. Р. Порядок из хаоса: Новый диалог человека с природой : Пер. с англ. М. : Прогресс, 1986.

${ }^{31}$ Хакен Г. Тайны природы. Синергетика: учение о взаимодействии. М. : ИКИ, 2003.

32 Данилов Ю.А. Роль и место синергетики в современной науке. URL: http://www.synergetic.ru/science/rol-i-mesto-sinergetiki-v-sovremennoy-nauke.html. 
So, according to one of its creators, H. Haken, synergetics is designed to play the role of a kind of meta-science that observes and studies the general nature of those laws and dependencies that some sciences consider "their own". The closest to it in terms of proclaimed tasks is the direction of the study of the general theories of systems, popular in the 50's - 70's of the last century ${ }^{33}$. Unlike the "standard" system approach, synergetics offers a different approach to selecting information about a particular process for analysis and modeling. Instead of a large number of factors (the so-called components of the state vector), on which the state of the system depends on during ordinary finitedifference modeling ${ }^{34}$, synergetics considers a few order parameters on which the components of the state vector of the system depend and which, in turn, influence the order parameters. The transition from the components of the state vector to the few order parameters is the meaning of one of the basic principles of synergetics, the so-called principle of subordination.

The distribution of synergetic concepts as a general scientific paradigm raised the question not only of the expansion of the categorical apparatus of social and humanitarian disciplines but also of the use of some universal mathematical models developed in the framework of the theory of nonlinear dynamic systems and the mathematical theory of chaos. As already mentioned, synergetics proceeds from the fact that, in reality, the "linear nature of the development of processes" and "equilibrium states" are not always dominant.

The complexity and unpredictability of the behavior of systems during periods of their unstable development - bifurcation points - deserves much more attention. The manifestations of such points are quite diverse the destruction of states, external interventions, coups, large-scale terrorist acts, wars, financial and other crises, forced reforms, stalemate electoral situations, revolutions, powerful protest reactions of society. It is in these circumstances that "minor" causes can have a decisive influence on the trajectory of political and international processes.

An important quality of synergetic modeling, which makes it capable of answering questions about the essence of the bifurcation of the domestic political process, can be considered the possibility of establishing the likelihood of chaotic regimes in a long process, including those that will arise "without any noticeable" external reasons, and simply because of the nonlinear process development ${ }^{35}$. In fact, in today's scientific work, the study of political phenomena and processes is dominated by the notion that every single point of bifurcation and the nearest determinative stage of development

\footnotetext{
33 Уемов А.И. Системный подход и общая теория систем. М. : Наука, 1978.

${ }^{34}$ Павловский Ю. Н. Имитационное моделирование. 2-е изд., стер. М. : Издательский центр «Академия», 2008.

35 Див., напр.: Бородкин Л.И. Бифуркации в процессах эволюции природы и общества: общее и особенное в оценке И. Пригожина. Информационный бюллетень Ассоичиации «История и комп ’ютер». 2002. № 29. С. 5-19.
} 
of a large socio-political unit like a state is best matched by a certain parameter of $\operatorname{order}^{36}$. At the same time, there is no unity in the scientific environment as to the method of the most adequate description of the given bifurcation, of the world, and the bifurcations of individual countries under the conditions of this "global" bifurcation (of course within the synergetics, in which, however, many separate directions have appeared), and relatively order parameters for the current bifurcation situation.

The chaos that occurs near the bifurcation point does not mean that the order disappears. Rather, the dynamics of the process become internally unpredictable (not through external factors). The central issue discussed in this connection is the mechanisms of choice of alternatives to social development, the influence of chance, which in bifurcation points are fundamentally impossible to predict and predict in a deterministic sense. It is from this point of view that synergetic modeling is a promising tool for building models of modern activism. At the same time, these models will have a somewhat unusual character: it is recognized that if the sources allow reconstructing the patterns of long-term development of the process, using computerized methods can determine the likelihood of chaotic modes, including those that occur "without any noticeable "external reasons, but simply because of the non-linear process development ${ }^{37}$. Accordingly, when constructing a model of political activism by a synergetic method, it is said that the researcher should parameterize the model not so much by "unique" material of individual political actions, but by aggregated formalized data on the general dynamics of such actions - their number at certain intervals, the number of participants in saturation of flights. and non-political slogans and requirements, the degree of coverage of these actions by the media, etc.

At the same time, the experience of synergetic modeling makes it possible to prove that even at bifurcation points "anything" cannot happen. The number of real-world scenarios is always limited, and if events have already entered one of the modes (trajectories), the system irrevocably changes in the direction of the corresponding end state (attractor) ${ }^{38}$.

A successful example of the synergetic model of political activism is the modified J. Davies' model of J-revolutions, a model of sudden formation of political resistance ${ }^{39}$. The main parameter of order in this model based

${ }^{36}$ Халтурина Д.А. Системный мониторинг: Глобальное и региональное развитие. М.: УРСС, 2010. С. 5.

${ }_{37}^{37}$ Див., напр.: Бородкин Л.И. Бифуркации в процессах эволюции природы и общества: общее и особенное в оценке И. Пригожина. Информационный бюллетень Ассочиачии «История и комп 'ютер». 2002. № 29. С. 5-19.

${ }^{38}$ Назаретян А.П. От будущего - $к$ прошлому (Размышление о методе). Общественные науки и современность. 2000. № 3. С. 148.

${ }^{39}$ Polovyi M. A., Gadzhyieva D. Synergetic modification of J. Davies' model for simulation of "sudden" formation of protest activity. Athenaeum. 2015. Vol. 48. P. 76-89. 
on the assumption about decisive role of worldview and perception of politics by individual and public opinion ${ }^{40}$. Such an interpretation in some way supports the theory of J. Davies. But it seems right to assume that in order to form a political protest activity a stimulating and unifying factor for a diverse population should become public perception of political reality and their own expectations from it. A synergetic order parameter that determines the formation, expansion or, conversely, narrowing, of protest activity in modern political process is the ratio between the perception of current political reality and tactical expectations from it. The dynamics of this order parameter determines the content of protest activity's model we've created ${ }^{41}$.

\section{CONCLUSIONS}

Thus, with the increasing spread of various forms of political activism, its modeling becomes important. Models of political activism should serve to the purposes of short- and medium-term forecasting of the events related to activism.

In theoretical terms, the model of the political process should be understood as an artificially created object in the form of various symbolic constructions, which in some sense is analogous to the studied process. The task of creating a model is its research in order to deepen the knowledge about modeled features of the original object.

To reflect and predict the future state of any element of the political process, different models can be constructed to formalize its various functions. The number of these models often depends on the complexity, specification or simplification of the description of the real system.

There is a variety of methods of model construction, they include analytical, experimental and combined methods. Combined methods are most suitable for modeling of political activism. The combined methods include expert-dynamic and expert-analytical methods. A holistic approach to the modeling of complex systems is closely linked to these methods. Synergetic modeling is a scientific continuation and a formal extension of the holistic approach.

Synergetics offers an almost holistic approach to the selection of information about modeled process: instead of a large number of factors that determine the state of the system in the ordinary simulation, as finitedifference for example, synergetics considers the few order parameters on which the components of the state of the system depend and which in turn affect the order parameters.

${ }^{40}$ Польовий М. А. Політичні процеси: теорія та практика моделювання. Фенікс: Одеса. 2011. С. 190-217.

41 Polovyi M. A., Gadzhyieva D. Synergetic modification of J. Davies' model for simulation of "sudden" formation of protest activity. Athenaeum. 2015. Vol. 48. P. 76-89. 
The synergetic approach is the most promising in modeling the processes of political activism. In constructing a model of political activism with the use of a synergetic method, the researcher must parameterize the model not so much with the "unique" material of particular political actions as with aggregated formalized data on the overall dynamics of such actions.

The model of sudden formation of political resistance - J. Davies' model of J-revolutions modified by the author- is an example of the synergetic model of political activism. It is obvious that synergetic models of political activism are the most optimal and, at the same time, they need further improvement.

\section{SUMMARY}

The article deals with some methodical problems of selection of appropriate modeling techniques for simulation of contemporary forms of political activism in the digital age. The meaning of model and simulation, their connection with the theory, analogy and metaphor have been analyzed. The possibilities for application of homomorphic models have been evaluated. It has been concluded that the vast majority of political processes may be simulated only by homomorphic models. A short overview of the strengths and weaknesses of analytical, experimental and combined methods of building models has been done. It has been established that an attempt of combining analytical and expert methods of building models in recent decades has generated a so-called holistic approach to the description of complex systems. The characteristic of holistic approach has been given. The continuation of the holistic approach in the form of a synergetic approach has been characterized. It has been noted that the synergetic approach involves a global description and is necessary in case of complex systems, where traditional reduction methods do not allow to analyze trends due to an excessively large number of significant variables. Therefore, the synergetic approach is most convenient for the simulation of processes of political activism. 


\section{REFERENCES}

1. Павловский Ю.Н., Белотелов Н.В., Бродский Ю.И. Имитационное моделирование. М. : Издательский центр «Академия», 2008 - 240 с.

2. Моисеев Н.Н. Математика в социальных науках. Математические методы в социологическом исследовании. М., 1981. С. 10-24.

3. Easton D. A Systems Analysis of Political Life. New York: Wiley, 1965.

4. Вартофский М. Модели. Репрезентация и научное понимание. М.: Прогресс, 1988. 506 с.

5. Кондаков Н.И. Логический словарь-справочник / Отв. ред. Д.П. Горский. М.: Наука, 1975. С. 361.

6. Пащенко Ф.Ф. Введение в состоятельные методы моделирования систем : в 2-х ч. М.: Финансы и статистика, 2006. Ч. 1: Математические основы моделирования систем. 328 с.

7. Штофф В.А. Моделирование и философия. Л.: Наука, 1966. C. 9.

8. Бойко-Бойчук Л. Метод аналогій у соціально-політичних дослідженнях. Політичний менеджмент. 2007. № 4. С. 78-80.

9. Уемов А. И. Аналогия в практике научного исследования. М.: Наука, 1970. С. 50.

10. Гемпель К. Г. Логика объяснения. М.: Дом интеллектуальной книги, Русское феноменологическое общество, 1998. С. 56-57.

11. Прангишвили И.В., Пащенко Ф.Ф., Бусыгин Б.П. Системные законы и закономерности в электродинамике, природе и обществе. М.: Наука, 2001.

12. Малинецкий Г. Г., Потапов А.Б. Современные проблемы нелинейной динамики. М.: УРСС, 2002.

13. Райбман И.С. Что такое идентификация? М.: Наука, 1970.

14.Бургин М.С. Введение в современную точную методологию науки. М.: Аспект Пресс, 1994.

15. Дургарян И.С., Пащенко Ф.Ф. Системы поддержки принятия решений в человеко-машинных системах управления. Tруды Института проблем управления. 2000. Т. 8.

16. Хакен Г. Тайны природы. Синергетика: учение о взаимодействии. М. : ИКИ, 2003.

17. Пригожин И. Р., Стенгерс И. Порядок из хаоса: Новый диалог человека с природой : Пер. с англ. М. : Прогресс, 1986.

18. Данилов Ю.А. Роль и место синергетики в современной науке. URL: $\quad$ http://www.synergetic.ru/science/rol-i-mesto-sinergetiki-vsovremennoy-nauke.html.

19. Уемов А.И. Системный подход и общая теория систем. М. : Наука, 1978. 
20. Бородкин Л.И. Бифуркации в процессах эволюции природы и общества: общее и особенное в оценке И. Пригожина. Информационный бюллетень Ассочииаџии «История и комп'ютер». 2002. № 29. С. 5-19.

21. Халтурина Д.А. Системный мониторинг: Глобальное и региональное развитие. М.: УРСС, 2010. С. 5.

22. Назаретян А.П. От будущего - к прошлому (Размышление о методе). Общественные науки и современность. 2000. № 3. С. 148.

23. Polovyi M. A., Gadzhyieva D. Synergetic modification of J. Davies' model for simulation of "sudden" formation of protest activity. Athenaeum. 2015. Vol. 48. P. 76-89.

24. Польовий М. А. Політичні процеси: теорія та практика моделювання. Фенікс: Одеса. 2011. С. 190-217.

\section{Information about the author:}

Poloyi M. A.,

Doctor of Political Sciences, Professor at the Department of Political Science and Public Administration, Vasyl' Stus Donetsk National University 21, 600-richcha str., Vinnitsya, 21001, Ukraine 


\section{MULTIVARIATE MEASUREMENT CONCEPT "INFORMATION WAR"}

\section{Pronoza I. I.}

\section{INTRODUCTION}

With the establishment of the information society, and the rule of information technology, the term "information war" not only became symbolic and symbolic unit of journalistic and political vocabulary, but has been actively used as a separate category in the scientific discourse.

Modern XXI century is often called "the era of information technology," which takes place enormous contribution to the development of practices and combat information war, in which information security has become almost a panacea in solving the problems of the information society. The concept of modern information society is equivalent to the concept of "post-industrial society", given the growing political, social and military confrontation states the importance of information and huge investments in research centers. A series of post-industrial countries pay great importance of science, technology and information security of the country, well aware the importance of media influence on public consciousness as the regional and international levels ${ }^{1}$.

Modern domestic and Western scientific understanding of the information wars are far from complete and clarity. In the scientific literature and the Internet launched a great debate about the genesis of information warfare, the nature and means of implementation, methodology, analysis of theoretical, practical and comprehensive information "component" general scientific definition of this phenomenon. It is also very different in some socio-cultural and communication systems, and most importantly, about the subjects and objects of their own information confrontation. A detailed analytics on this topic is not fully available for general purposes and objectives of the study, or suffers frank populism and primarily designed for the mass market. Unfortunately, it must be noted in the scientific heritage.

Scientific work has as its priority partially fill this gap, and the problem is so urgent, serious and sharper than are currently geopolitical order problems are most involved in the structure and values of contemporary information warfare. Since the construction of a multipolar world, which involves creating around the country range of friendly nations that share its goals and values, it is

${ }^{1}$ Проноза I. I. Інформаційна війна: сутність та особливості прояву. Актуальні проблеми політики. Збірник наукових праць. Одеса. 2018.№ 61. С. 121. 
now a priority the idea of political and civil svitobuduvannya, as mentioned studies various forms, methods, tools and techniques of information warfare in the near future will only grow. Geopolitical, civilizational and ethological aspects of information warfare in modern scientific concepts is now the least studied.

\section{Information war: the nature and features of its manifestation}

Mankind at all stages of its establishment, faced with the problem of information warfare at all levels.

Information warfare - a communication technology on the impact of information and information systems of the enemy in order to achieve information superiority in the interests of national strategy, while protecting their own information and information systems. Information warfare - only the means, not the ultimate goal, similar bombardment - a means, not a goal. Information warfare can be used as a tool for strategic attack or counter ${ }^{2}$.

Such researchers as Zinoviev A.A., Dugin A.G., Korovin V.M. say that the new global war already in progress. It is not officially declared and hidden from the eyes of ordinary citizens, but leads humanity to profound changes in the balance of power in the world. The phenomenon described covert war became possible only in the development of modern information and communication technologies. Analysis of international experience shows that direct aggression today is no longer the only means of domination. In this regard modern science gradually focuses on the study of indirect forms of confrontation, focusing on information warfare.

The term "information war" currently has more journalistic in nature and have not received a steady recognition. These are ongoing discussions about what actually lies under this concept, as well as disputes over the accuracy and practical applicability of this term to the sphere of social relations, which is called informational confrontation or conflict of interest in the information sphere of social systems. Thus, a single scientific problem is the development and coordination of research and terminology.

In domestic and foreign science, there are many different and often mutually exclusive approaches to determining the conflicts that occur in modern information space. This diversity and inconsistency is a serious obstacle to the development of the theory of information warfare.

Study the information war is reflected in studies leading analysts from different countries such as Pocheptsov G., Razuvaev V., Tulchin G., Panarin I., Zawadzki J., Rastorguev S. Afanasyev G., Laynbarzhden , Knorih V., Coser L., Lasvel G., Brzezinski Z., Karpenko G., Lipkan V. et al.

${ }^{2}$ Кіслов Д. Сучасні медіа та інформаційні війни : монографія. Київ. міжнар. ун-т, ін-т журналістики. К. : МП Леся, 2013. С. 75. 
For the first time the term "information war" Ron T. taken in the report "weapons systems and information warfare", prepared by him in 1976. He emphasized that the information infrastructure is a key aspect of the US economy, at the same time, it becomes vulnerable purpose as in wartime and in peacetime ${ }^{3}$.

The first used the term "information war" American expert Thomas Rhone report prepared by them in 1976 for the company Boeing, and called "weapons systems and information warfare." Ron T. pointed out that the information infrastructure is a key component of the US economy. At the same time, it becomes vulnerable purpose, as in wartime and in peacetime. This report can be considered the first mention of the term "information war" 4 .

Today the concept of "information warfare" is defined differently. This is due to the ambiguity of the term «information warfare», which has led many discrepancies in his translations. The above concept can be interpreted as "information war", "information confrontation", "informationpsychological war." In particular, the information war is characterized as informational activities used political education (ie the state) to weaken, destroy other political entity; as information by competitors struggle between competitors; Information military conflict between two massive enemies such as armies and so on ${ }^{5}$.

The results of theoretical analysis can be stated that there are many substantiated concepts of information warfare and there is no generally accepted definition of this notion. This variety of approaches is primarily due to the complexity of the object of study and theoretical and methodological position of authors belonging to different scientific schools. This determines the emphasis of their attention on certain aspects of the problem.

Also, as part of a psychological paradigm of the information war is understood as the latent impact of information on individual, group and public consciousness by the methods of propaganda, misinformation and manipulation in order to create new views on social and political organization of society by changing the basic values and attitudes of the individual.

Exploring the information war in the context of psychological theories, V.A. Lysychkin and L.A. Shelepin indicate that its object is cognitiveemotional sphere of individuals, and the main purpose - managing intellectual, psychological and socio-cultural processes that element is mandatory acts

${ }^{3}$ Гриняев С. Концепция ведения информационной войны в некоторых странах мира. URL: http://www.soldiering.ru/psychology/conception_psywar.php

${ }^{4}$ Жарков Я. Інформаційно-психологічне протиборство (еволюція та сучасність) : монографія. Київ. нац. ун-т ім. Т. Шевченка. Київ: Віпол, 2013. С. 15

${ }^{5}$ Манойло А. В. Государственная информационная политика в особых условиях .М. 2013. С. 239. 
of unconscious influence individuals susceptible to influence and veiled following lines programmed behavior ${ }^{6}$

Psychological interpretation of this phenomenon also offer Volkogonov D.A., Zhiveynov N.I. and Karajan A.G. They combine information and psychological confrontation in one concept.

The first two scientists consider the information war as a system subversive ideological influences of imperialism aimed at the minds of people mainly through the field of social psychology ${ }^{7,8}$. In turn, Karajan A.G. adheres to the position that it is about information and psychological actions undertaken at the international or strategic, operational and tactical levels, both in peacetime and in wartime as in information and in the spiritual realm, among its soldiers or enemy ${ }^{9}$.

Ivan Kostyuk ${ }^{10}$ O. Saprykin ${ }^{11}$ P. Shevchuk ${ }^{12}$ researching the information wars, reveal the essence of information processes impact on society.

In turn, Vladimir Karpenko ${ }^{13}$ Ukrainian information space exploring the state covers the expansion of information, which neoimperialistychnyh to spread ideas, takes the form of Russian expansion into Ukraine's information space using their own ends Ukrainian media.

Noteworthy geopolitical approach under the provisions of which, the information war is interpreted in terms of interstate confrontation aimed at solving foreign policy objectives not through physical force, military equipment and weapons, and using sophisticated technologies koyersyvnoho control, which is the outward expression in the form diplomacy.

In modern scientific research singled out the circle of scientists who concentrate on social and communicative aspects of information warfare. Their research methodological principles differ in that the objective was

${ }^{6}$ Лисичкин В. А., Шелепин Л. А. Третья мировая (информационнопсихологическая) война. URL: http://malchish.org/lib/politics/infwar.htm.

${ }^{7}$ Гриняев С. Концепция ведения информационной войны в некоторых странах мира. URL: http://www.soldiering.ru/psychology/conception_psywar.php.

${ }^{8}$ Живейнов Н. И. Операция «РW»: «психологическая война» американских империалистов. М. 1996. 282 с.

${ }^{9}$ Караяни А. Г. Теория и практика психологической войны. Организация и проведение информационных операцій. URL: http://psyfactor.org/lib/psywar30.htm

${ }^{10}$ Костюк I.А. Інформаційні війни в контексті революційних подій в Україні. Актуальні проблеми соціальних комунікацій: матеріали студентської наукової конференції, 22 травня 2014 р. Київ. 2014. С. 57-60.

${ }^{11}$ Саприкін О. Інформаційна експансія, інформаційна війна та інформаційна атака у засобах масової інформації на прикладі Євро-2. Вісник Книжкової палати. 2013. № 1. C. $40-43$.

12 Шевчук П. Інформаційно-психологічна війна Росії проти України: як ій̆ протидіяти. Демократичне врядування. 2014. Вип. 13. URL: http://lvivacademy.com/visnik13/ zmist.html.

${ }^{13}$ Карпенко В. Інформаційний простір як чинник національної безпеки України. Українознавство: науковий громадсько-політичний культурно-мистецький релігійнофілософський педагогічний журнал. 2005. № 3. С. 182-192. 
dominated by information that becomes dominant influence in shaping sms reality and cognitive orientation, not people's minds.

This determination adhere M. Pavlyutenkova ${ }^{14}$ and D. A Swez ${ }^{15}$, by considering the information war is a communication technology which aims to achieve information superiority in the interests of national strategy ${ }^{16}$.

It is of interest to study this problem P. Spyga and R. Rudnik ${ }^{17}$, where scientists identify 4 approaches to the definition of this concept:

- first approach treats them as a set of political and legal, social, economic, psychological operations involving the capture of the information space, ousting the enemy from the information sphere, destroy his communications, deprivation means of communication and other similar purposes;

- the second approach, the information war - is the most severe form of confrontation in cyberspace, where the paramount importance of quality interactions such as uncompromising, high intensity korotkotryvalist sharp disputes and rivalry;

- on the third approach, information warfare is interpreted as a form of providing and maintaining military and security operations by using modern electronic media (digital emitters, satellite transmitters and other similar facilities used for military tasks);

- the fourth approach identifies information warfare cyber wars (conflict between technical systems).

Aside can not leave the idea of the conflict approach can be considered war analyzed from the perspective of military and political confrontation.

According to this, R. Shafransky study interprets the phenomenon as armed action against any system of knowledge and belief of the enemy, aimed hidden destructive influence on political decisions counterpart, resulting in poor coordination and efficiency of the process. The author emphasizes that the higher technological capabilities and more advanced communication sphere of the state, the more vulnerable it is in the information war $^{18}$.

As to the second of these directions, in the framework esplikuyetsya information war as a political confrontation.

Thus, in the A.V. Manoilo ideas, information warfare - political struggle, expressed in the form of information and psychological operations

${ }^{14}$ Павлютенкова М. Ю. Информационная война: реальная угроза или современный миф? Власть. М. 2001. № 12. С. 23.

${ }^{15}$ Швец Д. А. Информационное управление как технология обеспечения информационной безопасности. Массовая коммуникация и массовое сознание. - М., 2003. 34 с.

16 Манойло А. В. Государственная информационная политика в особых условиях. M. 2013. 290 c.

${ }^{17}$ Шпига П. С. Основні технології та закономірності інформаційної війни. Проблеми міжнародних відносин. 2014. Вип. 8. С. 328.

${ }^{18}$ Szafranski R. Theory of Information Warfare: Preparing For 2020 Official Site of “Airpower Journal”. URL: http://www.airpower.au.af.mil/airchronicles/apj/apj95/spr95_ files/szfran.htm. 
using information weapons and is the essential attribute of political leadership. Implementation of war is the strong influence of the contradictions inherent objective and take place at different levels of social organization. As a result it expected foreign and domestic manifestations of confrontation with a given level of intensity and deliberately organized a specific direction ${ }^{19}$.

The aforementioned position separates Y. Korolev, consider offering information confrontation in relation to regional political process. According to the author, his cause is due to the increase of capital or the powerful protection of their interests. Channel implementation of these strategies are media and political entities are counted as different social groups - the elite of the region and the federal government, audience appropriate media and mass social subject - the region's population as a whole.

State holistic vision of the studied phenomenon can be achieved through systematic approach presented in the works of S.P. Rastorguev, S.N. Bukharin, V.V. Tsyganov.

Basic concepts, used by S.P. Rastorguev - "information system", under which the information war is treated as a public / secret information systems influence one another for the purpose of deformation or destruction of the opposite side. They focus on delivering benefits not only in the material as a political and spiritual spheres, causing public cultural trauma, which leads the dismantling of state.

The systems view of the nature of information warfare expressed as S.N. Bukharin and V. Tsyganov.

They reduce the information war to the dynamic process taking place in a complex self-organizing system with many elements of communication between them are not deterministic and probabilistic nature. This war, according to the authors, resulting from advanced development of any component that requires reallocation of resources in their favor, and increased security. This entails contradictions with other parts of the system and removes it from equilibrium. The result is the transformation of information warfare system or disappearance and formation of a new organization.

In a significant number of scientific papers stated that the concept of "information warfare" mentioned in the directive of the Ministry of Defense of 21 December 1992 in the context of electronic warfare, and since 1996 has been extended term "strategic information warfare (information confrontation)» (Strategic Information Warfare ), because in this way it is presented in the report of the American corporation "Rand" "strategic information warfare. New Face of War »(« Strategic Information Warfare. A new face of War»).

${ }^{19}$ Манойло А. В. Государственная информационная политика в особых условиях. M. 2013. C. 187. 
In 2012, the official definition of "information war" appeared in Ukraine. The Strategic Defense Bulletin of Ukraine (number 771/2012), approved by Decree of the President of Ukraine of 29 December 2012, states: "Information warfare - a form of confrontation between actors (states, blocs, parties, etc.), which provides information on the impact of population the mass media, computer networks, etc. in order to develop appropriate public opinion, undermining the morale of society as a whole and its individual institutions "20.

Since this document is void and the Strategic Defense Bulletin of Ukraine in 2016 (№ 240/2016) ${ }^{21}$ definition of information warfare is no general interpretation of the term again transferred to the rank of contentious issues to vividly discussed in academic and political circles.

What scientists and military disadvantages see the term "information warfare" and why his rather inclined to believe professionalism is situated in a journalistic environment than a real term that can accurately and clearly reflect the properties latest confrontation?

The debate going on over the word "war." Besides him, often using "expansion", "confrontation", "conflict", "operation", "aggression", "impact", "terrorism", "attack", "sabotage", "occupation". Uncertainty timeframe zavualovanist purpose, a new character "weapons" and methods of warfare, the uncertainty relationship with law enforcement activities (information warfare in most cases accompanied by military phase of the conflict or is a prerequisite for it, but not always) leads researchers to abandon the use of the word "war "and resort to substitute.

However, it is now clear that such replacements should not be random: Each of the above terms has its scope of applicability.

Due to the fact that the information war is in an interdisciplinary and complex phenomenon, being in different dimensions, involves the use of techniques conglomerate, the question of overcoming the limited framework of certain theoretical constructs. On this basis, the author of this work finds the need for poliparadyhmalnoho approach to the study of information warfare as one of the aspects of modern social and political reality.

Given the current approach, information warfare should be considered in two main ways: in the broadest sense - as a new form of geopolitical rivalry between the parties (in this case it is advisable used the term "information confrontation") and in a narrower sense - to the sphere of armed struggle (here it is advisable Viko Figure ng term "struggle information").

${ }^{20}$ Стратегічний оборонний бюлетень України. Схвалено Указом Президента України від 29 грудня 2012 року № 771/2012 URL: http://zakon2.rada.gov.ua/laws/show/ 771/2012/paran16\#n16.

${ }^{21}$ Стратегічний оборонний бюлетень України. Введено в дію Указом Президента України від 6 червня 2016 року № 240/2016/ URL: http://www.president.gov.ua/documents/ 2402016-20137. 
Information confrontation aims to achieve public policy in peacetime and wartime. It is logical, objective proc catfish, which has always been and will in the relations between states irrespective of cooperation.

Information wrestling aims to gain and obtain information superiority over the enemy during the preparation and conduct of operations (combat). This involves the provision of a complete, accurate, reliable and timely information about the situation and opportunity management system to realize this advantage in operations (combat) forces (troops) ${ }^{22}$.

Due to its specificity struggle information is either independent view, or an integral part of any other kind of struggle (armed, ideological, economic, etc.). It is time - both civilian and

for war. The scope of information such tremendous struggle, its preparation and organization can not be spontaneous. It must be planned, systematic, based on deep research.

The content of the information fight. Considering the content of information to combat armed conflicts end of the XX century. Note that it is different depending on the stage of conflict.

During peacetime Information must fight secretive nature. Its main content is driving intelligence and political and psychological actions on the enemy, and take measures to ensure their information security. The growing role of play at this stage means of special software and mathematical impact on the resource of technical systems of the enemy. In this period can also be solved by the creation, development, maintaining the desired degree of readiness plans and working effectively combat the use of information resources of its troops (forces) as well as timely and reliable detection and neutralization of information influence opposing side.

IN threatening period added to these tasks and are performed in order to ensure the necessary effectiveness of planned operations (combat). Fully deployed infrastructure management system planned for the fighting groups of troops (forces) with a view to ensuring its maximum potaylyvosti.

To the peculiarities of information struggle in this period include:

- an extreme limitation of use capabilities and methods of information influence on the enemy;

- compliance with existing international law (such as electronic jamming prohibition of certain frequencies and systems Statute of the International Telecommunication Union and the Radio Regulations);

- close interaction between the various law enforcement agencies and government agencies in the event of information struggle.

Since the beginning of hostilities forces and means of combating carry information following tasks:

${ }^{22}$ Опорний конспект лекцій 3 дисципліни «Інформаційні війни» для студентів спеціальності 7.030404 «Міжнародна інформація» / Б.М.Юськів. Рівне: РІС КСУ, 2003. С. 28. 
- a massive influence on resource enemy and prevent a decrease in their combat capabilities of troops (forces) and effective use of their weapons and equipment using an opponent of similar products;

- carrying out measures to reduce the moral and psychological stability enemy and neutralize provide information that affects the moral and psychological state of its personnel;

- conducting information and intelligence and providing potaylyvosti important measures of its troops during the preparation and conduct of operations (combat).

During the combat action information in this period is extremely important to prevent accidental negative impact of its facilities on its information infrastructure facilities ${ }^{23}$.

Main features generalize the notion that the information war - "the highest level of information confrontation aimed at solving social, political, ideological and national, regional and other conflicts between nations, peoples, nations, classes and social groups by transnational corporations large-scale implementation of techniques and methods of violence information (information weapons).

Information warfare pursues global goal: the overthrow of the government changing political and legal regime inspiruvannya civil war as a source of permanent chaos and under controlled entities control this chaos.

Information warfare is not limited in space-time format, because its purpose is to establish a controlled force control algorithm through zastuvannya means of information war "24.

Most papers also noted that the information war - a "set of measures to informational influence on mass consciousness to change behavior and imposing their goals outside the circle of their interests, as well as protection against such influences; a form of informational confrontation between different actors (States, NGOs, economic and other structures), which involves a complex action damaging information area rival parties and protect their own information sphere" 25 .

The flow of information war accompanied by the use of information technologies' impact on information systems, with the aim of misleading mass or individual consciousness, disabling or desynchronization processes of governance and its constituents, notably the military" ${ }^{26}$.

${ }^{23}$ Карпенко В. Інформаційний простір як чинник національної безпеки України. Українознавство: науковий громадсько-політичний культурно-мистецький релігійнофілософський педагогічний журнал. 2005. № 3. С. 182-192.

24 Ліпкан В. А. Сучасний зміст інформаційних операцій проти України. Актуальні проблеми міжнародних відносин. 2011. Випуск 102 (Частина I). С. 34-43.

${ }^{25}$ Малик Я. Інформаційна війна і Україна. Демократичне врядування. 2005. Випуск 15. С. 45-49.

${ }^{26}$ Почепцов Г. Г. Інформаційна політика: навчальний посібник. 2-ге вид., стер. Київ: Знання, 2008. С. 559. 
As you can see, the definition highlights the complex nature activities, availability of a coherent strategy and global objectives impact primarily focus on destruction - in the areas of governance and security orientation to achieve information superiority over the enemy by simultaneous security of their information systems.

\section{Classification of information warfare}

Quite another problem to use the term "information warfare" is a constant variation or replacement of the first word, often within the meaning of "information" refers to the result of "psychological", "communication", "information technology", "unconventional" (not related to the use traditional weapons), "irregular", "virtual". In most cases such nomination only outline the major types and subtypes of the information war.

Typological series of information warfare, which has started a conversation M. Libiki, expanding every year. The division into species occurs mainly on a number of criteria:

- usually considered what to target,

- for what, with which instruments.

Generally distinguish the following types of information warfare:

1) command and management (confrontation or disorder to seize command and control mechanisms in the armed forces of the state);

2) Intelligence (confrontation with the information and intelligence kontrrozvidok);

3) economic and financial (information and economic war for control of trafficking, possession of the information necessary for an advantage over competitors)

4) electronic, hacker, cyberwar (influence of the means of electronic communication - radio, television and computer networks);

5) psychological (carried out by propaganda and manipulation to undermine public spirit, demoralization of the armed forces, to discredit cultural disorientation command of military forces or heads of legislative and executive); psychological war have their subspecies effects used in nature ${ }^{27}$ :

a) information and psychological (promoted certain ideas, attitudes, perceptions, beliefs, creates the foundation for positive or negative mental reaction mass);

b) psychogenic (accompanied by physical factors influences - sound, light, temperature, and the product of shock from some tragic events - death, destruction, etc; consequences - irrational behavior, emotional, emotions, depression, panic);

27 Чистоклетов Л. Г. Інформаційно-психологічні впливи як невід'ємна складова парадигми інформаційної безпеки. Науковий вісник Львівського державного університету внутрішніх справ. 2012. 2(1). С. 183-193. 
c) psychotropic (impact - lateral programming - is performed by transmitting information through unconscious perception; in the case of neurolinguistic programming - with special language programs to change the motivation of people and their behaviors);

6) Networking (complex information actions between social groups in social and professional networks for certain advantages in the economic, military, political, cultural and social confrontations ${ }^{28}$ :

a) high-tech network ( "modern high-tech digital communications that are based on a system of television, radio, the Internet, instant messengers, cellular, satellite and other modern communication and based on gadgets such as fixed computer devices, tablets, smartphones, devices of individual and group communication "29;

b) a network of high-Hume ( "modern high socio - humanitarian technology creation, storage, distribution and retrieval of information; these include SMM, SEO, targeting, contextual advertising, media viruses";

c) let the network sensor ( "Psy high current, making it possible to regulate and manage social communication processes at the level of social groups and individuals, typical in this respect is social psychology, psychoanalysis and applied NLP" ${ }^{30}$.

G. Pocheptsov in the book "Information policy", citing research W. Schwartau, suggests another classification information wars, built "in terms of objects from one person to the whole country." According to this criterion distinguished:

1) personal information war, which include various types of electronic manipulation of personal information;

2) corporate information warfare, which include situations of attack information systems;

3) global information war, where information is regarded as a national achievement by which others can hunt country ${ }^{31}$.

\section{CONCLUSIONS}

From the above analysis implies that the information war in the broadest sense is not allegorical way, it is a socio-political phenomenon and completely fall under the above definition of war. In its fully subject to all the general laws of war. Information warfare is the offensive and defensive components can be carried out in low intensity conflicts and conflicts with the

${ }^{28}$ Курбан О. В. Сучасні інформаційні війни в мережевому он-лайн просторі : навчальний посібник. Київ : ВІКНУ, 2016. С. 48.

${ }^{29}$ The same resourse.

30 Курбан О. В. Сучасні інформаційні війни в мережевому он-лайн просторі : навчальний посібник. Київ : ВІКНУ, 2016. С. 48.

${ }^{31}$ Курбан О. В. Сучасні інформаційні війни в мережевому он-лайн просторі : навчальний посібник. Київ : ВІКНУ, 2016. С. 50. 
use of weapons of mass destruction, at the tactical, operational and strategic levels. Information warfare is characterized by a number of inherent features. Unlike traditional wars, it is much broader in its goals, objectives and spheres of influence. In addition to security forces in this war involved political, financial, industrial and other structures.

Trend scaling information war steadily increases from the interstate character to mizhblokovoho. Nowadays information war is considered as the most efficient and "civilized" and "humane" way kolonializatsiyi one country to another.

\section{SUMMARY}

The article reveals some argued the concept of information warfare, provides a generalized definition of "information warfare."

The focus of the paper, the author focuses on the theoretical and methodological positions of scientists belonging to different academic schools and determine the information war through specific aspects of problems.

The author cites and describes different approaches to the classification of the information war and revealing their content.

\section{REFERENCES}

1. Гриняев С. Концепция ведения информационной войны в некоторых странах мира. URL: http://www.soldiering.ru/psychology/ conception_psywar.php.

2. Живейнов Н. И. Операция «PW»: «психологическая война» американских империалистов. М. 1996. 282 с.

3. Карпенко В. Інформаційний простір як чинник національної безпеки України. Українознавство: науковий громадсько-політичний культурно-мистеиький релігійно-філософський педагогічний журнал. 2005. № 3. С. 182-192.

4. Кіслов Д. Сучасні медіа та інформаційні війни : монографія. Київ. міжнар. ун-т, ін-т журналістики. К. : МП Леся, 2013. 239 с.

5. Костюк I.А. Інформаційні війни в контексті революційних подій в Україні. Актуальні проблеми сочіальних комунікацій: матеріали студентської наукової конферениїі, 22 травня 2014 р. Київ. 2014. С. 57-60.

6. Курбан О. В. Сучасні інформаційні війни в мережевому онлайн просторі : навчальний посібник. Київ : ВІКНУ, 2016. 286 с.

7. Лисичкин В. А., Шелепин Л. А. Третья мировая (информационно-психологическая) война. URL: http://malchish.org/lib/ politics/infwar.htm.

8. Ліпкан В. А. Сучасний зміст інформаційних операцій проти України. Актуальні проблеми міжнародних відносин. - 2011. Випуск 102 (Частина I). С. 34-43. 
9. Малик Я. Інформаційна війна i Україна. Демократичне врядування. 2005. Випуск 15. С. 45-49.

10. Манойло А. В. Государственная информационная политика в особых условиях .М. 2013. 290 с.

11. Михальченко И. А. Информационные войны на рубеже XXI века. Безопасность информационных технологий. 1998. № 3. С. 14-15.

12. Опорний конспект лекцій 3 дисципліни "Інформаційні війни" для студентів спеціальності 7.030404 «Міжнародна інформація». / Б.М.Юськів. Рівне: РІС КСУ, 2003. С. 28.

13. Павлютенкова М. Ю. Информационная война: реальная угроза или современный миф? Власть. М. 2001. № 12. С. 19-23.

14. Панарин И. Н. Информационная война и третий Рим. М. 2001. $244 \mathrm{c}$.

15. Почепцов Г. Г. Інформаційна політика: навчальний посібник. 2-ге вид., стер. Київ: Знання, 2008. 663 с.

16. Проноза I. I. Інформаційна війна: сутність та особливості прояву. Актуальні проблеми політики. Збірник наукових праць. Одеса. 2018.№ 61. С. 121.

17. Саприкін О. Інформаційна експансія, інформаційна війна та інформаційна атака у засобах масової інформації на прикладі Євро-2. Вісник Книжкової палати. 2013. № 1. С. 40-43.

18. Стратегічний оборонний бюлетень України. Введено в дію Указом Президента України від 6 червня 2016 року № 240/2016. URL: http://www.president.gov.ua/documents/2402016-20137.

19. Стратегічний оборонний бюлетень України. Схвалено Указом Президента України від 29 грудня 2012 року № 771/2012. URL: http://zakon2.rada.gov.ua/laws/show/771/2012/paran16\#n16.

20. Чистоклетов Л. Г. Інформаційно-психологічні впливи як невід'ємна складова парадигми інформаційної безпеки. Науковий вісник Львівського державного університету внутрішніх справ. 2012. 2(1). C. $183-193$.

21. Швец Д. А. Информационное управление как технология обеспечения информационной безопасности. Массовая коммуникация и массовое сознание. - М., 2003. 34 с.

22. Шевчук П. Інформаційно-психологічна війна Росії проти України: як їй протидіяти. Демократичне врядування. 2014. Вип. 13. URL: http://lvivacademy.com/visnik13/zmist.html.

23. Шпига П. С. Основні технології та закономірності інформаційної війни. Проблеми міжнародних відносин. 2014. Вип. 8. C. 326-339. 
24. Chris Zambelis Information Wars: Assessing the Social Media Battlefield in Syria. URL: http://www.isn.ethz.ch/Digital-Library/Articles/ Detail/?id=150989.

25. Fukushima K., Miyake S. Pattern Recognition, 1982. V. 15. P. 455-469.

26. Lenat D.B. The Nature of Heuristics. Artificial Intelligence, 1982. Vol. 19. P. 189-249.

27. Szafranski R. Theory of Information Warfare: Preparing For 2020 Official Site of “Airpower Journal”. URL: http://www.airpower.au.af.mil/ airchronicles/apj/apj95/spr95_files/szfran.htm.

\section{Information about the author:}

Pronoza I. I.,

Candidate of Political Sciences,

Senior Lecturer at the Department of Political Sciences and Law, South Ukrainian National Pedagogical University named after K. D. Ushynsky 26, Starofrankivska str., Odessa, 65020, Ukraine 


\section{THE IDEOLOGICAL PARADIGM OF PARLIAMENTARY PARTIES IN MODERN UKRAINE}

\section{Shchedrova H. P.}

\section{INTRODUCTION}

Ideology is an integral part of any socio-political processes. The totality of different values and aspirations may correspond to both the "pure» type of ideologies and the synthesized form that has absorbed guidelines relevant to current historical era. A strong ideological message is able to consolidate society, make it monolithic. On the other hand, with the same level of effectiveness, the ideologically dominant one, as a rule, is not able to influence the political elite, although it is one of the criteria of the typology of the leading political class. Another value of ideology, which the domestic researcher O. Demina points to, is the ability to develop goals and ideals that allow individuals to identify themselves as a community, to establish a connection between people's worldviews and the rules of intersubjective normativity, as well as to determine the relationship between mentality and the behavior standards of society members ${ }^{1}$. Thus, the value of ideology as a system of conceptually formulated presentations, relevant ideas and views on political life is justified and probative, without losing priority in scientific researches.

The ideological component of political parties in political science, as a subject of analysis, has always occupied one of the leading places, in particular, in domestic political science. At the same time, the characteristics of the Ukrainian political parties often emphasized the absence of a stable ideology, since its basic features were often varied, supplemented and replaced by signs of different ideological political trends. However, this did not affect the intensity of the scientific search in Ukraine, which focused on the study of such aspects as the principles of political ideologies (N. Gedikova, F. Kyrylyuk, G. Kuts, M. Yakovlev), the role of ideology in society (V. Gorbatenko, O. Demina, O. Krasnokutsky, O. Makarenko), formation and development of ideological trends in Ukraine (V. Karlova, M. Mykhalchenko, O. Postol, O. Shulga), in particular, in the context of party building (A. Kolodiy, V. Kornienko, O. Matieshyn, M. Prymush, O. Sytnyk, G. Shypunov) and others.

The current stage of state formation in Ukraine was marked by the rich and unprecedented elections of the President of Ukraine and the People's Deputies of Ukraine in 2019. The electoral campaign again actualized such

1 Дьоміна О. Політична ідеологія як духовний регулятив суспільно-політичного розвитку. Грані. 2015. № 12/1 (128). С. 18-24. 
aspects of socio-political life as its ideological dimension and conceptual markers of political choice. Equally important are the commonalities and differences in program statements of parliamentary parties, especially among those with diametrically opposite positions. As a result, scientific research aims to determine the changes and directions of transformation of the ideological paradigm in the political field, on the example of parliamentary parties, which today are the authorized subjects of political and power decision-making. The research objectives are subordinate to these goals, the implementation of which will include the involvement of diverse methodological tools, interdisciplinary approaches and principles of scientific knowledge.

\section{The ideology of modern Ukrainian politics}

In the classical sense, ideology is identified with the core framework of political activity, which encompasses the functioning of all political institutions, institutional relations, personified dimensions of politics and so on and so forth. In the conditions of subordination to the policy of the social sphere of life, it can be argued that the political ideology exerts a permanent pressure on social transformations. The definition of the essence of ideology is formed at the intersection of political science, philosophy, cultural studies, other sciences and even religion. The concept of «ideology» dates back to the 18th century, when in France the attitude towards the idea as an integral part of being began to form. It should be noted that both ideology and its propagandists - ideologists - were in those days perceived in the negative sense as opponents of the current government of Napoleon. A certain categorization of the term was initiated by the French philosopher D. de Tracy. His authorship is the interpretation of ideology as a science of human thinking and social ideas, which must find explanations in the worldview and phenomena of consciousness through the principles of ethics, morality, politics ${ }^{2}$. According to one version, the thinker was looking for a meaningful correspondence to the process of analyzing phenomena and ideas, while rejecting metaphysics and psychology. Instead, he settled on an ideology that, according to D. de Tracy, should have resolved the contradictions in society without interfering with the social structure ${ }^{3}$. One of the modern definitions of ideology was suggested by American professor D. Kettler, who emphasized that it is a set of beliefs and concepts through which occurs the perception and comprehension of the world ${ }^{4}$.

2 Траси А. Д. де. Идеология в собственном смысле слова. М.: Академический Проект. 2013. 332 с.

${ }^{3}$ Лютий Т. Ідеологія: матриця ілюзій, дискурсів і влади. URL: http://ekmair.ukma.edu.ua/bitstream/handle/123456789/12444/3.\%20Liutyi_Ideolohiia_ matrytsia_iliuzii_dyskursiv_i_vlady.pdf?sequence=1\&isAllowed=y. C. 105.

${ }^{4}$ Кеттлер Д. Ідеологія. Енциклопедія політичної думки. К.: Дух і літера. 2000. C. $141-142$. 
However, in the context of the study, we refer to the concept of political ideology, which in the context of Ukrainian realities is appropriate to be perceived through the prism of a functional approach. It is about understanding the ideology as a tool that changes the human mind, changes the world. Its special purpose is to provide a person with the ability to see the past, present and future of the world through a system of interconnected ideas, as well as to bring these principles into human activity, and thus align the world order with these ideas. We can assume that the ideology of domestic politics is more likely not a set of ascertaining values prevailing in society, but a predictive model of order and aspirations that embody the goals of social development.

Drawing on many years of research by the Institute of Sociology of the NAS of Ukraine, A. Shulga analyzes the problem of ideological trends and changes in preferences about them among the population of Ukraine. It is noted that in the early $90 \mathrm{~s}$, almost $60 \%$ of respondents could not say which ideology was closer to them: they had not decided yet, had not understood, or none of the ideological currents had attracted them at all. More than 20 years have passed - and this figure has hardly changed: $55 \%$ of respondents do not choose any of the ideologies as close to themselves ${ }^{5}$. Such trends indicate, in our view, that in the absence of a real ideological choice, society was also unable to formulate a relevant request. As a rule, attention and interest in certain ideas was intensified artificially, using political technologies and manipulations. For example, the state often used the issue of Ukrainian nationalism, the unity of the Slavic nations, the fight against the Soviet past and so on. Some accents have always accompanied the main ideological principle of domestic politics «for all the good, against all the bad», but for «good» and «bad» in each ideology are fixed different values and ideals.

Domestic researcher S. Datsyuk, formulating the vision of Ukrainian ideology, claims that she must choose - whether be weak and marginal or strong and total. The author implies that both a consistent nationalist ideology and a meaningless democratic one eventually turn into total ideologies. At the same time, «Ukrainian politics uses an ideological centaur - a nationaldemocratic ideology with its two conflicting approaches. Two total ideologies cannot be applied in one culture. Only one of them has to survive - either authoritarian nationalism or democratic globalism» ${ }^{6}$. Thus, the thesis is argued that at the present stage of development the new Ukrainian ideology will be

${ }^{5}$ Шульга О. Націоналісти чи ліберали: які політичні течії набирають популярності в Україні. Аналітичний портал «Слово $i$ діло». 22 серпня 2017 p. URL: https://www.slovoidilo.ua/2017/08/22/kolonka/aleksandr-shulha/polityka/naczionalisty-chyliberaly-yaki-politychni-techiyi-nabyrayut-populyarnosti-ukrayini.

${ }_{6}^{6}$ Дацюк С. Погляд на можливість нової ідеології Часопис «Ï». 2012. URL: http://www.ji-magazine.lviv.ua/dyskusija/2012/Dacyuk_Pohlyad_na_mozhlyvist_nov_ ideolog.htm. 
extremely fragmentary, having absorbed the features of the national and democratic, but getting rid of traits of the total.

Emphasizing that ideology in Ukraine should serve the purpose of setting, it turns out that political ideology, or ideology of politics, should develop and establish a set of goals to which would be subject to the political institutions. The events in Ukraine over the past six years that twice led to a change in the political elite showed a common desire of citizens to uphold democratic values protection of individual rights and freedoms, support of private property, fair competition and market relations, fight against corruption, increased transparency of public policy, guarantees of freedom of foreign policy choice and so on and so forth. A kind of wrapper for such a set of goals could be the ideology of liberalism, the essence of which is the protection and support of the common good through the protection of the individual.

The liberal mechanism, described in due time by the English thinker J. Locke, provides for the conclusion of a social contract between the population and the authorities. It looks as if the new Liberal government is taking responsibility for the realization of socially important aspirations. In case of of non-fulfillment of its obligations, the government may be changed peacefully or removed by revolutionary means. At first glance, a simple mechanism in Ukraine has a number of nuances in practice. Firstly, in the conditions of the formation of a liberal ideology, governments may not be liberal, provoking a dissonance between existing corruption and the values of liberalism. Secondly, the postulates of liberalism completely legalize the events of the Revolution of Dignity 2013-2014, when the people exercised their right to remove power that did not fulfill the terms of the social contract.

It is appropriate to draw a parallel with the eastern neighbor, the Russian Federation, where the values of liberalism in the current conditions are perceived as a hostile ideology of the current authorities. That is why the format of the Russian opposition is characterized as «liberal», and its actions are gradually taken outside the conventional legal field. This is a sort of a manifestation of half-liberalism when the people were only entitled to elect a ruler, but did not have the authority to control, criticize and change him. Concerning the functional dimension of ideology, we note that there is a distortion of the content of ideology, which essentially subordinates socially important ideas to the actual state order. In Ukraine, however, the liberal mechanism does not work, say, in the part of the civic political consciousness due to low levels of participation in elections, interest in studying political programs, personified assessment of political forces, etc.

Returning to the statement about the fragmentation of the ideology of Ukrainian politics, let us dwell on manifestations of conservatism. It was reflected mainly in the functioning of the political elite and the ideology of its self-perception, which, despite the change of personalities, still prefers 
established methods and principles of activity. Conservative, or rather stably closed, remain internal institutional and institutional relationships, also associated with an unsettled system of checks and balances. Reforming the system of public administration in the conditions of preservation the previous powers, preferences and in the absence of modernization of institutional competencies is a national feature of domestic conservatism. This is one of the reasons why the process of circulation of political elites in our country is not full and complete. At the same time, politicians in Ukraine cannot acquire classical features of conservative ideology due to a number of objective reasons: firstly, there are practically no carriers of this doctrine in the state, and secondly, within the framework of independent state, Ukraine has no acquired values or principles that can be «conserve».

According to the liberal component of the ideology of politics in Ukraine, it is worth adding about those features that give the right to call our liberalism formal. These include the existence of a number of political parties which, in their own name, have laid membership in the values of liberalism (the Liberal Party of Ukraine, the Liberal Democratic Party of Ukraine, the Christian Liberal Party of Ukraine, the Political Party «Liberal Ukraine», etc.), and the constitutional consolidation of major liberal values (protection of human rights and freedoms and decent living conditions, guaranteeing freedom of thought and speech, inviolability of private property, protection of competition in business activities, etc.). These features are mainly declarative and do not affect the implementation of public policy. Yes, none of the listed parties get to the parliament on their own.

Another criterion for measuring liberality is the maturity level of civil society. The German Liberal Policy Fund, «the Friedrich Naumann Foundation for Freedom», proposes this definition: «a liberal state is a civil society in which the state does not oppose the citizen as a powerful government but in which the citizen is a state» ${ }^{7}$. From this point of view, it is important to recall the expert study of the Civil Society Stability Index in Ukraine, which in 2018 has fallen by 0.1 points compared to 2017. Experts point out that the decline was due to a significant deterioration in two blocks: the legal environment and advocacy ${ }^{8}$. Specifying the causes of this situation, were mentioned the attacks on activists and campaigns to discredit their activities, efforts to introduce additional reporting for all public organizations with burdensome procedures, etc. The NGO advocacy index, that is, the ability to influence processes, has fallen by 0.1 points, as a number of reforms initiated by the non-governmental sector have not been implemented. There is

${ }^{7}$ Фонд Фрідріха Науманна за Свободу. URL: https://ukrajina.fnst.org.

${ }^{8}$ Індекс стабільності громадянського суспільства в Україні у 2018 році погіршився на 0,1 пункта - звіт. Украӥнський кризовий медіа-центр. 2019. URL: http://uacrisis.org/ua/ 73649-civil-society-index-2018. 
also still a significant difference between the achievements of public organizations in big cities and at the local level.

Improvements include the simplification of the procedure for state financing of public organizations.

At the same time, there is a public perception of civil society, whose measurements in 2019 showed that involvement in civic activities in Ukraine remains low, but awareness of activism and interest in it has a positive dynamic. $40.5 \%$ of respondents assess the level of civil society development as average, while $34 \%$ of respondents give a negative assessment and $12 \%$ give a high rating. The level of non-involvement of citizens in public organizations is noticeable - the indicator of $7-8 \%$ has not changed in the last six years, but answers about the reasons have been changed - from the lack of time in 2013 to the lack of interest in $2019^{9}$. Therefore, the state of development of civil society remains diverse and unstable, it still depends on state intervention, which can be considered systematic adoption of normative documents that are intended to influence the process of institutionalization of civil society (for example, National Strategy for Promoting Civil Society Development).

According to non-classical political ideologies, in Ukraine one can watch only situational and rather controlled manifestations of nationalism that does not find mass support among the population. In the context of adaptation to the Ukrainian realities of postmodern ideologies, in particular environmentalism and feminism, relevant non-governmental organizations play their active role, which directly or indirectly interacting with political institutions, but do not play a significant role in the functioning of the political system. However, we add that, for example, the principle of equal opportunities for men and women is enshrined in the Statute and in the program of the "European Solidarity» political party, which is a kind of precedent for Ukraine.

The aim of consolidating Ukrainian society is also linked to a certain unifying ideology, defining it as nationwide and not identifying it with a particular political institute. Social democracy, social liberalism, liberal nationalism, pan-Europeanism, center-right politics, Christian democracy - the spectrum of value orientations in domestic politics has no common vector. On the one hand, such a vector may contradict the established principle of political and ideological pluralism, on the other - it is entirely consistent with the interests of building a viable nation state. According to the Ukrainian researcher V. Karlova, the widely publicized and actively implemented idea of «deideologization» and «depoliticization» after the collapse of the USSR led to negative consequences - «ideological vacuum» and destabilization of social development, a significant weakening of the foundations of the new

${ }^{9}$ Громадянське суспільство в Україні: погляд громадян. Фонд «Демократичні ініціативи імені I. Кучеріва». URL : https://dif.org.ua/article/gromadyanske-suspilstvo-vukraini-poglyad-gromadyan. 
statehood $^{10}$. In this regard, well-known researcher M. Golovatyi rightly noted that unprincipled, non-ideological societies do not exist in nature now, because any activity of people and nations is driven precisely by ideas, the system of values in which society grows and on which it is based ${ }^{11}$.

Although the Constitution of Ukraine enshrined the principle of political, economic and ideological pluralism, this document can also be considered as a certain list of rules and values of a particular nationwide ideology. The reasons that it has not yet been able to fully realize its function of consolidation of society are due to the lack of proper political and legal culture and respect for the Basic Law, problems of balance of power, the elite's rejection of the rule of law principle - first of all, the need for the application and interpretation the norms of the right to be guided by the interests of the individual and society, not by an official, party or state. Based on the principle of universal subordination of the Constitution to all political decisions and political and social norms, this document, which has been praised in the countries of developed democracy, could become a kind of ideological manifesto of Ukrainian national ideology.

The main carriers of ideologies in Ukraine, as in other states, are whether there should be political parties, which by definition form the ideological spectrum of the political sphere in the country. A number of studies in their conclusions substantiate the thesis that there are no ideological parties in Ukraine.

\section{Program goals of domestic parliamentary parties: a comparative analysis}

The study of the ideological foundations of party programs is updated in Ukraine during each electoral campaign. The use of different approaches and techniques every time finds new arguments in favor of the absence of parties with certain ideological orientation in the state. Moreover, ideology that is often declared by party leaders does not correspond to the party's program goals or contradict the name of the party and so on. Elections to the Verkhovna Rada of Ukraine in the summer of 2019 caused a new stage in increasing attention to the ideological analysis of the programs of political parties. According to the result of the will of the citizens, having overcome the five percent barrier, five political forces entered the parliament - a political party «Servant of the People» (43.16\%), a political party «Opposition Platform - For Life» (13.05\%), a political party All-Ukrainian Union «Batkivshchyna»

10 Карлова В. Проблеми формування загальнонаціональної ідеології в Україні. Вісник Національної академії державного управління. 2013. № 11. URL: http://visnyk.academy.gov.ua/wp-content/uploads/2013/11/2010-4-4.pdf.

${ }^{11}$ Головатий М. Ідейні засади розбудови Української України: стан та проблеми. Персонал. 2007. № 1. С. 14. 
(Fatherland) (8.18\%), a political party «European Solidarity» (8.1\%), a political party «Voice» $(5.82 \%)^{12}$. Among the current parliamentary parties, two are new political forces («Servant of the People», «Voice»), two continued their activities by changing their names («Opposition Platform - For Life», «European Solidarity»), one already breaking the electoral barrier to the Rada (All-Ukrainian Union «Batkivshchyna»). We emphasize the aspects embedded in the programs of these parties, finding out the common and distinct features in the ideologies of political opponents.

The analysis of the relevant documents submitted by the party organizations to the Central Election Commission during the election campaign showed the prevalence of common ideas and aspirations of the current parliamentary parties. We emphasize that these common features mainly reflect the values of liberal ideology, namely, various freedoms, respect and protection of human rights, support for the development of civil society and youth, development and implementation of innovations, reduction and optimization of taxes, protection of private property and entrepreneurship, development of markets through politics demonopolization, encouraging community initiative in the context of continuing the decentralization reform. The principle of protection freedom of speech, which recently has become especially relevant, has even been brought to some points in party programs: the impossibility of controlling the media («Voice»), to deprive media owners of the opportunity to influence the journalists’ activities («Servant of the People»).

Each party formulated its dominant markers: the defense sector and Euro-Atlantic integration in «European Solidarity», peace and personnel reloading of power in "Servant of the People», consolidation of the population, the return of neutrality and multi-vector policies in «Opposition Platform - For Life», a new economic course of a country in All-Ukrainian Union «Batkivshchyna» (Fatherland) and justice through overcoming corruption and monopolies in «Voice» ${ }^{1314151617}$. Issues of war and peace and the vector of foreign policy became the fundamental aspects that touched upon all program documents. Thus, the formula of peace through victory is supported by the parties «European Solidarity» and «Voice», peace through

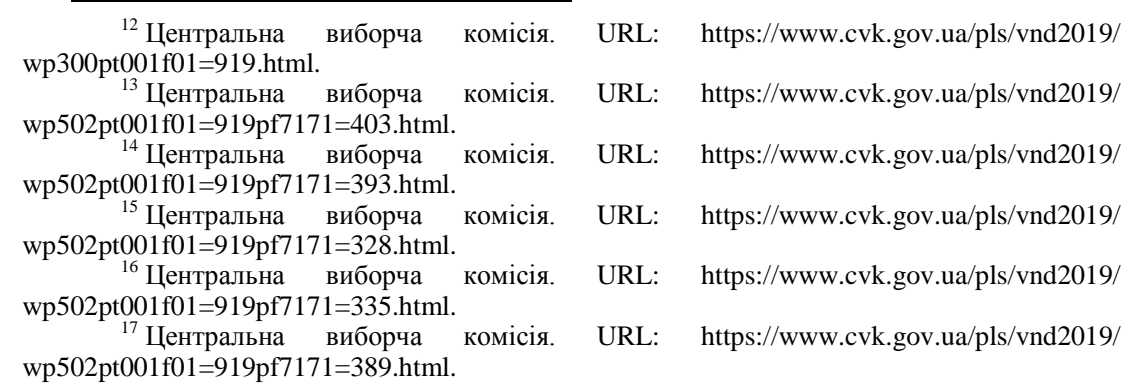


involvement and expansion of international institutions appears in «Batkivshchyna» (Fatherland) program, peace through dialogue and compromises in «Opposition Platform - For Life». «Servant of the People» party relied on President V. Zelensky in this, promising in the program «to provide legislative support to Presidential initiatives aimed at restoring the territorial integrity and state sovereignty of Ukraine» ${ }^{18}$.

Certainly, foreign policy was determined through the prism of choice between West and East. Support for Ukraine's accession to the European Union and NATO is enshrined in the programs of three political forces «European Solidarity», «Batkivshchyna» (Fatherland) and «Voice». «Servant of the People» assumes the responsibility to fulfill the Association Agreement with the European Union, as well as to expand cooperation with the EU and NATO, but does not fix the purpose of joining these organizations. «Opposition Platform - For Life» supports the opposite opinion, which supports political multi-vectorism, active neutrality, revision of conditions for Ukraine's participation in the World Trade Organization and the Free Trade Area with the EU, and the restoration of trade and economic ties with the Russian Federation and CIS countries ${ }^{19}$.

In our opinion, the program of the political party «Opposition Platform - For Life» is the most controversial in terms of the promoted principles. On the one hand, the party is in favor of a comprehensive policy of reconciliation and consent in order to consolidate the population, insisting on the introduction of a "moratorium on topics that split the country». On the other hand, the document contains theses on the autonomy of the Donbas, amnesty for the participants in the war in the east of the country, restoration of ties with Russia, providing training in Russian and languages of national minorities, etc. These items do not quite fit the criterion of consolidation and are quite ambiguously perceived by different parts of the Ukrainian population. At the same time, the party identified its program as a «fair social contract between the party and the Ukrainian people», which is the classic tenet of liberalism. The mechanism of liability for non-compliance with the contingent clauses of such an agreement has not yet been regulated by domestic legislation.

The issue of land sale, which is on the agenda in the state, was reflected only in the programs of two parties: All-Ukrainian Union «Batkivshchyna» (Fatherland) strongly opposed the sale of agricultural land, and «Opposition Platform - For Life» left the right to make a final decision through an allUkrainian referendum. By the way, «Servant of the People» also suggested

${ }^{18}$ Центральна виборча комісія. URL: https://www.cvk.gov.ua/pls/vnd2019/ wp502pt001f01=919pf7171=403.html.

${ }^{19}$ Центральна виборча комісія. URL: https://www.cvk.gov.ua/pls/vnd2019/ wp502pt001 f01=919pf7171=393.html. 
the initiative of actively introducing such form of communication with the population as referendums.

By visualizing the texts of party programs using the Tag Cloud service, you can capture also word markers that characterize certain party priorities in one way or another. For "Servant of the People», it is mainly the verb «we will introduce», "we will create», "we will carry out», "we will deprive», "we will transfer»; for «Opposition Platform - For Life» - «policy», «Donbass», «security», «priority steps», for «Batkivshchyna» (Fatherland) - «we», «new», «insurance», «account» and a number of other economic terms, for «European Solidarity» - «citizens», «EU», «promote», «development», «life», and for «Voice» - «we», «people», «state», «victory» (Fig. 1). In the context of usage of this service, the word «Ukraine» was found common in four political forces (except All-Ukrainian Union «Batkivshchyna» (Fatherland)). Of course, this approach cannot be considered scientifically valid, so we do not analyze the visual part, but only state it as a fact.

One of the reasons that each program can be called declarative is the principles of further parliamentary activity. There were almost no points of contact in the inter-factional interaction of the victorious political parties in the Verkhovna Rada of Ukraine of the IXth convocation, despite calls for unity and consolidation, the common vision of the fundamental principles of state formation in the context of protecting the rights and freedoms of citizens, minimizing bureaucratic pressure, building a healthy society. The situation is balanced by the unprecedented formation of a mono-majority of deputies of the political party «Servant of the People» (252 deputies) (Fig. 1).

The statutes of political parties also formulate certain ideological principles, but rarely specify them. In particular, a clearly defined ideological affiliation is not enshrined in the Statute of «European Solidarity», which is still on the official site of the Petro Poroshenko Block «Solidarity». The document states that party secretariats provide the ideology of the party, but but there is no fixed ideological dominance, only the protection of «universal human values» and participation in the development of a «sovereign, legal, democratic, socially oriented and economically developed state» are mentioned ${ }^{20}$.

The Statute of the All-Ukrainian Union «Batkivshchyna» (Fatherland) has been formulated in the same way. However, the charter document states that «being an associate member of the European People's Party as an alliance of centrist and Christian-democratic parties on the continent, it fully and completely shares the worldviews stated in the main EPP program documents» ${ }^{21}$. Theses on protection of «universal human values» and «achievement and

${ }^{20}$ Статут політичної партії «Блок Петра Порошенка «Солідарність». URL: https://solydarnist.org/wp-content/uploads/2016/12/statut_solidarnist.pdf.

${ }^{21}$ Статут Всеукраїнське об'єднання «Батьківщина». URL: https://ba.org.ua/ wp-content/uploads/2017/12/statut14-6.pdf. 
constant improvement of social justice and high standard of living, full membership of Ukraine in the European Union, alignment with European standards of social sphere, economy and political system» are also present.

The values professed by the «Opposition Platform - For Life» are enshrined in the section of the Statute of the Party Task, in particular, are about «ensuring the perception of a person as the highest social value», "promoting the formation of a civil consciousness among the population of Ukraine, based on the national interests of the state and universal human values», etc ${ }^{22}$. Characterizing the ideology of the party from the outside, experts point to its tendencyto socialism, social democracy and social liberalism, and more critical towards Russophile social liberalism.

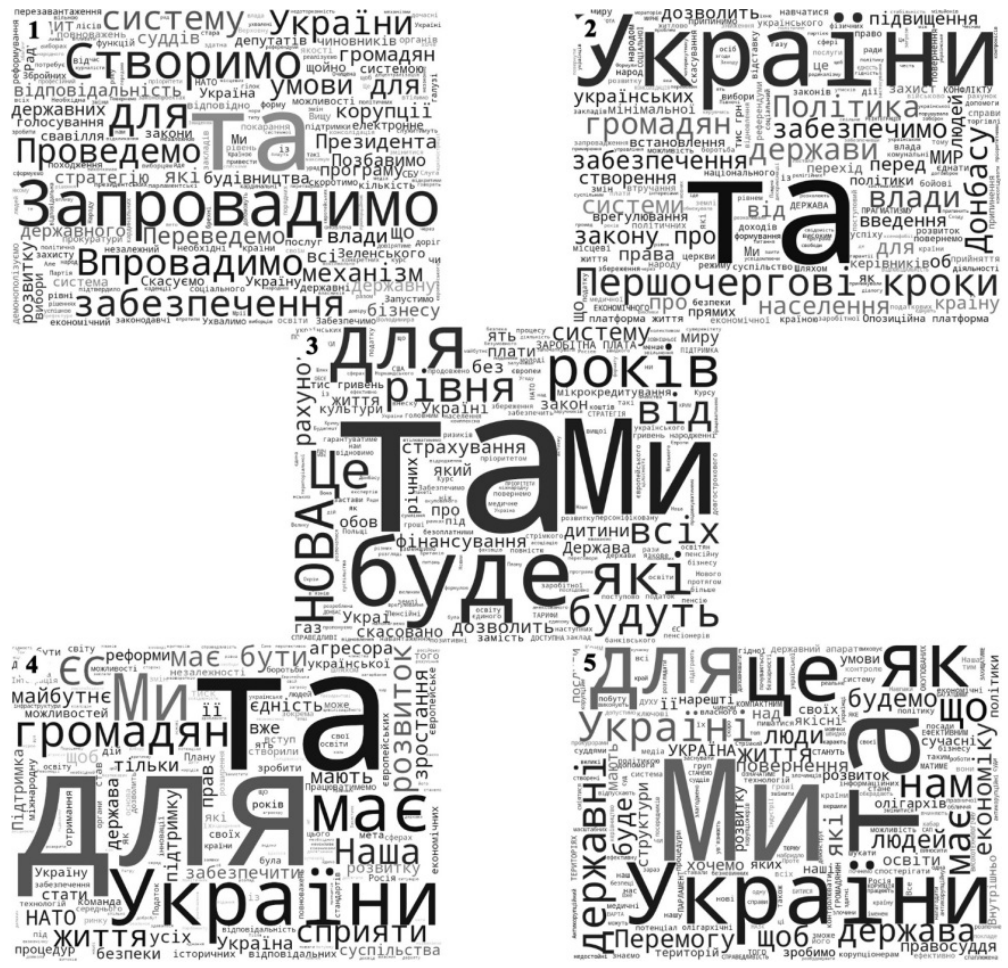

Fig. 1. Political party programs in tag cloud format (1 - Servant of the People, 2. - Opposition Platform - For Life, 3 - Batkivshchyna (Fatherland), European Solidarity, 5 - Voice)

${ }^{22}$ Статут політичної партії «Опозиційна Платформа - За Життя». URL: http://zagittya.com.ua/ua/page/ustav.html. 
The newly created political parties «Servant of the People» and «Voice» did not make their charters public.

In the absence of stable ideological norms, Ukrainian political parties are still often characterized as «interest clubs» or «political projects», emphasizing certain manifestations of leadership. In our view, the last statement is based on the predominance of the party's personalized perception over its ideological superstructure. In general, this is still one of the leading features of domestic politics. According to researcher S. Grabovsky, this situation is caused by the fact that Ukraine is late with the establishment of political parties on the European model. In the late 1980s in Ukraine, as well as in its western neighbors, a number of political parties emerged with a clear ideology and program of action. But unlike the countries of Central and Eastern Europe and the Baltic States, where parliamentary elections were held immediately after the fall of communism on party lists, there were no such elections in Ukraine until 1998. By that time, merging of parties and business had already occurred, which did not contribute to the continued existence of ideological parties ${ }^{23}$.

Another reason for the de-ideologization of political parties in Ukraine is the response to society's request. We mean that citizens are waiting for a leader, not an ideology. This is evidenced by data from sociological surveys over the last three years. Thus, in 2017, almost half of the respondents said that there are no political leaders in Ukraine who could effectively run the country $^{24}$. In 2018, 62\% of citizens believed that Ukraine needed new political leaders (in 2013, 49\% of respondents said this). It was emphasized that such leaders should emerge from new political forces (33.5\%), existing nonprimary political parties (30\%), civil society organizations (28\%) and humanitarian or technical intellectuals $(26 \%)^{25}$. In 2019, $67 \%$ of the respondents said that Ukraine needs a leader who is able to unite, reconcile and calm society; $24 \%$ - for a leader inclined to dictatorship and rigid ordering $^{26}$. It is significant that according to the analytical platform VoxUkraine, in the summer of 2019 most Ukrainians were inclined to believe that the state should have a strong influence on both the economy and personal

${ }^{23}$ Грабовський С. Ідеологічні партії в Україні зникли, бо ж на партійну діяльність завжди потрібні гроші. Радіо Свобода. 22 червня 2017 p. URL: https://www.radiosvoboda.org/ a/28572938.html.

${ }^{24} 45,5 \%$ українців не бачать гідного політичного лідера - опитування. Украӥнська правда. 14 грудня 2017 p. URL: https://www.pravda.com.ua/news/2017/12/14/7165529.

${ }^{25}$ Дві третини українців хочуть бачити нових політичних лідерів. Дзеркало тижня. Дві третини українців хочуть бачити нових політичних лідерів. 1 серпня 2018 р. URL: https://dt.ua/UKRAINE/dvi-tretini-ukrayinciv-hochut-bachiti-novih-politichnih-lideriv284545_html.

${ }^{26}$ Моніторинг електоральних настроїв українців: січень 2019. Сочіологічна група «Рейтинг». URL: http://ratinggroup.ua/research/ukraine/monitoring_elektoralnyh_nastroeniy_ ukraincev_yanvar_2019.html. 
freedoms. Previous studies have shown that most members of influential political forces were also inclined to believe $\mathrm{so}^{27}$. This is a significant coincidence of the positions of Ukrainian citizens and party leaders on the political compass, where liberal values lose their positions.

In general, Ukraine systematically demonstrates a tendency towards left-wing or left-centrist ideologies in times of economic decline and political crises. As a consequence of the Soviet past, these trends are subconsciously associated with citizens with state guarantees of well-being, even if their level is minimal and such that it does not correspond to a sufficient level of needs.

Along with the classical types of ideology, domestic practice forms its own ideological spectrum - the ideology of peace associated with military operations in the Donbass, the European ideology based on European values and formed under the influence of the process of European integration, and the ideology of populism, which is determined by the opposition of political slogans and the activation of party activity during of the electoral process.populism and political ideology. All these facts indicate that the ideologization of political space in Ukraine is transforming in the direction of acquiring responses to the challenges and needs of a particular historical period, borrowing values from outside by engaging in global politics and gravitating towards a certain international community.

\section{CONCLUSIONS}

The concept of «political ideology» has come a long way in evolution, and in the modern dimension is interpreted as a steady set of values, guidelines and aspirations that correspond to the current state of political life. Political ideology in Ukraine is rather a prognostic model of the order that society expects.

The ideological superstructure of national state formation is characterized by a combination of national (due to the political past) and democratic (corresponding to modern challenges and trends) aspects. On the way to the perception of liberal values, Ukraine faces difficulties in implementing the mechanism of concluding the so-called «social agreement». The unstable system of checks and balances, the lack of effective channels of communication between citizens and the political elite, the high level of distrust in government bodies and the disappointment in the activities of political institutions have led to several large-scale crises of confidence in the authorities. Correct the situation should the systematic formation of a national idea and a consolidating state ideology, the conductors of which would be political parties.

${ }^{27}$ Що думають українці про державний контроль економіки та особистих свобод? VoxUkraine. 5 червня 2019 p. URL: https://voxukraine.org/uk/sprava-nalivo-shho-dumayutbilshist-ukrayintsiv-pro-derzhavnij-kontrol-ekonomiki-ta-osobistih-svobod. 
Political parties of Ukraine mention the ideology and values quite often, but they almost never specify these concepts, using, for example, categories such as «universal human values», «European values» or «principles of democracy». These terms are rather vague and always have their own specifics due to the peculiarities of the political regime, the level of institutionalization of the state-making apparatus, the state of political culture and the political elite. Liberal values, which are universal in accordance with the requirements and needs of the time, have become the most popular in the declarative part of the activities of parties. They are reflected in both party programs and statutes, but in the real work of parliamentary parties they are often combined with the values of socialism and conservatism. Ideological principles are often replaced by political technologies, such as the manipulation of slogans that are often changed.

The characterization of party ideologies as declarative or decorative is not a negative feature of parties as such, but rather indicates a certain deideologization of political parties in Ukraine, the level of their maturity as a political institute. Among the factors and features of party functioning in domestic partogenesis, we note the establishment of stable party structures and their territorial organizations, with respect to transparent financial reporting. Aspects of ideological design and, in particular, ideologies of internal party relations remain fragmentary and deformed. We assume that this is a consequence of both the lack of personal experience in building political parties and the destructive consequences of mono-party system and monoideology in the last few decades before Ukraine gained independence.

\section{SUMMARY}

The question of ideology has always been an important topic of public debate, but the ideological component of socio-political life is on the state's default agenda - without the development and progress of holistic paradigm. The vision of ideology, both at the level of the state and its individual institutions, as well as at the civic level, are rather blurred and fragmented liberal ideas with an admixture of center-right elements and left-wing values. On the one hand, this is a sign of the embodied pluralism of thoughts, on the other - the result of a scattering needs, aspirations and guidelines in the conditions of the state's inability to produce a constant set of consolidating ideas.

Political parties as leaders of ideological trends in Ukraine are characterized as deideologized, but not devoid of the markers of certain ideologies - social democracy, social liberalism, pan-Europeanism, rightcentrism, etc. In the conditions of the declarations of political slogans, we note the rise of populist ideology, which intensifies its manifestations in the electoral period. The reasons for such tendencies can be considered the lack of historical experience of building ideological parties, the rate on personification 
of the party, not the formation of its ideological superstructure, the lack of demand for ideology from a society, which, first of all, requires a political leader with a certain set of managerial and individual qualities.

The level of maturity of ideology in society, the state, and political parties is a measure of the level of maturity of socio-political relations. Awareness of common goals and priorities will be the key to further developing a nationwide system of political values.

\section{REFERENCES}

1. 45,5\% українців не бачать гідного політичного лідера - опитування. Українська правда. 14 грудня 2017 p. URL: https://www.pravda. com.ua/news/2017/12/14/7165529.

2. Головатий М. Ідейні засади розбудови Української України: стан та проблеми. Персонал. 2007. № 1. С. 12-18.

3. Грабовський С. Ідеологічні партії в Україні зникли, бо ж на партійну діяльність завжди потрібні гроші. Paдіо Свобода. 22 червня 2017 p. URL: https://www.radiosvoboda.org/a/28572938.html.

4. Громадянське суспільство в Україні: погляд громадян. Фонд «Демократичні ініціативи імені I. Кучеріва». URL : https://dif.org.ua/article/ gromadyanske-suspilstvo-v-ukraini-poglyad-gromadyan.

5. Дацюк С. Погляд на можливість нової ідеології. Часопис «ї». 2012. URL: http://www.ji-magazine.lviv.ua/dyskusija/2012/Dacyuk_ Pohlyad_na_mozhlyvist_nov_ideolog.htm.

6. Дві третини українців хочуть бачити нових політичних лідерів. Дзеркало тижня. 1 серпня 2018 p. URL: https://dt.ua/UKRAINE/dvi-tretiniukrayinciv-hochut-bachiti-novih-politichnih-lideriv-284545_html.

7. Дьоміна О. Політична ідеологія як духовний регулятив суспільно-політичного розвитку. Грані. 2015. № 12/1 (128). С. 18-24.

8. Індекс стабільності громадянського суспільства в Україні у 2018 році погіршився на 0,1 пункта - звіт. Украӥнський кризовий медіацентр. 2019. URL: http://uacrisis.org/ua/73649-civil-society-index-2018.

9. Карлова В. Проблеми формування загальнонаціональної ідеології в Україні. Вісник Наиіональної академії державного управління. 2013. № 11. URL: http://visnyk.academy.gov.ua/wp-content/uploads/2013/ 11/2010-4-4.pdf.

10. Кеттлер Д. Ідеологія. Енциклопедія політичної думки. К.: Дух і літера. 2000. $472 \mathrm{c.}$

11. Лютий T. Ідеологія: матриця ілюзій, дискурсів і влади. URL: http://ekmair.ukma.edu.ua/bitstream/handle/123456789/12444/3.\%20Liutyi_Ide olohiia_matrytsia_iliuzii_dyskursiv_i_vlady.pdf?sequence=1\&isAllowed=y. 
12. Моніторинг електоральних настроїв українців: січень 2019. Соиіологічна група «Рейтинг». URL: http://ratinggroup.ua/research/ukraine/ monitoring_elektoralnyh_nastroeniy_ukraincev_yanvar_2019.html.

13. Статут Всеукраїнське об’єднання «Батьківщина». URL: https://ba.org.ua/wp-content/uploads/2017/12/statut14-6.pdf.

14. Статут політичної партії «Блок Петра Порошенка «Солідарність». URL: https://solydarnist.org/wp-content/uploads/2016/12/statut_ solidarnist.pdf.

15. Статут політичної партії «Опозиційна Платформа - За Життя». URL: http://zagittya.com.ua/ua/page/ustav.html.

16. Траси А. Д. де. Идеология в собственном смысле слова. М.: Академический Проект. 2013. 332 с.

17. Фонд Фрідріха Науманна за Свободу. URL: https://ukrajina.fnst.org.

18. Центральна виборча комісія. URL: https://www.cvk.gov.ua.

19. Шульга О. Націоналісти чи ліберали: які політичні течії набирають популярності в Україні. Аналітичний портал «Слово $i$ діло». 22 серпня 2017 p. URL: https://www.slovoidilo.ua/2017/08/22/kolonka/ aleksandr-shulha/polityka/naczionalisty-chy-liberaly-yaki-politychni-techiyinabyrayut-populyarnosti-ukrayini.

20. Що думають українці про державний контроль економіки та особистих свобод? VoxUkraine. 5 червня 2019 p. URL: https://voxukraine.org/ uk/sprava-nalivo-shho-dumayut-bilshist-ukrayintsiv-pro-derzhavnij-kontrolekonomiki-ta-osobistih-svobod.

Information about the author: Shchedrova H. P., Doctor of Political Sciences, Professor, Head of the Department of Political Science and International Relations, Higher educational institution "Alfred Nobel University» 18, Sicheslavska Naberezhna str, Dnipro, 49000, Ukraine 


\title{
DIGITALIZATION IN THE FIGHT AGAINST CORRUPTION IN UKRAINE
}

\author{
Silenko A. A.
}

\section{INTRODUCTION}

The relevance of the article is due to the fact that in 2019. in the ranking of Corruption Perception Index, Ukraine took 127th place among 180 countries. Among neighbors, the worst performance is only in Russia ${ }^{1}$.

According to the results of a sociological survey conducted in 2018. Ilk Kucheriv Foundation for Democratic Initiatives, together with the sociological service of the Razumkov Center on August 16-22 in all regions of Ukraine, except Crimea and the occupied territories of Donetsk and Lugansk regions, $26.1 \%$ of Ukrainians are ready to rally against corruption ${ }^{2}$.

This is three times IU nshe than 2012- 2013 g., While according to the study's Global Corruption Barometer (of Global Corruption Barometer) from by Transparency International, and Gallup International, Association viyasnilos that protest against corruption are ready $68 \%$ of Ukrainians ${ }^{3}$.

Do these research findings suggest that corruption has decreased? Unfortunately not. By orruptsiya Prodo lzhaet to be one of the most dangerous problems that hinder the development of Ukraine. Corruption discourages investors, hinders the full filling of the budget, destroys state institutions, the political system, and threatens national security.

According to Article 20 of the UN Convention against Corruption, the concept of non- legal enrichment "is understood as" a significant increase in the assets of a public official in excess of his legal income, which he can not reasonably substantiate. The world community recognizes the usefulness of recognizing illegal enrichment "as a criminal offense when it is committed intentionally", because the discrepancy between the declared income and the real costs of corrupt officials is much easier to justify than their specific corruption actions ${ }^{4}$.

${ }^{1}$ Рейтинг восприятия коррупции: Украина поднялась выше, но до сих пор отстает от соседей. Available from https://www.bbc.com/ukrainian/news-russian-47041703

${ }^{2}$ Если власть не прибегнет к насилию: эксперты рассказали, готовы ли украинцы выходить на акции протеста. Available from: https://styler.rbc.ua/rus/zhizn/esli-vlast-pribegnetnasiliyu-eksperty-rasskazali-1536955375.html.

${ }^{3}$ Каждый третий в Украине готов выйти на улицу из-за коррупции. Available from: http://www.pravda.com.ua/rus/news/2013/07/9/6993866/.

${ }^{4}$ Борьба с коррупцией - зарубежный опыт: от Швеции до Сингапура. Available from: http://argumentua.com/stati/borba-s-korruptsiei-zarubezhnyi-opyt-ot-shvetsii-do-singapura. 
In fairness, it should be noted that corruption is a problem not only in Ukraine. It is in almost all countries to one degree or another. And the fight against corruption is not always successful. So, despite the fact that such authoritative international organizations as the World Bank, the European Commission, Transparency International take an active part in anti-corruption reforms in the countries of Central and Eastern Europe, corruption has not been overcome. Rasmo Karklinks writes about this in his work "The system forces me to do this", that despite the increase in anti-corruption measures in post-communist countries, their implementation did not lead to a real increase in accountability, due to a lack of political will, as a result of which the trend towards the formation of informal networks intensified, the development of patrimonialism, clientism, nepotism and the like practices" ${ }^{5}$.

And it appeared not today, but from the moment the state appeared as a socio-political institution. The problem of corruption was very worrying for Napolen, who considered it extremely dangerous for the army and the state. In order to combat the embezzlement and theft of army resources, a special system was developed that regulates public procurement ${ }^{6}$.

Corruption has become the subject of scientific writings of the famous philosophers Platon, Aristotle, T. Hobbes, N. Machiavelli, S. Montesquieu and others. The great sociologists E. Durkheim, G. Simmel, M. Weber, T. Parsons presented their views on this problem. R. Merton, P. Berger and others. The problems of electronic government were dealt with by Ukrainian researchers E. Emelianenko, I. Kusplyak, N. Kruk and others.

Note that the purpose of this article is to prove that digitalization can influence corruption and reduce its level. However, we do not claim that digitalization is the main way to fight corruption. Although such stereotypes exist today in domestic and foreign literature. Of course, other factors, for example, socio-cultural and psychological, play an important role in creating an anti-corruption environment.

You can share a few basic factors that influence the effectiveness of launching e electrons government in Ukraine.

\section{The willingness of the population to the EC to use the e-government}

One of the most important indicators of lifestyle changes in the second half of our century is the development and use of new information and communication technologies in all areas of social life and activity, the level of production and consumption by society of information products and services.

${ }^{5}$ Karklins, R. (2005). The System Made Me Do It: Corruption in Post-communist Societies. Armonk, New York: M.E. Sharpe, p. 16-17.

${ }^{6}$ Поляков М.М. Европейский опыт борьбы с коррупцией органами исполнительной власти и прокуратуры. Available from https://cyberleninka.ru/article/n/evropeyskiy-opyt-borbys-korruptsiey-organami-ispolnitelnoy-vlasti-i-prokuratury. 
Apparent change of attitude to information resources and the expansion of production and application of information capabilities to enhance human potential and its development in many district and boards. Such opportunities in modern society are provided by the e-government system. Is the Ukrainian population ready to take advantage of electronic services that are designed to greatly facilitate the lives of citizens?

An analysis of the situation in Ukraine shows that there are factors that impede the approximation of e-government to the needs of people. First of all, this is a low level of Internetization of the population, especially in rural areas. According to a study conducted by Factum Group, a research company commissioned by the Internet Association of Ukraine, the number of regular Internet users by the end of Q3 2019 increased by 7\% to 22.96 million, the share of Internet users is $71 \%$ (22.96 million), 65\% have internet at home. The most active Internet users, of course, are young people. According to the study, "almost the entire population of Ukraine under the age of 35 are Internet users" 7 .

Thus, people of respectable age who do not have the skills to use information and communication technologies cannot use the services of egovernment. Electronic receptions, which were conceived to facilitate access to the e-government system, were never created. It became clear that in conditions of total underfunding it is impossible to organize the work of specialists in advising citizens and servicing equipment. Yes, there are Internet clubs, Internet cafes, but as practice has shown, their audience is exclusively young people spending their leisure time there.

The fact that in recent years the number of Internet users in Ukraine has increased by $7 \%$ is positive. However, this does not mean an increase in the number of users of the e-government system. We have to admit that the social demand for electronic services is still low in Ukrainian society, and this is one of the serious obstacles to the development of electronic government. The reasons are different. Some citizens doubt the availability and quality of electronic services. Many citizens worry about the confidentiality and secrecy of their personal data. And these fears are not unfounded. As you know, in Ukraine you can purchase any electronic database with personal data, including those for which law enforcement agencies are responsible. Credit scammers take money from credit cards and steal confidential information. Naturally, all this is done by people, not the Internet, but as a result of this, citizens are distrustful of new technologies.

We can not ignore that, thanks to information and communication technologies, we cannot ignore that, thanks to IT, the government is gaining new opportunities for control over society. And the state does not necessarily become

${ }^{7}$ Количество пользователей интернетом в Украине выросло на 7\% - исследование. Available from https://www.epravda.com.ua/rus/news/2019/10/11/652498/. 
more open. It cannot be argued that the unified government bases created in many countries of the world with a huge amount of confidential and personal information about each individual person will be used only to improve the quality of public services. So, as it would have to be in a democratic environment with the control of society over the activities of the authorities. For example, in the United States, Internet policy has been heavily criticized. Namely, various organizations for the protection of civil rights and freedoms of consumers express concern about the increase in the number of cases of unauthorized use of personal data. The wide, almost unlimited possibilities of modern computer technologies for the exchange, integration and classification of information make it possible, without much effort, to create an "information portrait" of the individual, allowing public and private institutions to use the information in their own interests. This circumstance, known to man, has a negative effect on his self-consciousness, causing the feeling of being under the close attention of these structures. According to Western scholars S. Cunningham and A. Porter, "databases compiled on people can lead to a person's loss of individual, private life and personal freedom, and provide an opportunity for discrimination on an unprecedented scale" ${ }^{\text {. }}$

It should also be borne in mind that not all citizens agree to learn how to use information technology. After all, this requires certain properties from a potential user, first of all, readiness to improve education. Only in this way is it possible to acquire the necessary skills for communicating with e-government.

The paradox is that with a large number of higher education institutions, the level of computer literacy among the Ukrainian population is low.

A major role in the process of preparing citizens for life in the information society is played by the state. C 2001 in the European Union, the eCitizen standard of the European Computer Driving License (ECDL) is being introduced as the official computer literacy standard. Based on this standard, the "Electronic Citizen" program is being implemented - the world's leading project for training beginners in personal computer skills. It would be advisable if Ukraine became an active participant in this program.

Recently it became known about the new program of the Ministry of Digital Transformation of Ukraine, within the framework of which it is planned to train 6 million. Ukrainians in three years of digital literacy. The program is implemented in the format of the series, the creation of which will be attended by famous Ukrainians. As Minister Mikhail Fedorov stated on his page in the FB, "There are projects that are changing the country. Today we are launching an online educational platform for training digital skills of Ukrainians. Everyone should have the right to free education in this area.

${ }^{8}$ Каннингэм, С. (2000). Сетевые средства связи: двенадцать способов изменить нашу жизнь. Впереди XX1 век. Антология современной классической прогностики. М.: Academia. C. 96. 
Subsequently, this will become our national competitive advantage. It will be possible to study in any computerized library according to our program" ${ }^{9}$.

It follows that the creation of the program was preceded by a study that showed that " $53.5 \%$ of Ukrainians are below the average level in digital literacy. $15.1 \%$ of Ukrainians do not possess digital skills, and $37.9 \%$ of citizens have a low level of digital skills. The most vulnerable segment on the Internet is young people under 16 years old and people over 60 years old.”

Begin to educate an "electronic citizen" should be from school. Computer science should not be taught at school formally, as is happening now, when students are sometimes more familiar with information technology than a teacher. And at a high level - a professional teacher, a modern computer, the latest techniques and the required number of hours. To this end, changes to the school curriculum in computer science are needed. Therefore, it is logical that students are one of the target audiences of this program. The motivation for learning for schoolchildren and students is employment and the prospect of realization in the profession.

Also, the initiators of the implementation of this program consider it necessary to educate parents of children from three years of age and older who use electronic devices. It is estimated that parents will need special knowledge in order to protect their children from the negative impact of the Internet.

The next group is entrepreneurs who will be taught online security, digital marketing, etc. With a middle age, men in this group are 45 years old, women are 43 years old.

This is followed by an age group of 30 to 60 years. These are teachers, doctors, public servants, specialists from various directions of the private sector. They all need digital skills to enhance their competitiveness.

A particular problem is the teaching of computer literacy for older and older people. For this, a special state program is needed, thanks to which people of this age category will gain computer skills and the ability to work with information from the public services portal. This will help them maintain communication with loved ones, find the right information, and use administrative and social online services.

Another reason for computer illiteracy is the low level of material wellbeing of Ukrainian citizens. Ukrainian salaries and pensions do not match the prices of modern information gadgets. So, according to Valeria Ionan, Deputy Minister of Digital Transformation on European Integration, based on the results of a sociological study, in Ukraine $51 \%$ of families do not have a single computer, and $49.4 \%$ do not have a single laptop ${ }^{10}$.

${ }^{9}$ В Украине запускают сериал о цифровой грамотности. Available from: https://lb.ua/news/2020/01/21/447692_ukraine_zapuskayut_serial_tsifrovoy.html.

10 В Украине 51\% семей не имеют ни одного компьютера. Available from: https://news.finance.ua/ru/news/-/462589/v-ukraine-51-semej-ne-imeyut-ni-odnogo-kompyuteraissledovaniya. 
Interesting results were obtained in the course of study I influence the development of electronic public services and the level of corruption in the EU and in countries outside the EU. D. Lupu and K.G. Lazar suggested that citizens with remote access can use information and communication technologies to monitor the activities of state and municipal authorities, which will result in a reduction in corruption. They proved that a $1 \%$ increase in the e-government index could lead to a $6.7 \%$ reduction in corruption for EU countries and $6.3 \%$ for non-EU countries ${ }^{11}$.

\section{Willingness of officials to implement the e-government system}

Became popular, in the context of the election of President of Ukraine Vladimir Zelensky, the series "Servant of the People" got its name for a reason. The same goes for the new political party, which received in the 2019 parliamentary elections, stunning support from Ukrainian citizens. The screenwriters farsightedly focused on the social request of citizens for a democratic political system in which the state is a service organization whose employees provide public services to people. However, few people recall that for the first time the term "servant of the people" was voiced by Stalin on December 11, 1937 during a speech in one of the Moscow constituencies named in his honor.

New opportunities in the fight against corruption have appeared in the information society. International practice has shown that information technology allows, firstly, to reduce the role of the human factor in the process of managerial decision-making, and secondly, to more effectively involve citizens who previously preferred to remain critics of corruption rather than fighters against it in anti-corruption processes.

The term "digitalization" with a light hand of the new Ukrainian government became the word of the year according to the dictionary of the modern Ukrainian language and slang "Mislovo". According to the authors of the Dictionary, digitalization is "changes in all spheres of public life associated with the use of digital technologies". They call the phrase "digital transformation" the Ukrainian counterpart" ${ }^{12}$.

Speaking about the introduction of digitalization in all spheres of activity of Ukrainian society, the new government implies primarily electronic document management, digital signatures, open and accessible databases, and much more. The main goal is to liberate Ukrainians from paper bureaucracy,

${ }^{11}$ Lupu D., Lazar C.G. Influence of e-government on the level of corruption in some EU and non-EU states. Available from https://www.sciencedirect.com/science/article/pii/ S2212567115000854.

12 Неожиданно: в Украине назвали слово года, и это не «Зе» и не «монобольшниство». Available from https://fakty.ua/329170-ne-ze-i-ne-turborezhim-v-ukrainenazvali-slovo-goda. 
endless queues in state bodies and it has become a tradition for them to confirm the saying "you will not smear - you will not go".

Thus, the technical means at the disposal of the subjects play an important role in the implementation of information relations in politics, which makes us talk about the technical level of information and communication processes. It is the quality of technology that now provides the interaction of power and society.

It should be noted that attempts to introduce technologies of a "transparent office" in Ukraine have already been made. On March 12010 the order of the Cabinet of Ministers of Ukraine No. 360-r was issued on the implementation of a pilot project for the introduction of e-government technologies. At this disposal, the Ukrainian government agreed with the proposal of the State Informatization Committee on implementation in 2010 a pilot project on the introduction of e-government technologies in government bodies and local self-government bodies with the aim of creating the legal, scientific, technical, financial and economic conditions for the development of the information society.

The main objective of the pilot project was to identify a mechanism for solving problems associated with the functioning of electronic document management; ensuring the permanent storage of electronic documents and other electronic information resources, as well as information protection; development of formats of typical electronic documents of state authorities and local authorities; preparation of temporary regulations for electronic document management in executive bodies.

In 2013 the Government of Ukraine announced the opening of socalled "transparent offices" in all regions of Ukraine, which were supposed to provide citizens with administrative and social services. In 2014 the State Agency for E-Government Issues was created. Ukrainians were promised a new quality of work with citizens on the basis of the Unified Information and Analytical System of Social Protection of the Population. Also, as now, it was assumed the disappearance of paperwork, increasing the efficiency of use of funds. And, of course, minimizing the risk of abuse by officials ${ }^{13}$.

In 2016 the development of e-government has once again become one of the objectives of the Government's program of activities. However, the lack of a state strategy, the imperfection of the legislative score, and the lack of political will led to the result that we, alas, know. People still go from office to office for the necessary information, patiently stand in long hours, and.... continue to pay bribes.

In the UN ranking on the development of e-government in the world in 2018. Ukraine took 82 place. Compared with 2014 it is 5 points higher.

${ }^{13}$ Арбузов анонсировал создание «прозрачных офисов» во всех областях Украины. Available from http://podrobnosti.ua/power/2013/07/30/920480.html. 
However, there is no need to speak about the significant progress that every Ukrainian has felt on himself.

In this context, Dmitry Dubilet urgently called for combating corruption with the help of technology. By the way, Dmitry Dubilet is one of the few members of the government whose work results can be seen firsthand. It was he, together with a group of activists, who created the iGov portal, on which 321 admin services are already available. Thanks to the portal, the citizen reduced the number of his visits to officials. Although at least once it is necessary to appear to officials, however, no doubt, progress has been made. At the same time, this fact weakens the effectiveness of this system. To receive a bribe, an official needs only one visit from a client. Moreover, where are the guarantees that even when a personal meeting between the official and the client is not needed, the official will not hide it and call the client?

Another attempt to introduce electronic services in Ukraine was made recently in 2018.

The purpose of the Trembita information system is to provide government agencies with the opportunity to exchange electronic registries in real time. Working to improve this system, Ukrainian experts rely on the experience of Estonia, which is very progressive in the development of the e-government system. Estonian IT-system « the X-Road General Description " allows you to receive e-service from anywhere in the world within minutes. Thus, saving money and time for citizens and officials, eliminating the causes of corruption. According to reports, in 2018 the system processed almost 1 billion requests, and in February 2019 - 104 million requests. In 2018, X-Road saved 1,407 working years or 12.3 million working hours for Estonian citizens. In total, 2,595 public services are available online in Estonia. Every year an Estonian citizen uses 100-120 electronic public services and every year, electronic public services save an Estonian citizen 10 days of life ${ }^{14}$.

In our opinion, the experience of Singapore is also useful for Ukraine, which during the creation of e-government was guided by the principle "Any public service, if possible, should be provided in electronic form". What Singapore has managed to achieve today is absolutely necessary in Ukraine: transparency of the process of providing public services, increasing the efficiency of public administration, reducing corruption, improving communication between the state and society. An interesting point for understanding the Singaporean e-government system is the fact that if a citizen comes to a government agency for a service that can be obtained electronically, he can be fined.

${ }^{14}$ Как будет выглядеть "цифровая" Украина: репортаж из Эстонии. Available from https://www.epravda.com.ua/rus/publications/2019/03/18/646173/. 
Adopted Law of Ukraine "On Electronic Digital Signature" dated May 22, 2003. (Law on EDS), which is the basis of electronic document management, the Law of Ukraine "On Payment Systems and Money Transfer in Ukraine" dated April 5, 2001. (Law on Payment Systems) and the Law of Ukraine "On Electronic Documents and Electronic Document Management" dated May 22, 2003. (The Law on Electronic Documents) gave hope that the formal exchange of information between users and government bodies would be the beginning of effective promotion of Ukraine to electronic government, that the main form of use by state bodies of modern communication technologies would be the integration of information systems of individual departments into a single network. However, so far this has not happened. The main form of use by state bodies of modern communication technologies will be the integration of information systems of individual departments into a single network.

In Ukraine, the conditions for the full launch of the electronic government are still being created. Sometimes the success of this process depends on the goodwill of the ministries. And the situation is like that, or all, or nobody. So that, if, for example, the Ministry of Education or Health does not connect to the system of electronic services, the efforts of others can become meaningless.

One of the reasons for this situation is the official's lack of interest in introducing informational innovations into the management process. After all, innovation contributes to a reduction in the budget, a reduction in personnel and, accordingly, a reduction in licensing functions.

On this occasion, the Ukrainian researcher N. Kruk rightly writes that "the reasons for the resistance of officials to the introduction of information transparency are: the discrepancy between their interests and the interests of society; lack of motivation due to a lack of understanding of the goals of modernizing state power; loss of power and influence, persisting due to the existing monopoly on information; decrease in official status; insufficient level of technical competence, etc.” 15

If 5-10 years ago in Ukraine there was an urgent problem of training public servants open for the implementation of information and communication technologies, since there was great resistance to the conservative part of the state apparatus. Today we are faced with a new problem, new officials who have replaced the previous ones have a low level of competence and a lack of experience in solving state problems.

An increasing number of websites of various government bodies, party structures, and numerous international non-governmental organizations appear

15 Крук Н. В. (2014). Інформаційна відкритість як принцип діяльності органів державної влади, дис. ... канд. політ. наук. 23.00.02 - політичні інститути та процеси. Одеса, 178 с. 
on the Web, containing a variety of information that significantly increases the political awareness of the masses. A variety of government publications that previously were available to only a few are becoming publicly available. The Internet is stimulating the emergence of new, effective mechanisms for political mobilization of citizens. Without exaggeration, it can be considered a means of rather prompt organization and coordination of actions of political like-minded people who are supporters of non-traditional social movements.

As a result of monitoring of 65 official websites of the central and 25 websites of local authorities of Ukraine, conducted by the State Committee for Television and Radio Broadcasting in the first half of 2019 official websites of the Ministry of Agrarian Policy, the Ministry of Infrastructure, the Ministry of Information Policy, the State Service for Medicines and Drug Control, the State Labor Service, the State Emergency Service, and the Administration of the State Border Service of Ukraine are recognized the best.

The official websites of the Khmelnitsky, Volyn, Poltava, Zaporizhzhya, Dnipropetrovsk, Kharkiv, Zhytomyr, Ivano-Frankivsk, Transcarpathian, Rivne, Kherson and Chernihiv regional state administrations are identified as leaders in the rating among local executive authorities облгосадминистраций ${ }^{16}$.

Most sites use information level modes (providing direct information about state (administrative) services and one-way interaction (the user can receive an electronic form of a document). At the same time, two-way interaction modes are not yet widespread (the electronic form of a document cannot be processed, including identification) and transactions.

All central executive bodies provide information services at the level of informing about the service: name of service; administrative authority that provides the service; regulatory documents that govern the provision of services; consulting materials.

It is important to remember that not only anti-corruption, but also corrupt officials who successfully use electronic services for criminal purposes have learned new information technologies.

The well-known human rights organization Transparency International recommended to Ukraine in 2019 the following anti-corruption measures: restart NAPK; implement proper automatic verification of declarations and monitoring the standard of living of declarants; ensure the effective operation of the beneficiary registry; continue public procurement reform; corporatize and privatize state-owned enterprises; strengthen control over the financing of political parties (Corruption Perception Rating...). Two of these recommendations, in particular, automatic verification of declarations and public

\footnotetext{
${ }^{16}$ Назвали лучшие сайты органов исполнительной власти. Available from: https://www.ukrinform.ru/rubric-society/2733826-nazvali-lucsie-sajty-organov-ispolnitelnojvlasti.html.
} 
procurement reform, are directly dependent on information technology. It would seem that openness and automation will help narrow the field for corruption. However, in practice, it turned out that new technologies are not a panacea in the fight against corruption. A Declaration checked selectively, and public procurement organized by the scheme to circumvent anti-corruption Prozorro benefits system, which aims to transparency in government procurement and thus decrease the risk of corruption. To corruption officials easily found ways to conduct their schemes through this system. An analysis of the tenders passed through Prozorro shows that the most profitable of them were held with one participant. And this allows us to conclude a preliminary conspiracy ${ }^{17}$.

\section{CONCLUSIONS}

The foregoing allows us to draw some conclusions. The rapid development of information tools and technologies in the twentieth century has made information a direct engine of progress. In fact, we are witnessing the formation of a new, more effective form of self-organizing civil society. Civil society and the IT sector in Western countries became the first active users of information and communication technologies. With oday they derive great benefits from the use of digital opportunities to overcome corruption. Will Ukraine go this way? Obviously, yes, since today there is no other choice, except for how to actively use new information technologies and respond quickly to the challenges of the information society.

E-government is the use of information and communication technologies to transform government in order to make it more accessible to citizens, more efficient and more accountable. Thus, e-government does not mean a simple increase in the number of computers among officials. We are talking about global changes affecting the relationship between public servants and citizens.

E-government in Ukraine is possible under certain conditions, in particular, the readiness of state authorities and the willingness of citizens to become users of e-government.

State readiness implies orientation towards citizens, bridging the digital divide, professionalism and computer literacy of officials, effective organization, and, of course, technical infrastructure. As many public services as possible should be provided in electronic form, which is why it is imperative to combine the websites of ministries and departments into a single information space.

Citizens' readiness includes computer literacy and a psychological attitude, without which they cannot take advantage of the benefits of the information society.

17 Prozorro: преодоление коррупции или выкручивание рук администраторам? Available from https://finstat.info/2018/04/prozorro-preodolenie-korruptsii-ili-vyikruchivanieruk-administratoram.html. 
The availability of information on the activities of authorities, political processes and events, contributes to the openness of political institutions, the involvement of interested sectors of society in the public administration process, which allows us to hope for the expansion of the conventional political participation of civil society, building a mobile dialogue in the context of mass consultations and coordination of various positions of the participants in the interaction.

\section{SUMMARY}

The article discusses the role of digitalization in the fight against corruption in Ukraine. It is noted that digitalization is an important, but not the only factor that positively affects the reduction of corruption. It is shown that information technology is not a panacea for corruption, so not only anticorruption, but corrupt officials who successfully overcome electronic traps get new opportunities. In s fissile few basic factors influencing the efficiency of the launch of e-government in Ukraine. This willingness of the public and officials to the introduction of e electrons government. The experience of Estonia and Singapore in terms of its usefulness for Ukraine is considered.

\section{REFERENCES}

1. Арбузов анонсировал создание «прозрачных офисов» во всех областях Украины. Available from http://podrobnosti.ua/power/2013/ 07/30/920480.html.

2. Борьба с коррупцией - зарубежный опыт: от Швеции до Сингапура. Available from http://argumentua.com/stati/borba-s-korruptsieizarubezhnyi-opyt-ot-shvetsii-do-singapura.

3. В Украине запускают сериал о цифровой грамотности. Available from: https://lb.ua/news/2020/01/21/447692_ukraine_zapuskayut_serial_ tsifrovoy.html.

4. В Украине 51\% семей не имеют ни одного компьютера. Режим доступа: https://news.finance.ua/ru/news/-/462589/v-ukraine-51-semej-neimeyut-ni-odnogo-kompyutera-issledovaniya.

5. Если власть не прибегнет к насилию: эксперты рассказали, готовы ли украинцы выходить на акции протеста. Available from: https://styler.rbc.ua/rus/zhizn/esli-vlast-pribegnet-nasiliyu-eksperty-rasskazali1536955375.html.

6. Каждый третий в Украине готов выйти на улицу из-за коррупции. Available from: http://www.pravda.com.ua/rus/news/2013/07/ 9/6993866/.

7. Как будет выглядеть «цифровая» Украина: репортаж из Эстонии Режим доступа: https://www.epravda.com.ua/rus/publications/2019/03/18/ $646173 /$. 
8. Каннингэм, С. (2000). Сетевые средства связи: двенадцать способов изменить нашу жизнь. Впереди XX1 век. Антология современной классической прогностики. М.: Academia, 480 c.

9. Количество пользователей Интернетом в Украине выросло на 7\% - исследование. Available from: https://www.epravda.com.ua/rus/ news/2019/10/11/652498/.

10. Крук Н. В. (2014). Інформаційна відкритість як принцип діяльності органів державної влади, дис. ... канд. політ. наук. 23.00.02 політичні інститути та процеси. Одеса, 178 с.

11. Назвали лучшие сайты органов исполнительной власти. Available from: https://www.ukrinform.ru/rubric-society/2733826-nazvalilucsie-sajty-organov-ispolnitelnoj-vlasti.html.

12. Неожиданно: в Украине назвали слово года, и это не «Зе»и и не «монобольшниство». Available from: https://fakty.ua/329170-ne-ze-i-neturborezhim-v-ukraine-nazvali-slovo-goda.

13. Поляков М.M. Европейский опыт борьбы с коррупцией органами исполнительной власти и прокуратуры. Available from: https://cyberleninka.ru/article/n/evropeyskiy-opyt-borby-s-korruptsieyorganami-ispolnitelnoy-vlasti-i-prokuratury.

14. Рейтинг восприятия коррупции: Украина поднялась выше, но до сих пор отстает от соседей. Available from: https://www.bbc.com/ ukrainian/news-russian-47041703.

15. Karklins, R. (2005). The System Made Me Do It: Corruption in Post-communist Societies. Armonk, New York: M.E. Sharpe, 219 p.

16. Lupu D., Lazar C.G. Influence of e-government on the level of corruption in some EU and non-EU states. Available from: https://www.sciencedirect.com/science/article/pii/S2212567115000854.

17. Prozorro: преодоление коррупции или выкручивание рук администраторам? Available from: https://finstat.info/2018/04/prozorropreodolenie-korruptsii-ili-vyikruchivanie-ruk-administratoram.html.

\section{Information about the author:} Silenko A. A., Doctor of Political Sciences, Professor, Vice-Rector, Odessa National Academy communication of A. S. Popov 1, Cuznechna str., Odessa, 65000, Ukraine 
Publishing house "Liha-Pres"

9 Kastelivka str., Lviv, 79012, Ukraine 44 Lubicka str., Torun, 87-100, Poland

Printed by the publishing house "Liha-Pres"

Passed for printing: October 25, 2019.

A run of 150 copies. 